
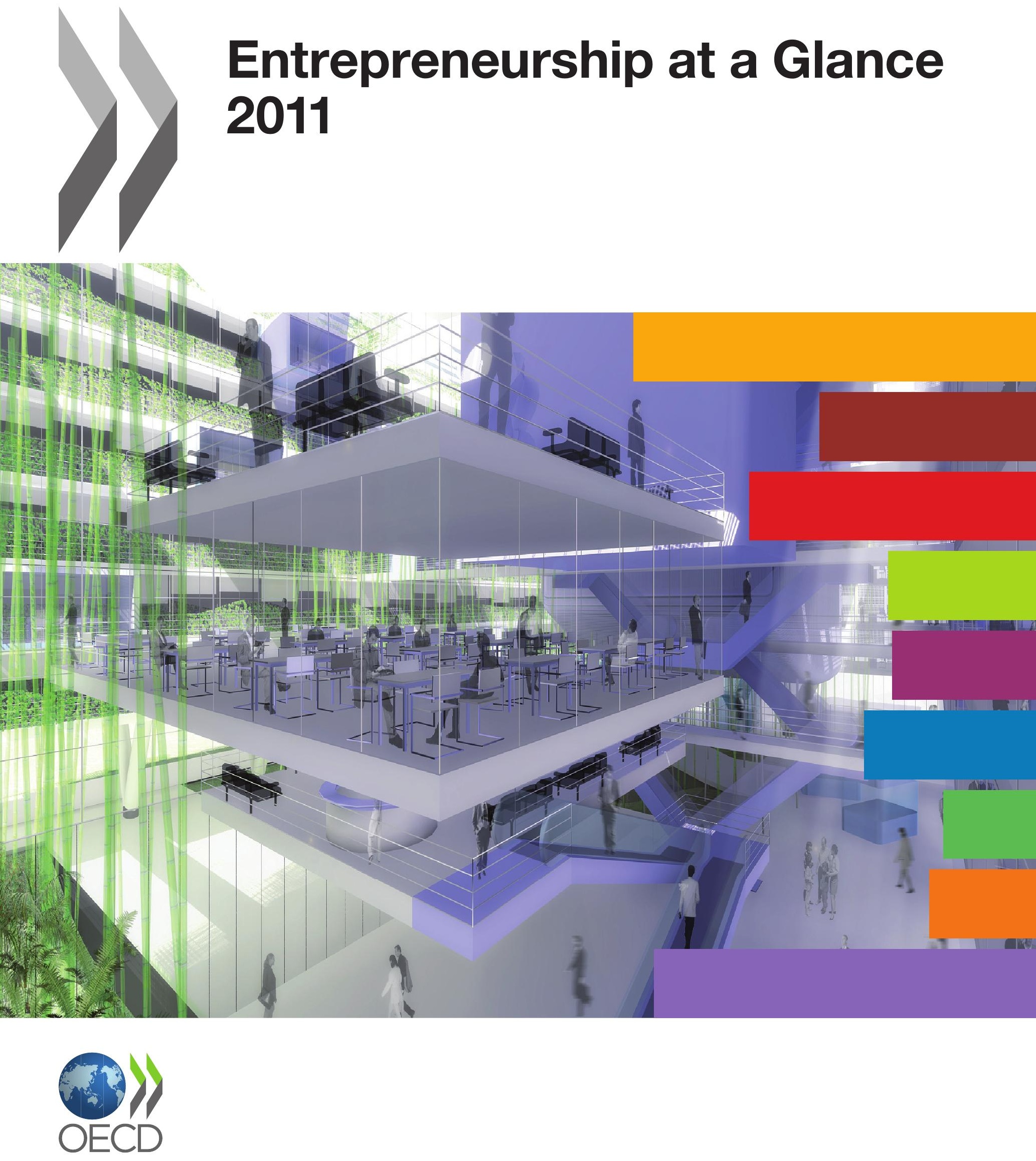



\section{Entrepreneurship at a Glance 2011}


This work is published on the responsibility of the Secretary-General of the OECD. The opinions expressed and arguments employed herein do not necessarily reflect the official views of the Organisation or of the governments of its member countries.

\author{
Please cite this publication as: \\ OECD (2011), Entrepreneurship at a Glance 2011, OECD Publishing. \\ http://dx.doi.org/10.1787/9789264097711-en
}

ISBN 978-92-64-09576-2 (print)

ISBN 978-92-64-09771-1 (PDF)

The statistical data for Israel are supplied by and under the responsibility of the relevant Israeli authorities. The use of such data by the OECD is without prejudice to the status of the Golan Heights, East Jerusalem and Israeli settlements in the West Bank under the terms of international law.

\title{
Photo credits:
}

Cover: @ Jacques Ferrier architectures/image Ferrier Production. "Concept Office, immeuble de bureaux prototype à haute qualité environnementale conçu par Jacques Ferrier Architectures en partenariat avec EDF".

Chapters : ๑ Philippe Mairesse / Devizu.

Corrigenda to OECD publications may be found on line at: www.oecd.org/publishing/corrigenda.

(c) OECD 2011

You can copy, download or print OECD content for your own use, and you can include excerpts from OECD publications, databases and multimedia products in your own documents, presentations, blogs, websites and teaching materials, provided that suitable acknowledgment of OECD as source and copyright owner is given. All requests for public or commercial use and translation rights should be submitted to rights@oecd.org. Requests for permission to photocopy portions of this material for public or commercial use shall be addressed directly to the Copyright Clearance Center (CCC) at info@copyright.com or the Centre français d'exploitation du droit de copie (CFC) at contact@cfcopies.com. 


\section{Foreword}

$\mathrm{E}$ Entrepreneurship at a Glance is a new publication that presents key indicators on entrepreneurship. Until recently, most entrepreneurship research relied on ad hoc data compilations developed to support specific projects and virtually no official statistics on the subject existed. The collection of harmonised indicators presented in this publication is the result of the OECD-Eurostat Entrepreneurship Indicators Programme (EIP). The programme, started in 2006, is the first attempt to compile and publish international data on entrepreneurship from official government statistical sources. Indeed, to meet the challenge of providing new entrepreneurship indicators, while minimising costs for national statistical offices and burden on business, the programme focuses attention on exploiting existing sources of data instead of developing new business surveys.

Entrepreneurship is defined by the EIP as the phenomenon associated with entrepreneurial activity, which is the enterprising human action in pursuit of the generation of value, through the creation or expansion of economic activity, by identifying and exploiting new products, processes or markets. In this sense, entrepreneurship is a phenomenon that manifests itself throughout the economy and in many different forms with many different outcomes, and these outcomes are not always related to the creation of financial wealth; for example, they may be related to increasing employment, tackling inequalities, or indeed, increasingly, environmental issues. The challenge of the EIP is to improve the understanding of these multiple manifestations. The programme recognises that no single indicator can ever adequately cover entrepreneurship, and it has therefore developed a set of measures that each captures a different aspect or different type of entrepreneurship; these measures are referred to as EIP indicators of entrepreneurial performance. There are currently some 20 performance indicators and 25 countries covered in the EIP; extending the coverage to more indicators and countries is one of the main objectives of the programme.

The EIP takes a comprehensive approach to the measurement of entrepreneurship by looking not only at the manifestation of the entrepreneurial phenomenon but also at the factors that influence it. These factors range from the market conditions to the regulatory framework, to the culture or the conditions of access to finance. While some areas of determinants lend themselves more easily to measurement (for instance, the existence and restrictiveness of anti-trust law or the administrative costs to set-up a new business in a country), for other determinants the difficulty resides in finding suitable measures (e.g. venture capital and angel capital) and/or in comprehending the exact nature of their relationship with entrepreneurship (e.g. culture). The EIP aims to contribute to advance research on the less understood, less measurable determinants of entrepreneurship.

The publication is divided into two parts. The first presents conceptual and methodological issues related to the measurement of entrepreneurship and its determinants. In this first edition of Entrepreneurship at a Glance two topics are addressed: the quality and international comparability of entrepreneurship indicators computed from statistical business registers, and the operationalisation of the concept of green entrepreneurship for the purpose of measurement. Future editions of the publication will report on progress in measuring specific types of entrepreneurship, such as high-growth enterprises and social entrepreneurship, or specific determinants, for example entrepreneurial culture and capabilities. The choice of themes reflects the ambitions of the EIP to establish sound and comparable measures of entrepreneurship and its determinants. 
The second part of the publication is broken down into eight sections, covering mainly indicators of entrepreneurial performance but also presenting a selection of indicators of determinants. The initial sections focus on structural data of the enterprise population (1) and on indicators of business demography (2 to 4). Timely indicators of entrepreneurship, which provide updated, although not fully comparable information on enterprise dynamics, are presented in a separate section (5). Section 6 looks at the gender dimension of entrepreneurship, while Section 7 provides examples of indicators for migrants entrepreneurs. The final Section (8) contains a selection of indicators of entrepreneurial determinants; these are drawn from a number of international sources.

The OECD-Eurostat Entrepreneurship Indicators Programme has benefited from generous sponsorship by the Ewing Marion Kauffman Foundation of the United States and the International Consortium for Entrepreneurship (ICE), and from the guidance and support of the EIP Steering Group, whose members include:

\begin{tabular}{|c|c|c|}
\hline Australia & Richard Seymour & University of Sydney \\
\hline Brazil & $\begin{array}{l}\text { Cristiano Santos } \\
\text { Amisha Miller }\end{array}$ & $\begin{array}{l}\text { IBGE } \\
\text { Endeavor }\end{array}$ \\
\hline Canada & $\begin{array}{l}\text { Denis Martel } \\
\text { Sonja Djukic }\end{array}$ & $\begin{array}{l}\text { Industry Canada } \\
\text { Industry Canada }\end{array}$ \\
\hline Denmark & $\begin{array}{l}\text { Anders Hoffman (Chair) } \\
\text { Dorte Hoeg Koch } \\
\text { Peter Bøegh Nielsen }\end{array}$ & $\begin{array}{l}\text { Danish Ministry of Economic and Business Affairs } \\
\text { Danish Ministry of Economic and Business Affairs } \\
\text { Statistics Denmark }\end{array}$ \\
\hline Finland & Marko Tuomiaro & Statistics Finland \\
\hline Hungary & Zoltan Roman & Academy of Sciences \\
\hline Italy & Caterina Viviano & ISTAT \\
\hline Japan & $\begin{array}{l}\text { Mikio Suga } \\
\text { Hideo Umezawa }\end{array}$ & $\begin{array}{l}\text { Tokyo International University } \\
\text { Statistics Japan }\end{array}$ \\
\hline Portugal & Paula Bordelo & Statistics Portugal \\
\hline Sweden & Håkan Alm & Ministry of Enterprise, Energy and Communications \\
\hline United Kingdom & Karen Grierson & Department for Business, Innovation and Skills \\
\hline United States & $\begin{array}{l}\text { Rick Clayton (Co-Chair) } \\
\text { David Talan } \\
\text { Ron Jarmin } \\
\text { Javier Miranda }\end{array}$ & $\begin{array}{l}\text { Bureau of Labor Statistics } \\
\text { Bureau of Labor Statistics } \\
\text { US Census Bureau } \\
\text { US Census Bureau }\end{array}$ \\
\hline Kauffman Foundation & E.J. Reedy & \\
\hline European Commission & Ludger Odenthal & DG Enterprise and Industry \\
\hline Eurostat & $\begin{array}{l}\text { Merja Hult } \\
\text { Manfred Schmiemann } \\
\text { Aleksandra Stawinska }\end{array}$ & Structural Business Statistics \\
\hline OECD & $\begin{array}{l}\text { Benoît Arnaud } \\
\text { Tim Davis } \\
\text { Dominique Guellec } \\
\text { Mariarosa Lunati }\end{array}$ & Statistics Directorate \\
\hline
\end{tabular}

Mariarosa Lunati co-ordinated the production of this publication. Benoit Arnaud, Michela Gamba, Eric Gonnard, Emmanuelle Guidetti, Alexandros Ragoussis and Gueram Sargsyan had overall responsibility for technical work on the manuscript. The publication benefited from comments by Nadim Ahmad, Dominique Guellec and Paul Schreyer.

Martine Durand

Chief Statistician and Director of the OECD Statistics Directorate

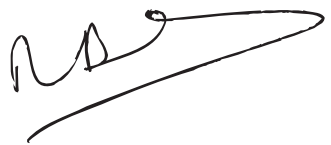




\section{Table of Contents}

Reader's Guide

\section{Part I \\ MEASURING ENTREPRENEURSHIP}

Chapter 1. Entrepreneurship Indicators and Business Registers:

The Importance of International Comparability . . . . . . . . . . 13

1.1. Background ....................................... 14

1.2. The importance of statistical business registers in achieving comparability . $\quad 16$

1.3. Developing timely indicators of entrepreneurship $\ldots \ldots \ldots \ldots \ldots \ldots \ldots 20$

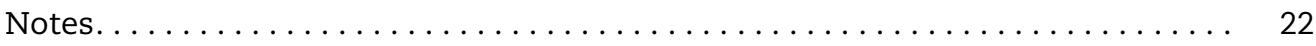

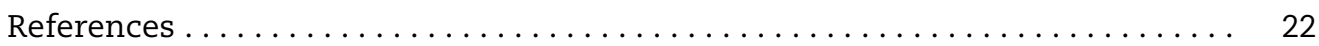

Chapter 2. Measuring Green Entrepreneurship................... 23

2.1. Definitions and measures of green entrepreneurship ............... 24

2.2. "Green" in the context of entrepreneurship ................. 28

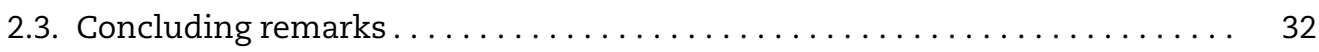

Notes.................................... 32

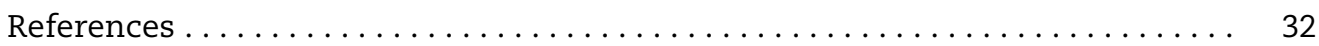

Annex I.A. Example of Environmental Sectors ................... 34

\section{Part II \\ ENTREPRENEURSHIP INDICATORS}

Structural Indicators on the Enterprise Population $\ldots \ldots \ldots \ldots \ldots \ldots \ldots \ldots . \ldots 1$

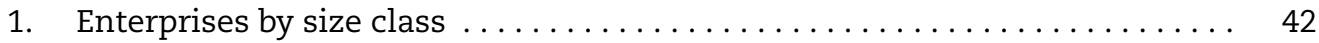

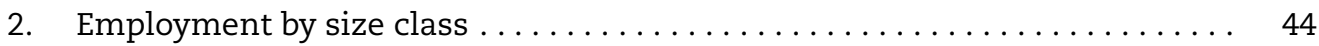

3. Value added by size class. . . . . . . . . . . . . . . . . . . . 46

4. Exports by size class . . . . . . . . . . . . . . . . . . 48

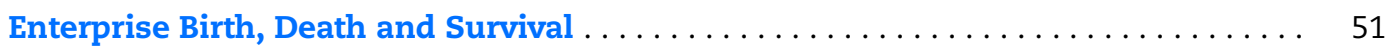

5. Birth rate of employer enterprises . . . . . . . . . . . . . . . . . 52

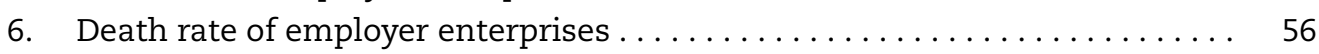

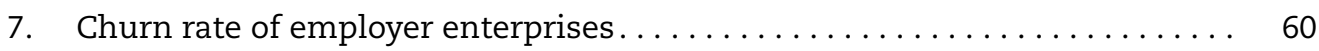

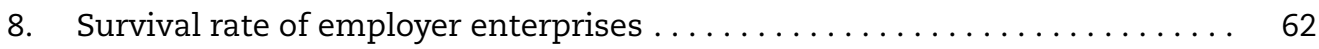


Employment Creation and Destruction $\ldots \ldots \ldots \ldots \ldots \ldots \ldots \ldots \ldots \ldots$

9. Employment creation and destruction by employer enterprise births and deaths ........................... 68

10. Employment creation and destruction in surviving enterprises . . . . . . . 70

Enterprise Growth $\ldots \ldots \ldots \ldots \ldots \ldots \ldots \ldots \ldots \ldots \ldots \ldots \ldots \ldots \ldots$

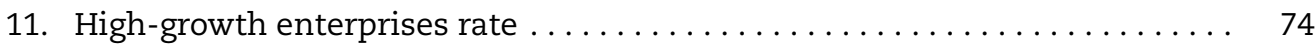

12. Gazelles rate $\ldots \ldots \ldots \ldots \ldots \ldots \ldots \ldots \ldots \ldots \ldots \ldots \ldots \ldots \ldots$

13. Distribution of enterprises by growth rate $\ldots \ldots \ldots \ldots \ldots \ldots \ldots$

Timely Indicators of Entrepreneurship. . . . . . . . . . . . . 81

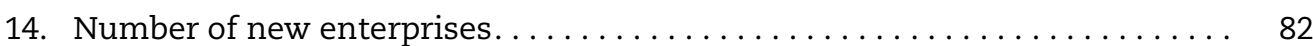

15. Distribution of new enterprises by industrial activity. . . . . . . . . 84

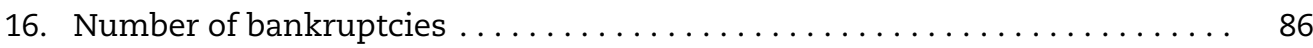

Women Entrepreneurship $\ldots \ldots \ldots \ldots \ldots \ldots \ldots \ldots \ldots \ldots \ldots \ldots \ldots \ldots$

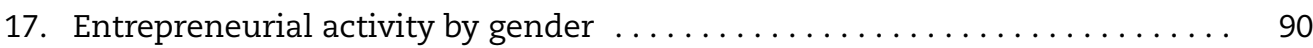

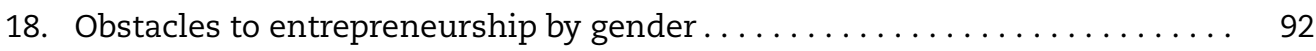

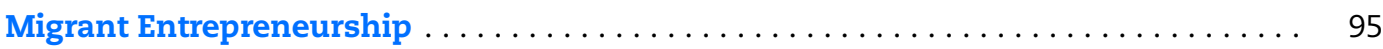

19. Share of foreign enterprise owners $\ldots \ldots \ldots \ldots \ldots \ldots \ldots \ldots \ldots \ldots$

Determinants of Entrepreneurship: Selected Indicators . . . . . . . . . . . 99

20. Regulatory framework: Starting a business . . . . . . . . . . . . . . . 100

21. Access to finance: Venture capital . . . . . . . . . . . . . . . . . . . . 102

22. Culture: The image of entrepreneurs. . . . . . . . . . . . . . . . . . . . . . . . 104

Annex II.A. Sources of Data on Timely Indicators of Entrepreneurship . . . . . . . . 107

Annex II.B. List of Indicators of Entrepreneurial Determinants . . . . . . . . . . . 110

\section{This book has...}

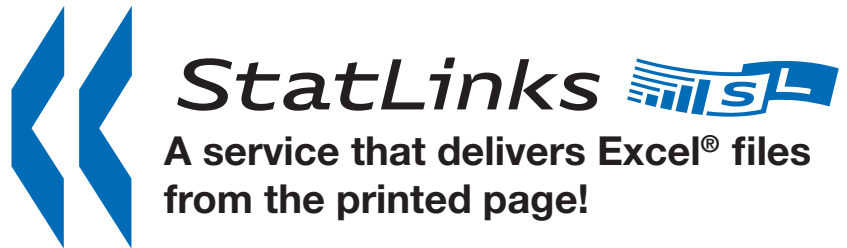

Look for the StatLinks at the bottom right-hand corner of the tables or graphs in this book. To download the matching Excel ${ }^{\circledR}$ spreadsheet, just type the link into your Internet browser, starting with the http://dx.doi.org prefix.

If you're reading the PDF e-book edition, and your PC is connected to the Internet, simply click on the link. You'll find StatLinks appearing in more OECD books. 


\section{Reader's Guide}

$\mathrm{T}$ his publication presents indicators of entrepreneurship collected by the OECD-Eurostat Entrepreneurship Indicators Programme (EIP). Started in 2006, the programme develops multiple measures of entrepreneurship and its determinants according to a simplified conceptual framework that distinguishes between the manifestation of entrepreneurship, the factors that influence it, and the impacts of entrepreneurship on the economy or society. A set of indicators of entrepreneurial performance is proposed for understanding and comparing the amount and type of entrepreneurship that take place in different countries. This approach reflects the idea that analysts should not focus only on enterprise creation or any other single measure to study entrepreneurship: entrepreneurs and entrepreneurial forces can be found in many existing businesses and understanding the dynamism these actors exert on the economy is as important as understanding the dynamics of start-ups.

The indicators of entrepreneurial performance are presented for the following countries: Austria, Belgium, Brazil, Bulgaria, Canada, the Czech Republic, Denmark, Estonia, Finland, Hungary, Israel, Italy, Latvia, Lithuania, Luxembourg, the Netherlands, New Zealand, Norway, Portugal, Romania, the Slovak Republic, Slovenia, Spain, Sweden and the United States.

A selection of indicators of determinants of entrepreneurship is also included in the publication: the choice of the indicators was based on their novelty, i.e. they were originally compiled and harmonized by the OECD or were recently produced and or/updated by other international sources. The reader will find in an Annex a comprehensive list of indicators of determinants, which draws from the report Quality Assessment of Entrepreneurship Indicators prepared annually by the International Consortium for Entrepreneurship (ICE).

Each indicator is preceded by a short text that explains what is measured and that provides the policy context, followed by a detailed description of the definition and by clarifications concerning the cross-country comparability of the indicator.

\section{Data collection}

The set of indicators that are part of the EIP framework have not all reached the same degree of development. Some of them are well established components of regular data collections, while some others are only developed in a restricted number of countries and their harmonised definition forms the object of discussion. The indicators presented in this publication reflect this diversity:

1. Enterprises by size class

2. Employment by size class

3. Value added by size class

4. Exports by size class

5. Birth rate of employer enterprises

6. Death rate of employer enterprises 
7. Churn rate of employer enterprises

8. Survival rate of employer enterprises

9. Employment creation and destruction by employer enterprise births and deaths

10. Employment creation and destruction in surviving enterprises

11. High-growth enterprises rate

12. Gazelles rate

13. Distribution of enterprises by growth rate

14. Number of new enterprises

15. Distribution of new enterprises by industrial activity

16. Number of bankruptcies

17. Entrepreneurial activity by gender

18. Obstacles to entrepreneurship by gender

19. Share of foreign enterprise owners

20. Regulatory framework: Starting a business

21. Access to finance: Venture capital

22. Culture: The image of entrepreneurs

Indicators 1 to 13 are based on harmonised definitions. Their source is the OECD Structural and Demographic Business Statistics (SDBS) Database, with the exception of Indicator 4 which originates from the OECD Trade by Enterprise Characteristics (TEC) Database, and Indicator 13 which is based on a FORA-NESTA research report. SDBS data are collected annually via harmonised questionnaires. Data on Indicators 1 to 3 refer to Structural Business Statistics, while Indicators 5 to 13, i.e. the core indicators of entrepreneurial performance, consist of Business Demography data.

Indicators 14 to 16 are the result of a new data collection process. They are designed to complement the harmonised business demography indicators from SDBS as their main purpose is to provide timely information, although this involves limitations in terms of cross-country comparability.

Data on women entrepreneurship (Indicators 17 and 18) and migrant entrepreneurs (Indicator 19) are presented for illustrative purposes; data collection in these two domains is underdeveloped and the EIP has started work to fill the gap. Data presented are drawn principally from national statistics offices, although in one case a non official source is used.

The remaining indicators represent a selection of determinants of entrepreneurship, chosen either for their novelty or because they are the results of an original collection/ harmonisation process by the OECD. The sources of data are diverse and include both official and non official sources.

\section{Size-class breakdown}

Structural Business Statistics indicators usually focus on 5 size classes based on the number of persons employed, where the data across countries and variables can be most closely aligned: 1-9, 10-19, 20-49, 50-249, 250+. Not all country information fits perfectly ino this system however and divergence from these target size classes are reported in each session. 
For Business Demography data, because a vast majority of newly created enterprises are micro enterprises, the analysis is usually even more focused on these very small enterprises and the typical collection breakdown is 1-4, 5-9, 10+.

\section{Activity breakdown}

For business demography indicators, a breakdown by activity is also proposed in Part II. Data are usually broken down into manufacturing and services industries.

Manufacturing comprises: Mining and quarrying; Manufacturing; Electricity, gas and water.

Services comprise: Wholesale and retail trade; Hotels and restaurants; Transport, storage and communications; Financial intermediation; Real estate, renting and business activities.

For the employer enterprise birth and death rates, data are also presented for the following industries: Food products, beverages and tobacco; Electrical and optical equipment; Trade; Other business services.

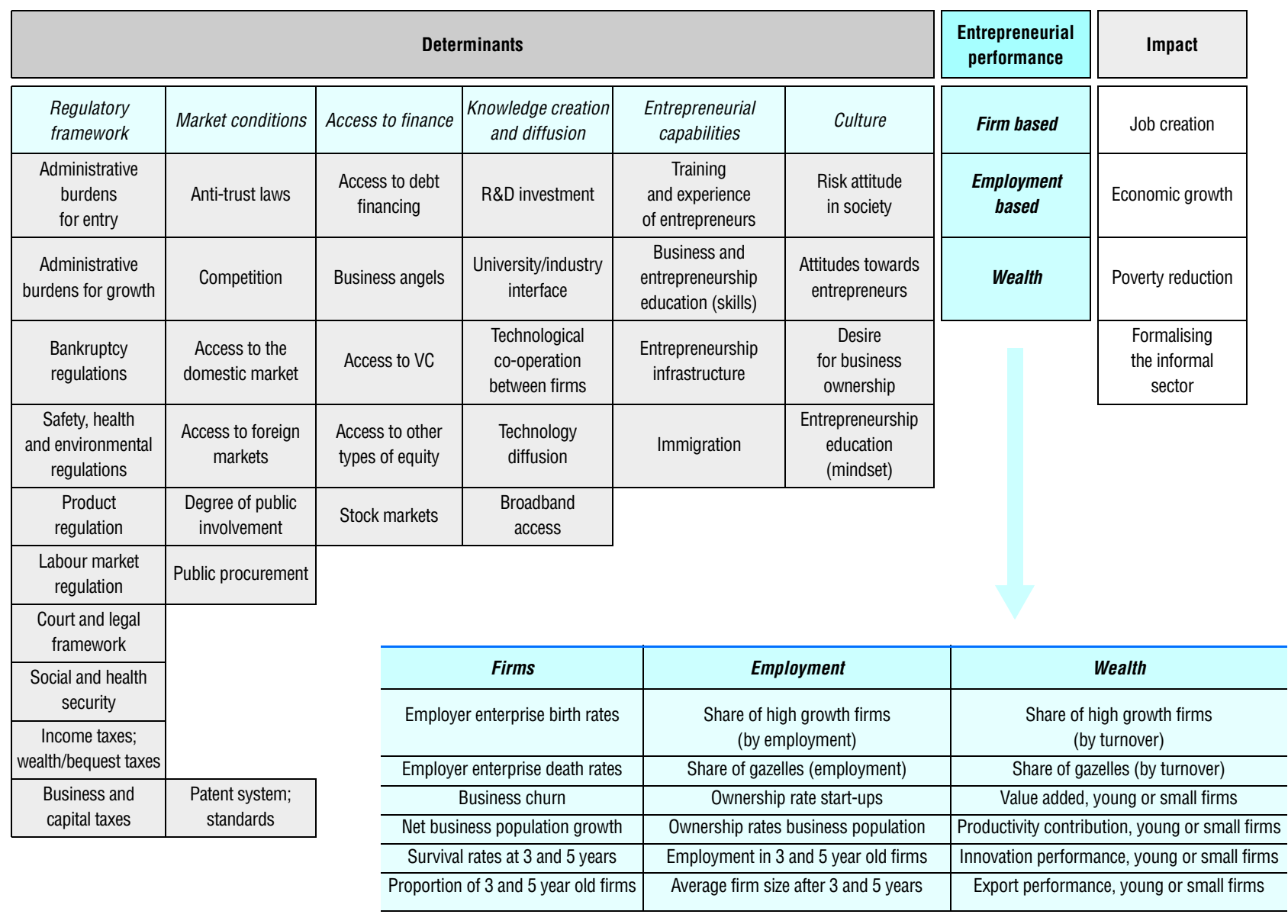



PART I

\section{Measuring Entrepreneurship}



PART I

Chapter 1

\section{Entrepreneurship Indicators and Business Registers:} The Importance of International Comparability 


\subsection{Background}

The recognition that entrepreneurship and entrepreneurs are important drivers of economic growth, employment, innovation and productivity has been long understood by analysts and economic theoreticians, indeed, centuries if one goes back to Cantillon, the first academic to explicitly attempt to define, and describe the role of, entrepreneurs.

In recent decades, this recognition has accelerated, with policy makers in many countries and international organisations explicitly recognising the importance of entrepreneurship and making general statements about their commitment to improving the entrepreneurial environment, whether by removing obstacles or via more direct targeted actions.

The pursuit and development of these policies have until recently been hampered by the limited, albeit growing, empirical information relating to the factors that affect entrepreneurship and the benefits of it. Policy references to entrepreneurship were typically equated with small and medium sized enterprises (SMEs) in general or even numbers of selfemployed. Neither of which fully captures the totality and complexity of entrepreneurship.

This, in part, reflects the greater availability of statistics on SMEs and the self-employed but it also reflects the general ambiguity relating to entrepreneurship. What compounded this ambiguity was the need for policy makers to be able to make international comparisons of entrepreneurship. In the absence of definitions that captured the essence of entrepreneurship, and of entrepreneurship indicators that were internationally comparable, policy makers were left somewhat rudderless when it came to developing policies, particularly when these related to learning from international best-practice.

These shortcomings and the growing importance of policies towards entrepreneurship magnified the need for a sounder basis for internationally comparable indicators of entrepreneurship and for an internationally accepted measure of entrepreneurship. The aim was to be able to provide information not only on how many entrepreneurs there were or the level of entrepreneurship, but also on determinants, and, ideally, on impacts. Indeed, creating a more entrepreneurial economy is merely a means to some bigger end, and not an end in and of itself.

Given its experience in international data development, many countries and groups turned to the OECD for assistance and guidance in developing such a framework by capitalising on its international networks of statisticians, analysts and policy makers. This led the OECD to create an OECD-Eurostat Entrepreneurship Indicators Programme (EIP) ${ }^{1}$ that has been at the vanguard of investigations and developments that seek to improve the current understanding and measurement of entrepreneurship.

\section{Defining entrepreneurship}

Entrepreneurship is a phenomenon that manifests itself throughout the economy and in many different forms with many different outcomes, and these outcomes are not always related to the creation of financial wealth; for example, they may be related to increasing employment, tackling inequalities, or indeed, increasingly, environmental issues. The 
challenge for the EIP therefore was to better understand these diverse outcomes and manifestations whilst at the same time remaining focused on the measurement of entrepreneurship. Key to this was a definition that captured the essence of entrepreneurship, one that was able to encompass these diverse issues, while at the same time remaining focused and most importantly measureable.

The EIP definition is described below. Its focus is deliberately to target business related entrepreneurship. The definition considers three components: Entrepreneurs, Entrepreneurial Activity and Entrepreneurship.

- Entrepreneurs are those persons (business owners) who seek to generate value, through the creation or expansion of economic activity, by identifying and exploiting new products, processes or markets.

- Entrepreneurial activity is the enterprising human action in pursuit of the generation of value, through the creation or expansion of economic activity, by identifying and exploiting new products, processes or markets.

- Entrepreneurship is the phenomenon associated with entrepreneurial activity.

In the context of the definitions above it is instructive to mention a few points:

- The first relates to an important distinction between Entrepreneurs and Entrepreneurial Activity. Where there are entrepreneurs there will always be entrepreneurial activity but it is important to note that the latter is not dependent on the existence of the former. This is important because the definition recognises that individuals within businesses may demonstrate entrepreneurship without necessarily having a stake in the company. This means that all companies, even those without an entrepreneur at their helm, can be entrepreneurial. Companies owned by shareholders or trust funds for example and managed/run by salaried directors can still be entrepreneurial and the way they operate their businesses in identifying and exploiting new products, processes or markets can be of benefit to other businesses owned and managed by entrepreneurs.

- The second point, which follows from the first, is that entrepreneurs and entrepreneurship are not concepts that relate exclusively to small businesses or the self-employed, as many studies, through expedience, have often assumed. The EIP view is that the creation of value through the identification and exploitation of new products, processes and markets is not uniquely the preserve of small companies or entrepreneurs, important though these are to the entrepreneurial process. Moreover it is important to avoid a definition that is possibly counter-productive from a policy perspective. Clearly, large companies can be entrepreneurial and these companies should not ignored when formulating entrepreneurship policies.

- The third point ties entrepreneurship very closely to the idea that there is something different about entrepreneurial businesses that sets them apart from other businesses; namely they are in the business of doing something new, whether that be by creating/ identifying new processes, products or markets. Not all businesses are entrepreneurial, indeed not even all new businesses are necessarily entrepreneurial (which has important consequences for the framework and supporting indicators developed by the EIP and how they should be interpreted).

- The fourth hinges very much on the "seeking". Many studies of entrepreneurship investigate and focus only on those entrepreneurs or entrepreneurial businesses that succeed. Failure is a very important part of the entrepreneurial process and much can be learned from understanding it. Entrepreneurs who failed were still entrepreneurial and, indeed, entrepreneurs. 
- The final point concerns "value". Policy makers are interested in facilitating or encouraging the growth of entrepreneurship because it is recognised as a force for good. How this "good" is achieved, indeed, determining what is "good" is the role of the policy maker. These "goods" or objectives are about creating value in one domain or another, and, as noted above, these can be very diverse. Therefore "value" covers both monetary and nonmonetary returns. These values are, naturally, identified as objectives or targets by policy makers, who will then develop policies designed to achieve them. Some countries for example will focus on entrepreneurship's contribution to economic growth. Other countries might instead focus on entrepreneurship's contribution to solving environmental problems or its contribution to social inclusion.

\section{Developing indicators}

Given the diversity of outcomes and manifestations, it is obvious that no single indicator can ever adequately cover entrepreneurship, especially given the different objectives. Some entrepreneurs, for example, will have limited growth potential, reflecting the value embodied in their idea, or their own attributes/experiences and motivation. Others will have enormous growth potential that can be measured both ex ante and ex post To encompass these differences, the indicators need to be used as vehicles that point policy makers in the right direction relevant to the entrepreneurship related objective they wish to achieve.

The entrepreneurial indicators developed by the EIP, and described in detail in this publication, comprise a basket of indicators that are generally thought to reflect entrepreneurship and that fit within the definitions outlined above. Thus, the list identifies a number of indicators that target, to varying degrees, different aspects of entrepreneurship and different types of entrepreneurs. In this sense, it is important to recognise too that the indicators are in some respect merely proxies for entrepreneurship or entrepreneurs. For example, not all high-growth firms embody entrepreneurship. But the inclusion of these indicators reflects the pragmatic approach necessary in the construction of a set of indicators, that need to be measurable in a harmonised, achievable and comparable way across countries.

In considering the pragmatic nature of the indicators, the EIP also recognised the practical constraints of restricting the burdens placed on businesses. This consideration guided the EIP away from the development of a new survey conducted by national statistics institutes (NSIs). Instead, the focus was on the development of indicators that could be readily obtained from information already collected by NSIs. One such source of information that readily lent itself to this objective was statistical business registers.

\subsection{The importance of statistical business registers in achieving comparability}

The statistical business registers are fundamental to the collection of information on, and the construction of surveys of, businesses. They contain most of the basic information essential to the development of business demography statistics; especially internationally comparable indicators as there is, at least in principle, good comparability of registers. ${ }^{2}$

The registers are themselves usually created from a combination of sources from different national administrative and statistical institutions, and typically contain the following information:

- The name of the business.

- A business identifier.

- The address. 
- The country of ownership.

- The description of the business activities (and possible changes in its main activity).

- The legal form (public corporation, sole proprietor, partnership, etc.).

- Information related to employment.

- Financial indicators such as turnover or revenue.

- The description of the links to other businesses within the same country or abroad.

Differences in registers arise, in general, in the context of the completeness of coverage of businesses. In theory, all businesses should be covered in a statistical business register, irrespective of the business size or its legal nature. In practice, however, there will be cross country differences reflecting national circumstances and data availability. For example, most countries will exclude many micro enterprises - i.e. those that provide some form of subsistence or supplementary income to the owner, usually the sole-proprietor the self employed; and often also enterprises without employees. Differences in these thresholds can considerably impair the international comparability of indicators of businesses, whether they be pure simple descriptive statistics, such as the number of businesses or indeed the number of births.

To accommodate for these differences the EIP developed the concept of an employerenterprise unit as the relevant statistical unit; meaning that administrative differences that lead to different coverage of businesses in statistical business registers could be overcome. This was not the sole driver for the focus placed on an employer-enterprise unit. The focus also reflects, in some respects, the application of an economic relevance threshold. Figure 1.1 shows, in a simple way, the importance of the threshold of an employer-enterprise in developing comparable estimates of entrepreneurship across countries. It compares birth rates across European countries, from the Employer Business Demography (EBD) data collection, using the employer-enterprise as the statistical unit with the rates derived using the simple enterprise as the statistical unit (Regulation (EC) No. 295/2008 of the European Parliament and of Council of 11 March 2008 concerning structural business statistics (recast), Annex IX). The key point to note here is the significant differences that arise between countries using the different rates. Because the population of businesses captured by the employer-enterprise threshold is more comparable across countries than the simple enterprise notion, comparisons of entrepreneurial statistics are also more meaningful.

That is not to say that firms without employees or micro firms are not relevant for entrepreneurship studies. In fact, the development of the employer-enterprise as the statistical unit does not exclude these firms from analysis. It is not the sheer number of micro firms or self-employed that is of interest, per se, for those studying entrepreneurship, it is the potential for those firms to be drivers of job creation, growth and innovation. In this respect, it is instructive to consider the time-line that sees the business evolve from an idea to a large employer. One could, albeit impractically, decide that the basis for measurement was when the idea, or "seed" was germinated; or when the business was first registered; or when it sold its first product or, as the EIP has concluded, when the first employee is taken on. Any of these points in time could be defined as the basis for "births". If one considers the period prior to the birth as the gestation period, it is clear that the very small microfirms that are of interest to entrepreneurship policy makers, will nearly always evolve into employer enterprise firms, and, so be captured by the EIP definition. 
Figure 1.1. Employer enterprise birth rates and enterprise birth rates

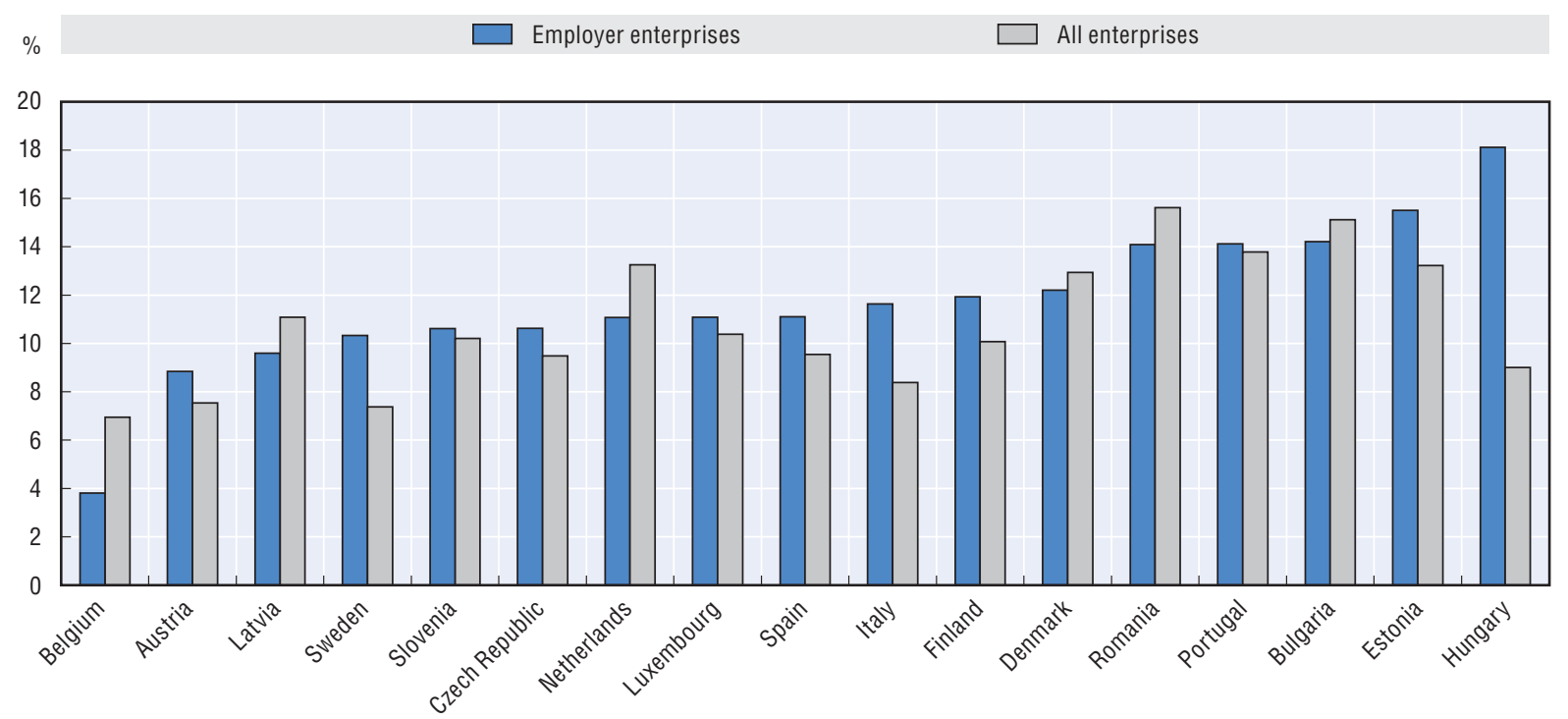

Source: Eurostat (2010a).

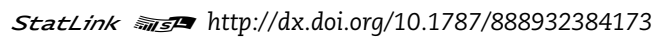

\section{Comparability and timeliness}

There is however one noticeable drawback with the use of statistical business registers. Whilst they provide the basis for good comparability they cannot, unfortunately, be used to provide very timely indicators of the entrepreneurial environment. This reflects the fact that a number of adjustments are needed in statistical business registers to correct for distortions produced by certain demographic events, in order to arrive at comparable and meaningful concepts.

The need for timely indicators is as important as the need for comparable indicators. As such, the EIP has developed additional indicators, based on administrative, typically legal, sources that can be used to provide an indication of changing patterns in births and deaths of businesses, as a timely supplement to the comparable benchmark estimates provided by statistical business registers. However, it is crucial to note that the comparability of the indicators, based on these administrative registers, across countries is far from perfect, certainly when compared to the benchmark series based on statistical business registers, adjusted for certain demographic events.

The lack of comparability in entrepreneurship statistics based on administrative registers, which are produced by many other institutions, and where very often the definition of a business varies across countries, is arguably not fully understood by users of entrepreneurship statistics. It is instructive therefore to clarify how differences in coverage and concept in administrative registers impact on comparability, and, in doing so explain why the benchmark series (produced using statistical business registers) presented in this publication are less timely than the information provided by administrative registers. This section does this by shaping the discussion around the two most important, and certainly most commonly cited statistics used in entrepreneurship studies: births and deaths of enterprises. 
Enterprises can appear and disappear from administrative and statistical business registers in a number of ways reflecting many demographic events, such as mergers and take-overs. Many of these entries and exits are not therefore directly relevant to the study of entrepreneurship or creative destruction. For example the economic impact of mergers will differ, and certainly their impact on employment; often mergers lead to reductions in overall employment, whereas completely new creations will generate employment, even if they result in employment losses in other businesses through competitive pressures related to creative destruction.

Moreover, pure appearances on, and disappearances from, registers are not and never likely to be comparable across countries. For example, in practice, entries are derived from registrations with administrative sources but the legal and administrative requirements that determine how and when a business should register with national administrative sources vary considerably from country to country, and are likely to continue to do so.

The EIP measure of "births" attempts to differentiate between entries and creations, which include any demographic event that leads to the creation of a new enterprise even if the enterprise previously existed in a different form. Similarly the concept of "deaths" attempts to differentiate exits from demographic events that lead to the disappearance of an enterprise from a register but that reappears in fundamentally the same form.

The following sets out the series of demographic events that can appear on administrative and indeed statistical business registers that need to be adjusted for in order to produce internationally comparable statistics. The central most important point to note, vis-à-vis the comparability of EIP statistics with that produced using counts from administrative registers, is that the definition of the business (an employer-enterprise) is comparable in the EIP but cannot be assumed to be so for administrative registers:

- Changes in Controlling Legal Unit, Activity and Locations.

- Mergers.

- Renamings.

- Break-ups.

- Split-offs.

- Changes of Ownership (one-to-one take-over).

- Joint Ventures.

- Re-structuring: within an Enterprise Group and Enterprise Groups.

- Relocation.

- Reclassification.

- Reactivation.

Correcting for these events in constructing comparable business demography statistics is central to the value-added provided by the EIP statistics. The nature of the adjustments can mean that timeliness is necessarily affected. For example, to determine whether a business has died, or is merely dormant, two periods (years) need to have passed without the same business reappearing (in one shape or form) on the register. In other words deaths and death rates can only be determined, generally, about three years after the date the business actually failed. How important these adjustments are can be illustrated by Figure 1.2, which compares real births and entries for France. 
Figure 1.2. Births and entries in France

Thousands

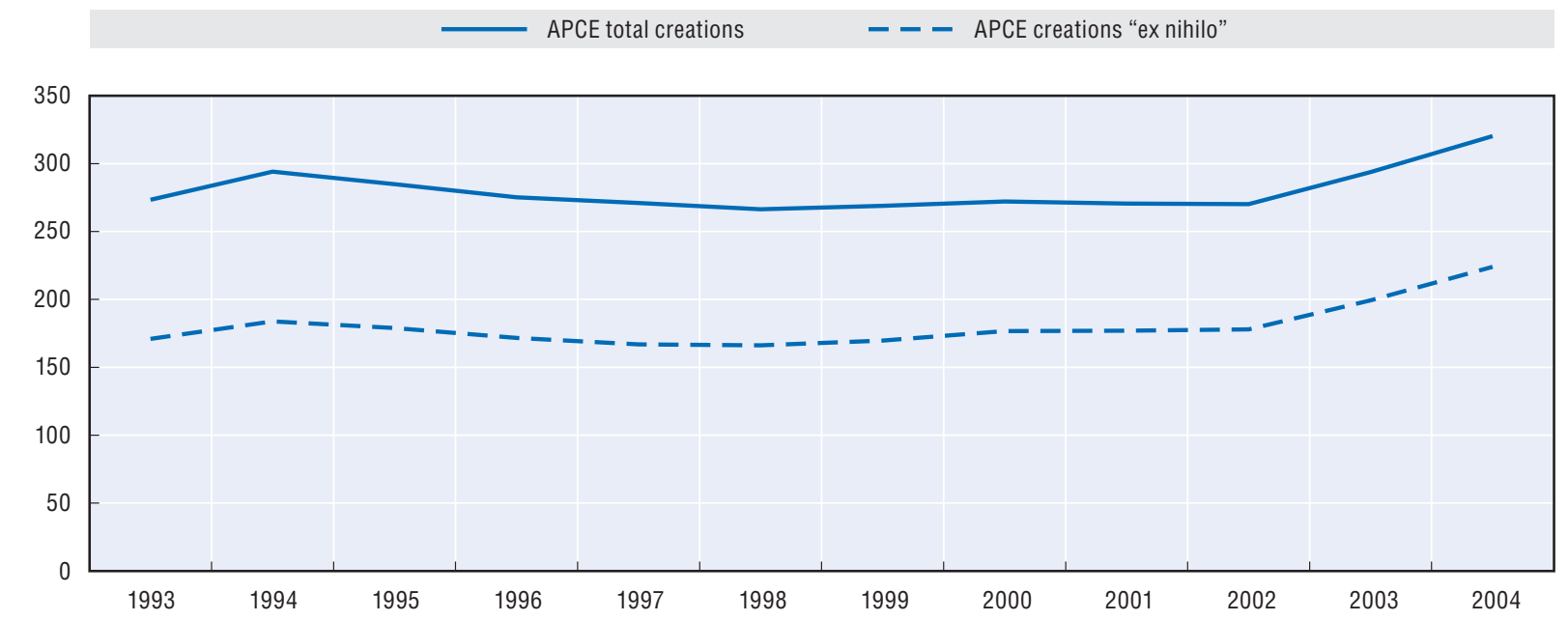

Source: Agence pour la Création d'Entreprises (APCE), Observatoire de la Création.

StatLink क्गाड http://dx.doi.org/10.1787/888932384192

\subsection{Developing timely indicators of entrepreneurship}

Notwithstanding the importance of comparable estimates of entrepreneurship across countries, the EIP recognizes the importance of timely estimates and to this extent has supplemented its statistical business register-based data with a new set of timely indicators of entrepreneurship (TIE). Unlike the benchmark business demography indicators, which, although comparable across countries, are typically only available two to three years after the reference period during which they occur, the TIE data on enterprise creations and enterprise failures are typically available only a few months after the reference period. As discussed below, the price for more timely data is less international comparability. This reflects the fact that the registers are typically administrative, reflecting some form of legal requirement for registration or de-listing, which differ, often considerably, across countries. Sometimes this will depend on differences in the sectors covered, sometimes on differences in the legal status (incorporated, unincorporated), sometimes on size, and sometimes on other administrative requirements such as labour laws, or VAT registration.

This difference in comparability across countries is one of the reasons a distinction is made between what is referred to as "births" and "deaths" in the EIP benchmark statistics and "creations" and "failures" in the TIE. Another important reason however reflects the underlying difference in concept of the related measures.

A creation, for example, may occur through a merger, takeover, or change of name, activity or ownership. None of these qualify as a birth in the benchmark birth measure. Similarly for firm closures, the main source of information is bankruptcy records. But not all declarations of bankruptcy necessarily result in the death of a firm. The business for example may be restructured or bought-out during this period, depending on the bankruptcy laws in place; and neither of these events would be considered a death in the benchmark statistics.

Because of the differences across countries, the emphasis is placed on cross-country comparisons of trends (seasonally adjusted using the X12 ARIMA model) and growth rates, rather than exact levels. Interestingly, trends in countries' adjusted series on firm creation 
and bankruptcies show a remarkably similar pattern across countries. The precise sources and definitions of enterprise creations and bankruptcies are presented in Annex II.A.

The ability of TIE to facilitate the analysis of the impact of the recent economic and financial crisis on enterprise creations and bankruptcies is highlighted by the data shown in Figure 1.3 which covers the period 2007-2009. The availability of updated data identifies changes in entrepreneurial performance during the crisis. In particular, the TIE data indicate that in 2008 , the number of enterprises diminished in all countries for which data were available, except France, although the size of decrease varied considerably across countries. The decline continued in 2009 in most countries, though a few showed small increases.

Figure 1.3. Number of new enterprises, percentage changes from previous year

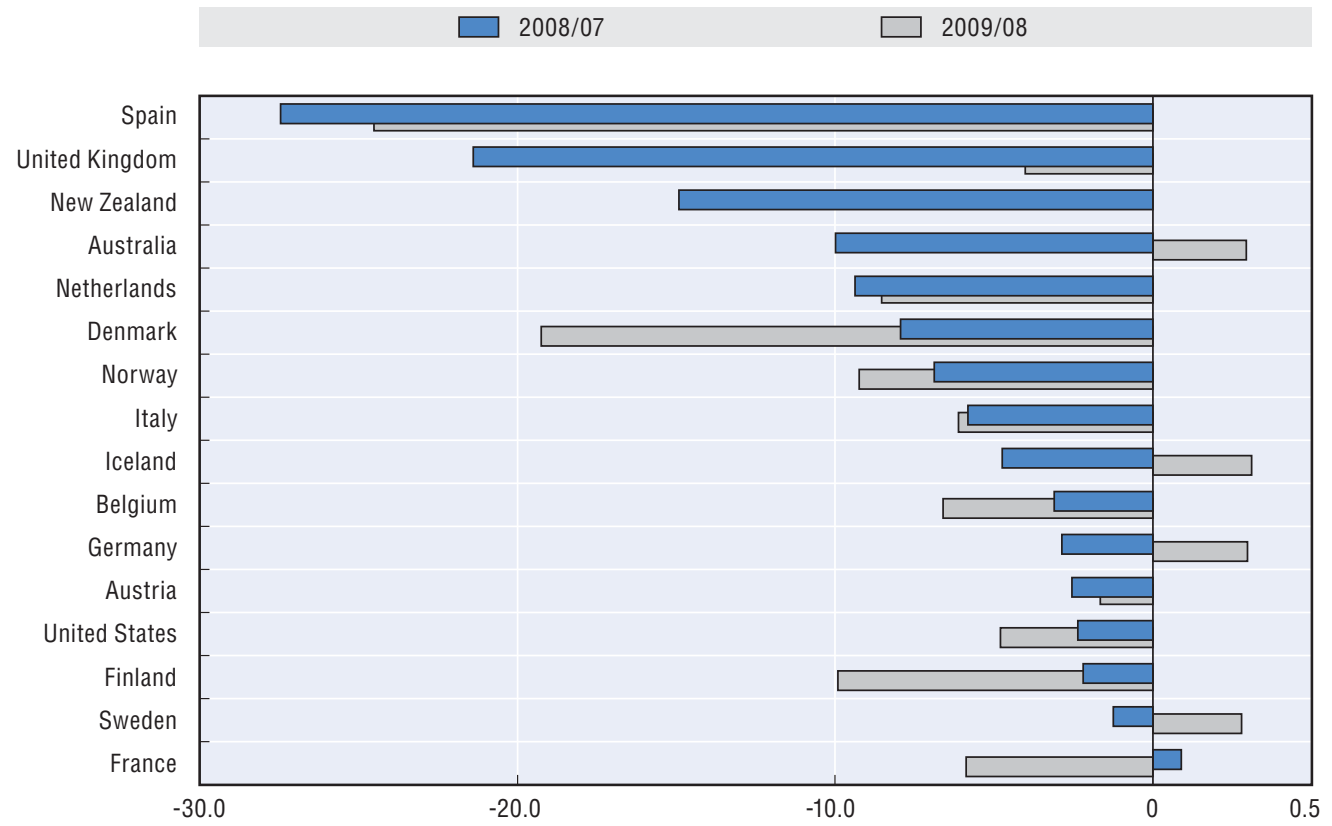

Source: OECD, Timely Indicators of Entrepreneurship Database.

The EIP intends to expand the Database of Timely Indicators of Entrepreneurship to cover additional countries, and to ameliorate, to the extent possible, the cross-country comparability. Work is under way to assess the correlation of the timely indicators with the harmonised benchmark business demography indicators. Finally, Eurostat has investigated the use of the alternative sources of data on firm entries and exits to estimate official business demography data; this is a promising area of research that the EIP is interested in considering. 


\section{Notes}

1. For more information on the EIP including feasibility studies and meetings that have been instrumental in the development of the framework, see www.oecd.org/statistics/ entrepreneurshipindicators. The introductory section of this chapter draws on two milestone documents produced by the EIP: Ahmad and Seymour (2008) and Ahmad and Hoffman (2008).

2. For a thorough discussion on business registers comparability, see OECD (2006) and Vale (2005).

\section{References}

Ahmad, N. and A. Hoffman (2008), "A framework for addressing and measuring entrepreneurship", OECD Statistics Working Paper, No. 2008/02, http://dx.doi.org/10.1787/243160627270.

Ahmad, N. and R. Seymour (2008), "Defining Entrepreneurial Activity", OECD Statistics Working Paper, No. 2008/01, http://dx.doi.org/10.1787/243164686763.

European Commission (2003), Business Register Recommendations Manual, 2003 http://ec.europa.eu/ eurostat/ramon/statmanuals/files/KS-BG-03-001-_-N-EN.pdf.

Eurostat (2010a), Development of Business Demography Statistics, DOC.8/EN/EUROSTAT/G2/SBS/NOV10.

Eurostat (2010b), Estimation of Recent Business Demography Data, DOC.06/EN/EUROSTAT/G2/BD/JUN10.

OECD (2010a), “Measuring Entrepreneurship”, OECD Statistics Brief, No. 15. www.oecd.org/dataoecd/50/ 56/46413155.pdf.

OECD (2010b), Structural and Demographic Business Statistics, Paris. www.oecd.org/document/17/ 0,3343,en_2649_34233_36938705_1_1_1_1,00.html.

OECD (2006), “A Proposed Framework for Business Demography Statistics", Nadim Ahmad, OECD Statistics Working Paper, 2006.

OECD-Eurostat (2007), Eurostat-OECD Manual on Business Demography Statistics, Paris, www.oecd.org/ document/34/0,3343,en_2649_34233_39913698_1_1_1_1,00.html.

The OECD Entrepreneurship website, www.oecd.org/std/entrepreneurship.

Vale, S. (2005), The Coverage of Micro-Enterprises in Business Registers, Paper presented at the Structural Business Statistics Expert Meeting: "Towards better Structural Business and SME Statistics", Paris, 3-4 November, www.oecd.org/dataoecd/32/46/35506105.pdf. 
PART I

Chapter 2

\section{Measuring Green Entrepreneurship}


$\mathrm{I}_{\mathrm{n}}$ entrepreneurship in boosting the economic activity has been emphasized in many countries. Governments have often allocated important shares of recovery packages to helping entrepreneurs, either in the form of loan guarantees, tax incentives, research credit designed to boost innovation, or systems to encourage self-employment. Yet, instead of being neutral in their industry targets, stimulus plans have often given priority to environmentally-friendly investment such as projects for improving energy efficiency, or enhancing sustainable transport. These priorities are not new. In almost all cases, they have been part of longer-term commitments towards environmental protection, support for smaller enterprises, and innovation. Within this difficult economic context, many countries have increased public expenditure to revive growth, while also taking the opportunity to orientate national economies towards long-term sustainability and "green growth". According to the United Nations Environmental Program (UNEP, 2009) South Korea invested in 2009 79\% of its total economic stimulus package in "green activities" representing almost 7\% of its GDP, followed by China and Australia with $34 \%$ and $21 \%$ of their stimulus packages going to "green investments", corresponding to $5.2 \%$ and $0.9 \%$ of their respective GDP. In this context, the study of green entrepreneurship went from being simply "fashionable" to being essential for policy guidance.

The OECD has been assisting efforts to foster green growth as well as to guide relevant policy initiatives on the basis of statistical evidence. As part of the OECD Green Growth Strategy, this chapter presents existing definitions for green entrepreneurship, past work in the direction of quantifying its dynamics, as well as key findings across a number of countries, using existing OECD data for a selection of green sectors.

\subsection{Definitions and measures of green entrepreneurship \\ Conceptual framework}

Defining green entrepreneurship is a difficult task. The concept itself is relatively recent and has been receiving growing attention since the 1990s. The interest in green entrepreneurship is not only reflected in the growing literature on the topic but also in the proliferation of terms used to identify the concept itself. Among the terms available to describe green entrepreneurship, the following are the most commonly used: ecoentrepreneurship, ecopreneurship, environmental entrepreneurship, sustainable entrepreneurship, ecological entrepreneurship, enviro-preneurship or sustainopreneurship. How can these concepts be operationalised? What activities could be included in the "green" part of entrepreneurship? What are the main characteristics of green entrepreneurs? The literature has not provided clear-cut answers to these questions.

A green entrepreneur can be either making her business "green" or simply entering a "green business". In other words, green entrepreneurship could be defined in terms of the technology used for production in any sector of the economy, or in terms of the sectors firms are active in, in which case our attention is restricted to parts of the economy producing specific types of output. The former is sometimes referred to as a process 
approach in defining green business, while the latter as an output approach. Authors tend to add complexity to those definitions by often incorporating ethical, social, or environmental motivations in definitions of green entrepreneurial activity. ${ }^{1}$ The following illustrate the broad range of possible interpretations of the concept:

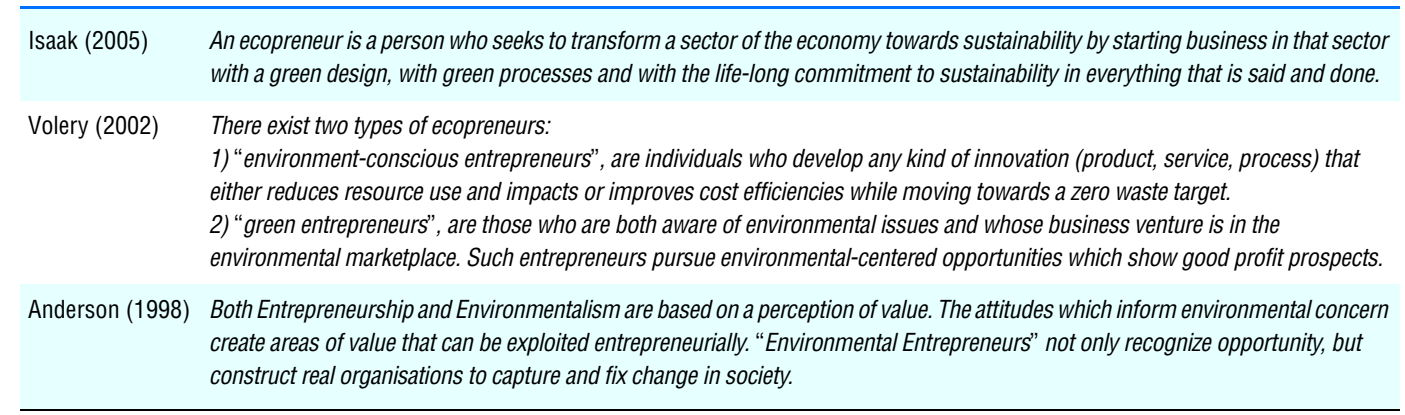

In this publication the definition of green entrepreneurship adopted is based on the type of output produced by firms. Put simply, the term "green entrepreneurship" will be interpreted as "entrepreneurship" in "green" sectors, where "green" refers to specific types of outputs, but it is fully recognized that this definition tells only part of the story on green entrepreneurship. The second task involves a clear delimitation of "green" (or "environmental") sectors, which would also be essential for studying any other green topic such us "green technology" or "green jobs".

The definition of "green" adopted in this publication is in line with previously expressed views on the meaning and dimensions of the term. In the context of the OECD Green Growth Strategy (OECD, 2010) for instance, a basic measurement framework is put forward which reflects the common double-faceted approach on "green". More specifically, a first set of indicators is proposed to inform about environmental efficiency in production, and a second set informing about economic activity in conjunction with environmental goods and services.

The OECD/Eurostat (1999) proposed a definition of the environmental industry following an output approach on the basis of specific criteria:

"The environmental goods and services industry consists of activities which produce goods and services to measure, prevent, limit, minimize or correct environmental damage to water, air and soil, as well as problems related to waste, noise and eco-systems. This includes cleaner technologies, products and services that reduce environmental risk and minimize pollution and resource use."

In its one-time Survey of Environmental Products and Services (SEPS), the United States Census Bureau (Becker and Shadbegian, 2008) had already defined the environmental sector in the United States, in a very similar way to the OECD/Eurostat:

"The manufacture of products, performance of services and the construction of projects used, or that potentially could be used, for measuring, preventing, limiting, or correcting environmental damage to air, water, and soil, as well as services related to the removal, transportation, storage, or abatement of waste, noise, and other contaminants."

The OECD proposed as early as in 1996 (see OECD, 1996) a framework for delimiting the environmental sector which includes a set of "core industries", that is, categories of activities which are entirely environmental (such as Recycling - ISIC 37, or Wholesale of waste and scrap - ISIC 51.49), and a "non-core" set containing both activities with and without environmental relevance (such as Construction - ISIC 45, where firms specialized 
in the construction of energy-efficient buildings are considered environmental, while firms engaged in the construction of roads are not). According to the OECD framework "non-core does not mean not important, but rather areas where identification, measurement and agreement problems still exist" (OECD, 1996). The share of "green" in "non-core" industries is typically identified by examination of the main activity of each firm in the industry (Brolinson et al., 2005). The distinction between a "primary" and "secondary" set of environmental activities is central in this framework. A firm belonging to one of the "core" sectors declares necessarily a primary activity which is environmentally relevant, while firms in "non-core" sectors could potentially declare such activities as primary, secondary, or not declare them at all. Most studies that measure the environmental sector report statistics broken down by "core" and "non-core" industries, as well as "primary" (otherwise "specialised") and "secondary" activities.

\section{Empirical framework: Measurement of green activities}

Eurostat invited all European countries to propose a clear delimitation of green sectors on the basis of the criteria included in the manual published jointly with the OECD. Examples illustrating alternative ways of delimiting the environmental industry were also included in the manual (see Annex I.A for a specific example). A number of studies appeared in the literature as a result of this call. The Hungarian Central Statistical Office (HCSO, 2005), Statistics Sweden (Brolinson et al., 2005), the Department for Environment Food and Rural Affairs in the UK (Mansfield and Thomas, 2005), Statistics Netherlands (Van Rossum and Schenau, 2006), as well as the Belgian Planning Bureau (Janssen and Vadille, 2009), all made attempts to measure the size and dynamics of the environmental industry following recommendations by the OECD/Eurostat. Authors report on the number of firms active in the industry, the number of employees, turnover, and occasionally exports and value added.

The delimitation of the environmental sector has also been discussed extensively within the United Nations (UN DESA, 2010), in an effort to establish a harmonized framework for the collection of environmental accounts. A number of recommendations regarding the classification of activities have recently been put forward for consultation, including the consideration of the environmental relevance of the intention of producers in cases where the technical nature of their activities is inconclusive.

It is noteworthy that much of the literature on green entrepreneurship lacks substantial empirical analysis. The theoretical debate that has emerged during the last few years due to the growing interest in the topic has undoubtedly contributed to a better understanding of the phenomenon. In the absence of stylized facts on the activity however, the debate often appears distant from the current conjuncture, and hence unable to offer tangible guidance to relevant policy initiatives (Box 2.1). Much more empirical work has been completed towards delimiting and measuring the environmental industry. While measuring green entrepreneurship accurately is still complex, figures on the evolution of the size of the green industry in each country can be used to illustrate rough entrepreneurial trends in these sectors.

In many of the studies measuring the environmental industry, entrepreneurial dynamics are presented indirectly through figures on the evolution of the number of firms between two or more points in time. For instance, Janssen and Vadille (2009) report that between 1995 and 2005 the Belgian environment industry has registered a growth of $44 \%$ in the number of firms, while firms involved in primary environmental activities have increased even more, by 53\%. Going a step further in their analysis, Brolinson et al. (2005) 
break down growth rates of primary and secondary activities by economic sector. More specifically, they show that in Sweden the largest increase in the number of firms declaring an environmental activity as primary between 2002 and 2005 occurs within Other Business Activities (ISIC 74) and in Mining and Manufacturing (ISIC 10-37), that is, within "non-core" sectors. The same holds, not surprisingly, for the largest increase in the secondary activities which occurs within Electricity, Gas and Hot Water Supply (ISIC 40) (Table 2.1).

Table 2.1. Number of establishments classified within the environmental industry by sector groups, Sweden, 2002-2005

\begin{tabular}{|c|c|c|c|c|c|c|c|c|}
\hline & \multicolumn{2}{|c|}{2002} & \multicolumn{2}{|c|}{2003} & \multicolumn{2}{|c|}{2004} & \multicolumn{2}{|c|}{2005} \\
\hline & Primary & Secondary & Primary & Secondary & Primary & Secondary & Primary & Secondary \\
\hline Mining and manufacturing (NACE 10-37) & 767 & 297 & 799 & 312 & 838 & 319 & 936 & 278 \\
\hline $\begin{array}{l}\text { Electricity, gas and hot water supply } \\
\text { (NACE 40) }\end{array}$ & 940 & 164 & 970 & 168 & 992 & 162 & 996 & 207 \\
\hline Wholesale and retail trade (NACE 50-52) & 1505 & 399 & 1515 & 413 & 1515 & 442 & 1616 & 486 \\
\hline Other business activities (NACE 74) & 748 & 686 & 793 & 709 & 805 & 729 & 1019 & 732 \\
\hline $\begin{array}{l}\text { Water distribution, sewage and waste } \\
\text { (NACE } 41+90 \text { ) }\end{array}$ & 1925 & & 1915 & & 1728 & & 1984 & \\
\hline $\begin{array}{l}\text { Other industries } \\
\text { (NACE 1-5, 45, 55-73, 75-85, 91-99) }\end{array}$ & 2953 & 1493 & 2998 & 1517 & 3162 & 1548 & 1958 & 1354 \\
\hline Total & 8838 & 3039 & 8990 & 3119 & 9040 & 3200 & 8509 & 3057 \\
\hline
\end{tabular}

Source: Brolinson et al. (2005)

Typically, studies on the green industry including some dynamic approach present figures on growth in employment along with number of firms, turnover, and other variables of interest. The sign and level of growth in employment is often in line with the one observed for the number of firms.

Numerous reports measuring the green industry have also been published on the basis of goods and services produced by firms. Statistics Canada (2004) established a very high disaggregation of green industrial activities at the NAICS 6-digit level (the North American Industry Classification System at the product level) in order to measure the environmental industry, and retrieved records of relevant transactions using firm surveys. The same approach has been followed by the United States Department of Commerce (2010), in a study where analysts applied a fairly general definition of "green" 2 to over 22000 product codes from the Economic Census in order to estimate the share of "green" in the US economy. In an effort to capture different views on the delimitation of the green industry, the study adopts a "narrow" definition including only products and services whose relevance is relatively undisputed (such as waste collection and disposal), as well as a "broad" definition with products and services whose "greenness" is much more subject to debate (such as waste transportation). The study presents results following both definitions.

The US Department of Commerce (2010) compares employment in environmental firms as a share of total manufacturing between 2002 and 2007 (Figure 2.1), following a narrow as well as a broad definition of "green". The study concludes that shares of green employment remain quite stable, despite the observed decrease in total numbers of employees. The green part of the economy seems to follow negative trends in manufacturing overall (US Dept. of Commerce, 2010). 
Figure 2.1. Green share of total manufacturing employment, 2002 and 2007

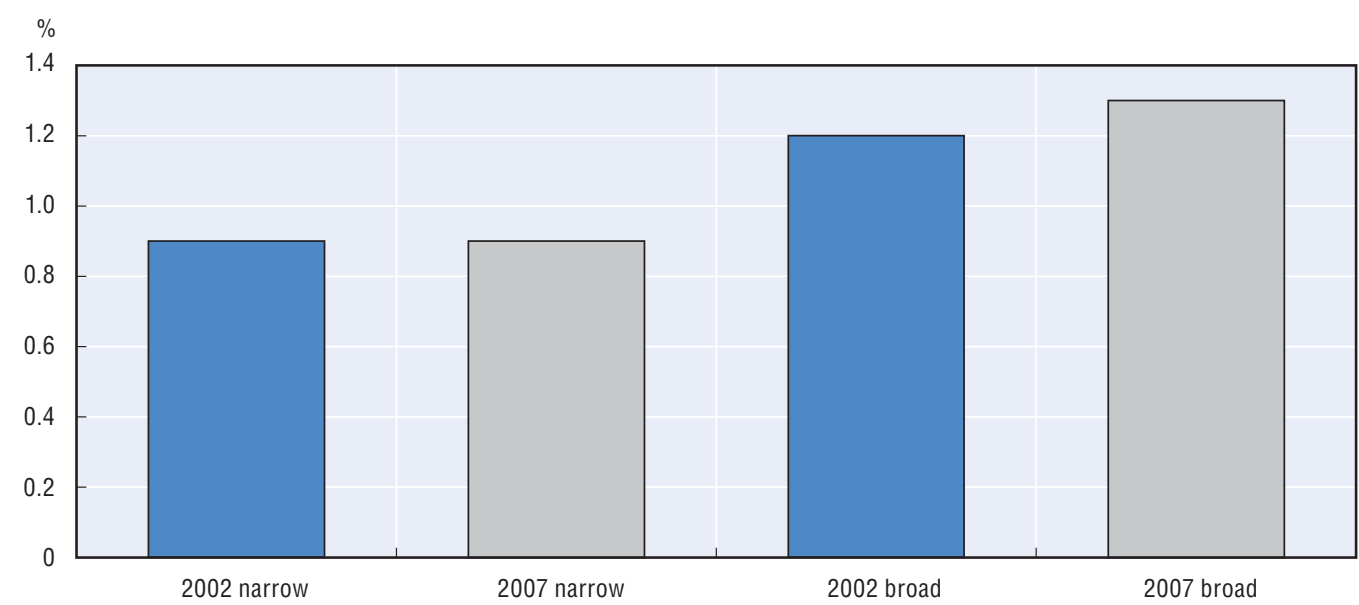

Source: United States Department of Commerce (2010).

\section{Box 2.1. Policies with an impact on green entrepreneurship}

Government policies rarely target explicitly the birth of new enterprises in environmental sectors. A sequence that is commonly observed in the green part of the economy is the adoption of policies for the protection of the environment, which in turn create favorable conditions for investment, growth, and the development of new firms in environmental sectors.

The example of the water sector in Israel is typical of the type of impact environmental policies can have on entrepreneurship (OECD, 2010, Annex II.B). To address the scarcity of water in the country, over the past two decades the Israeli government introduced policies to encourage reduced consumption and recycling of water, as well as strong pricing signals. These policies included abstraction and supply, water transportation and distribution, and wastewater policies. These factors had an impact on the demand for water and innovation incentives in the sector. As of 2007, 270 water-technology companies operated in Israel, employing almost 8000 people. About 60 companies among the 270 were start-up companies, established after 2001, and were involved in R\&D. In addition, exports of the water technology sector grew from USD 700 million in 2005 to some USD 850 million in 2006, a $21 \%$ increase.

Source: OECD (2010), Taxation, Innovation and the Environment, OECD, Paris.

\section{2. "Green" in the context of entrepreneurship}

The previous section discusses the statistical definition as well as a number of attempts to measure the size of "green sectors". Nonetheless, the fact that the environmental industries can be delimited in many different ways gives rise to the question of the suitability of various definitions for studying entrepreneurship. This section first outlines the reasons why entrepreneurial dynamics are not easily depicted for an aggregate of environmentally-relevant activities, and then proposes a way to proceed in order to best use the available data for measurement purposes.

\section{Measurement difficulties}

The most important challenge in measuring green entrepreneurship lies in separating unambiguously relevant activities within "green" sectors from activities occurring in the 
rest of the economy. Specifically, the indicators used to describe entrepreneurial performance (such as birth, death or survival rates of firms) are often not available at the detailed level of industrial activities characterised as "green". For instance, the OECD Structural and Demographic Business Statistics (SDBS) Database, which is used here as the main source for measuring entrepreneurial performance, only contains data within a two-digit industry classification. An analysis at that level makes it impossible to retrieve records of birth either of firms active in four-digit green industries, or of firms focusing on specific green products indentified under six-digit codes.

\section{Box 2.2. Detailed industry classifications across systems}

Detailed industry classifications are introduced in response to the latest needs in data collection. As needs for data collection are implemented independently across countries using different systems, classifications at the most detailed level of disaggregation exhibit inevitably differences among systems. For instance, NAICS (North American Industry Classification System) was revised in 2002, among other reasons, to identify additional industries for new and emerging activities. To that end, industries were created for internet services providers, web search portals, and internet publishing and broadcasting. Within NACE Rev. 1 (used by Eurostat) the telecommunications sector (64.2), was not disaggregated at the time. Although suggestions for the implementation of a more detailed system in telecommunications were not missing by 2002, there were significant time lags before some convergence occured. The differences remained strong only at a more detailed level of disaggregation.

The identification of green activities is typically done at a highly disaggregated level. The difficulty in finding some correspondence between industry classification systems at that level impedes the effort to collect comparable figures for the size of the environmental sector across different countries. Cross-country comparisons of entrepreneurship indicators using an (otherwise very similar) delimitation of "green sectors" becomes a nontrivial task.

\section{Trends in green entrepreneurship}

In order to best use the available data, a choice is made to focus on the few sectors that are entirely representative of activities in the green part of the economy. More specifically, this chapter presents results from a selection of two-digit "core" industries which are entirely environmentally-relevant: Recycling (ISIC 37); Collection, purification and distribution of water (ISIC 41); Sewage and refuse disposal, sanitation and similar activities (ISIC 90). The focus on these sectors is justified by the fact that they respond in their entirety to stimuli specific to green activities, and therefore to conditions that are favourable for entrepreneurial development in that industry. While the focus does not allow for general conclusions regarding the entire green economy, it allows the examination of two important issues: the degree of homogeneity in entrepreneurial trends within the green part of the economy, as well as the degree to which entrepreneurial dynamics in green sectors differ to the rest of the economy.

It is noteworthy that the focus on core sectors when analysing green activities is not new. A typical example of the same approach comes from a recently published competitiveness screening of the EU eco-industries (EU, 2009) based on statistical evidence from "core" industries and eco-construction. Its authors justify their focus by referring to 
"policy relevance, data availability, and homogeneity in terms of activities covered" by core environmental sectors.

In what follows, data on entrepreneurial performance in core sectors come from a number of different sources: the OECD Structural and Demographic Business Statistics (SDBS) Database, the OECD Database for Structural Analysis (STAN), and the Eurostat New Cronos Database. Depending on the source there is some variation in the sectoral coverage of each indicator.

Figure 2.2 illustrates the share of employment in the three core sectors of interest for a selection of European countries and the United States in 2002 and in 2007, as well as the average annual growth rate between these two points in time. The evolution of employment differs significantly among countries. Nordic countries (Finland, Sweden), Spain and Italy stand out, while some large economies such as the United States or Germany appear stable. In Central Europe, Hungary, Czech Republic, Slovenia the data reveal a quite high share of employment in purely green sectors.

Figure 2.2. Share of employment in ISIC sectors 37,41 and 90 in percentage of total economy ${ }^{*}$ 2002-2007

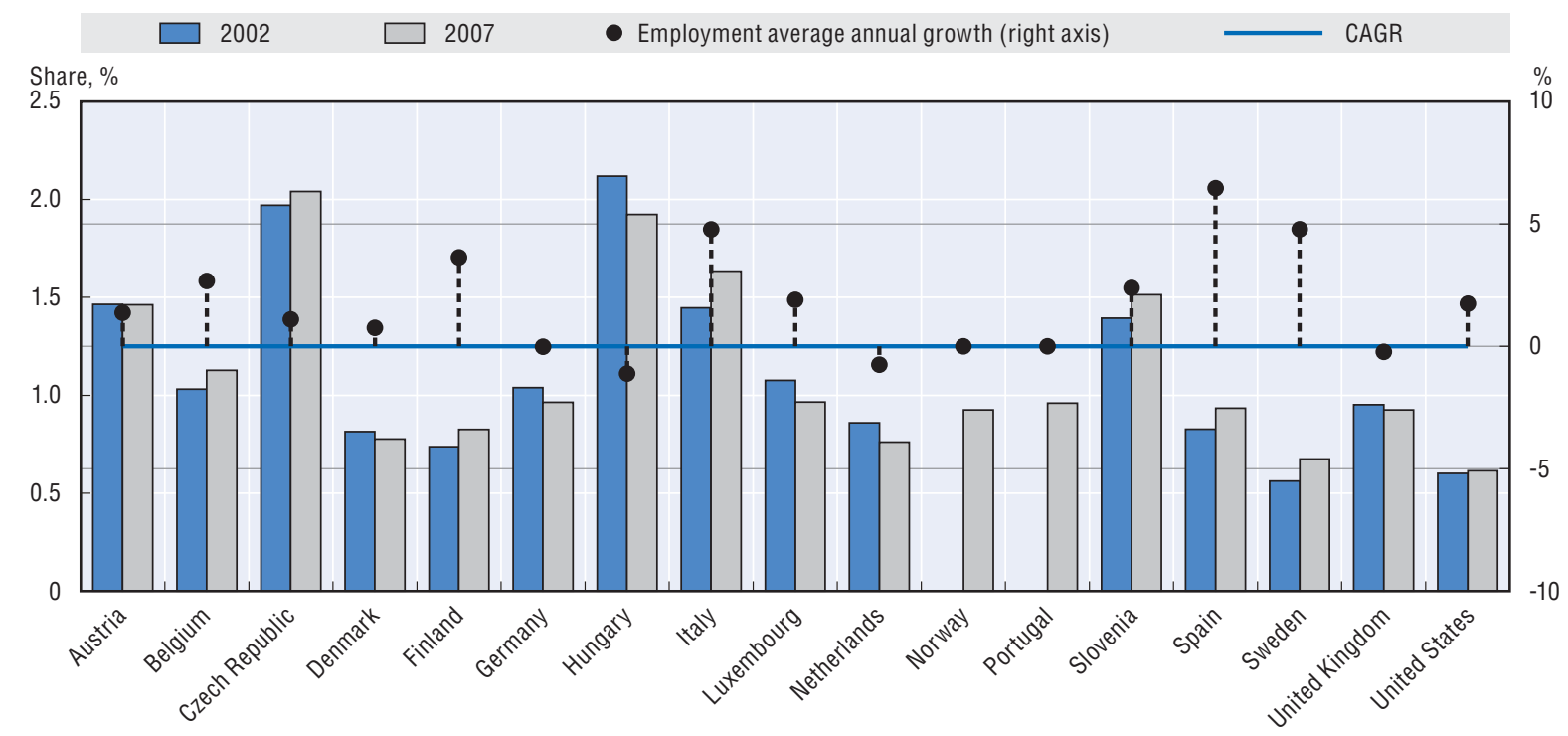

* Total economy corresponds to ISIC Sectors 10 to 74, excluding Sectors 65 to 67 . ISIC 37: Recycling.

ISIC 41: Collection, purification and distribution of water.

ISIC 90: Sewage and refuse disposal, sanitation and similar activities.

Note: Employment figures in STAN are sourced from national accounts and may include adjustments for informal non-registered firms. Source: OECD Structural and Business Statistics (SDBS) Database, and STAN Database for ISIC Sector 90.

StatLink क्ञाs http://dx.doi.org/10.1787/888932384249

Figure 2.3 focuses on the share of green enterprises in total economy and their dynamics. The data come from Eurostat New Cronos Database, and does not comprise Sector 90 (Sewage and refuse disposal, sanitation and similar activities). The figures do however include two four-digit sectors: 25.12 (Retreating), and 51.57 (Wholesale of waste and scrap). Portugal, Greece, and the Slovak Republic stand out, although the trends are not entirely consistent with patterns observed in Figure 2.2. Differences may be partly due to differences in the sectors covered in each graph.

Figure 2.4 compares the rates of birth in a selection of core sectors with rates in the entire economy (excluding the primary sector) and shows marked differences in birth rates 
Figure 2.3. Share of green enterprises (NACE: 25.12, 37, 41 and 51.57) in percentage of total number of enterprises in total economy

2002-2007

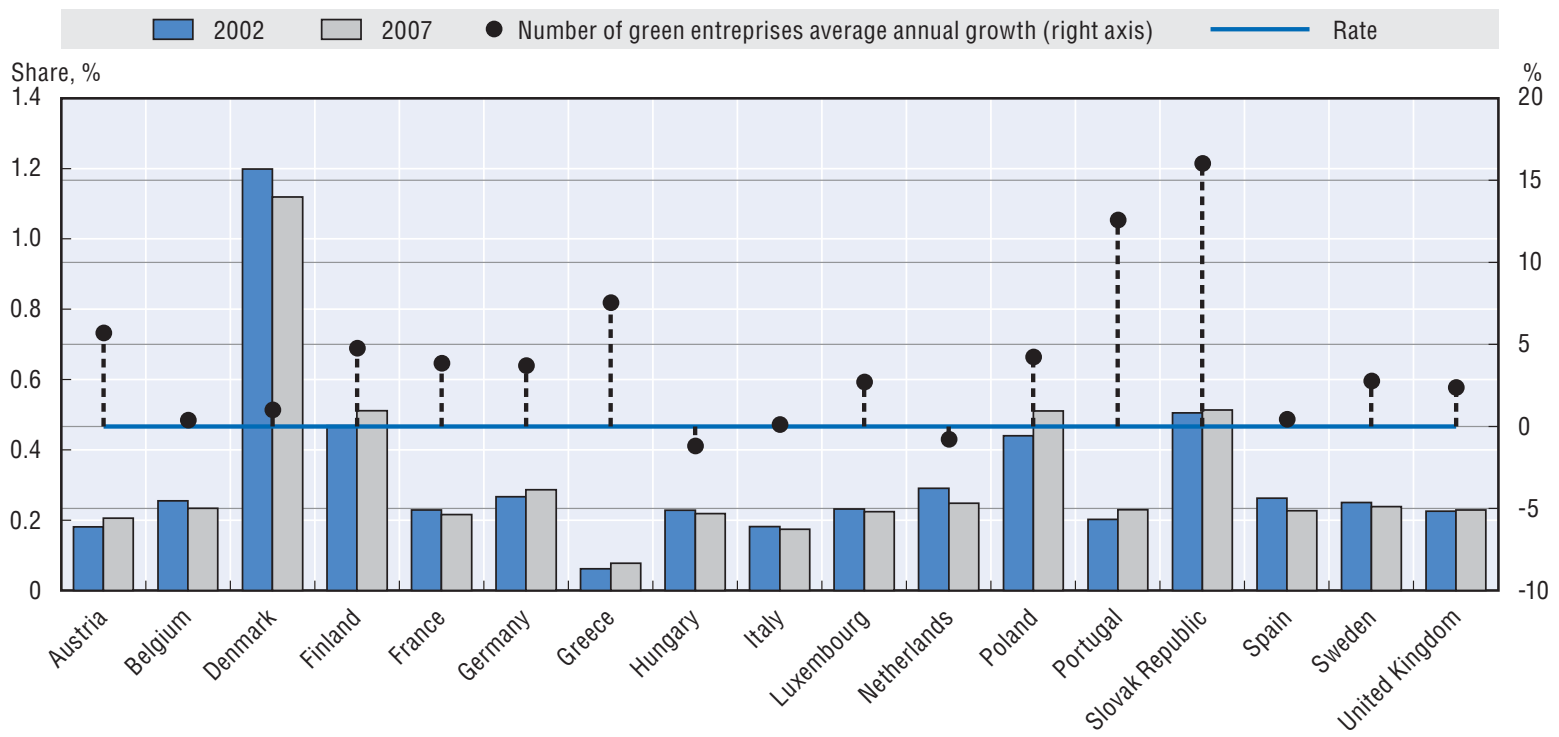

* Total economy corresponds to NACE C to K.

NACE 25.12: Retreating.

NACE 37: Recycling.

NACE 41: Collection, purification and distribution of water.

NACE 51.57: Wholesale of waste and scrap.

Belgium only NACE 37, 41 and 51.57.

Greece only NACE 25.12 and 51.57 .

Belgium, Greece and Poland: Year 2003.

Source: Eurostat New Cronos Database.

\section{Figure 2.4. Business birth rates in a selection of green sectors versus total manufacturing}

2006 or latest data*

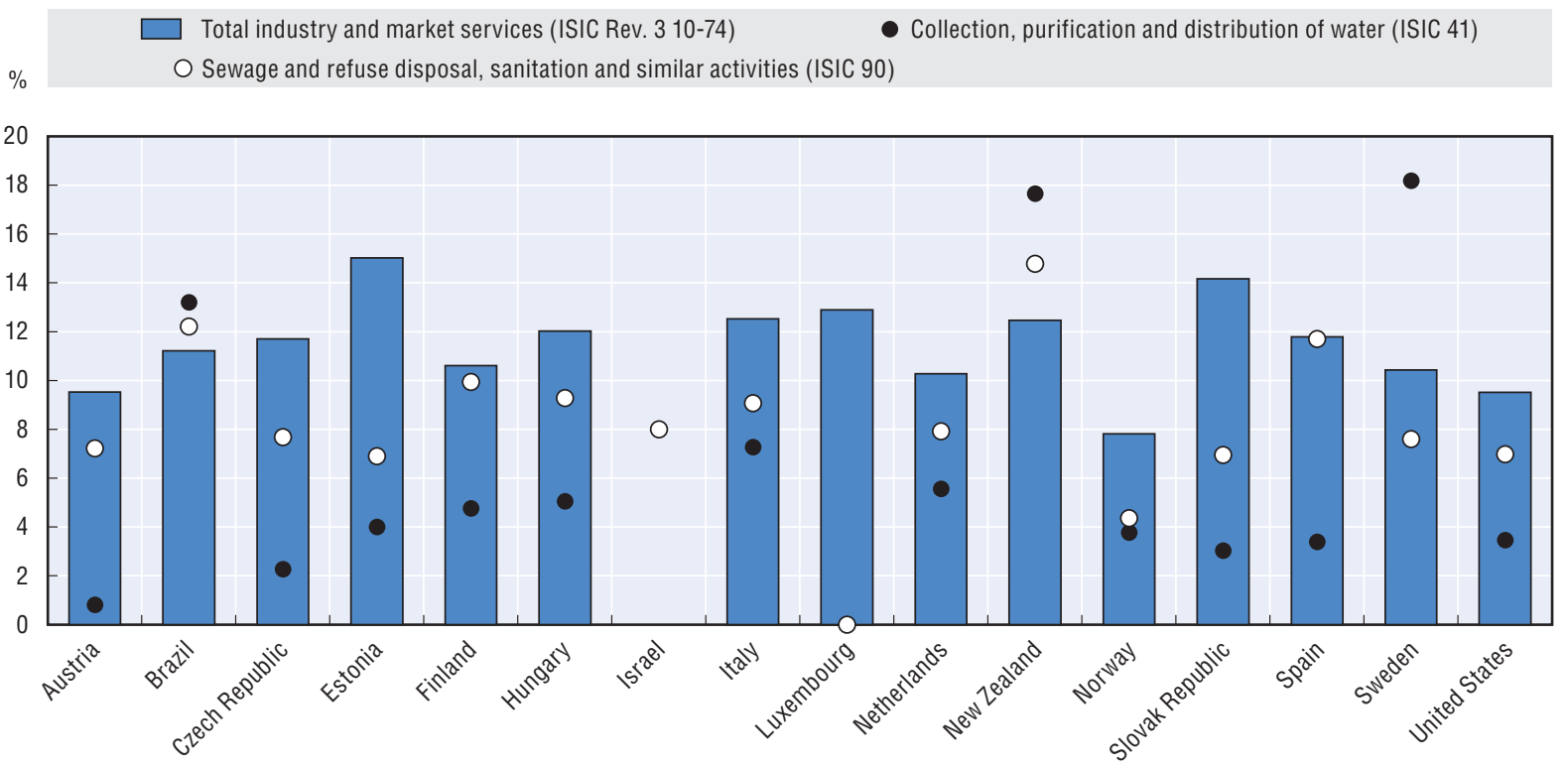

* All employment size class. Employer Birth 2005 data for Czech Republic, Finland, Netherlands, and Slovak Republic. Source: OECD Structural and Business Statistics (SDBS) Database. 
across green sections. Sweden, Finland, Spain and Italy stand out, while some nonEuropean countries such as New Zealand and Brazil display an exceptionally dynamic performance. The deviations in birth rates between industries do not appear to be random. Systematic differences in the nature of activity in each sector may explain much of the cross-country variation in Figure 2.4. The fixed cost of entry, the elasticity of demand, profit margins for new firms are only some of the factors that could impact on the profitability of entrepreneurial activity in an industry. For instance, "Collection, purification and distribution of water" (ISIC 41) records systematically lower birth rates than "Sewage" (ISIC 90) in all countries except the ones with very dynamic performance in ISIC 41.

\subsection{Concluding remarks}

The work presented in this chapter could be seen as a first attempt to separately indentify entrepreneurship dynamics for a group of green sectors that have high policyrelevance. By focusing on core environmental sectors one can produce interesting indicators, but these are however subject to high variation across contries that are difficult to explain. This pilot application nevertheless confirms that it is worth pursuing the effort of looking at diversity within environmental sectors.

The way forward could include a number of important initiatives. The enhancement of coverage of environmental sub-sectors in the existing databases is already scheduled or implemented in many European countries (Eurostat, 2009) and it is also being considered in the revision of the 2003 SEEA (Integrated Environmental and Economic Accounting) of the United Nations, expected in 2012. Similar actions in other OECD countries could prove equally beneficial for policy toward green sectors. Moreover, the use of micro-data in the future should allow for better identification of green activities, and entrepreneurial dynamics. Information at the micro-level will not only improve considerably the consistency of estimates produced. It will also provide the means to answer customized queries, and develop indices of entrepreneurial performance focused on groups of firms, regions, sectors or activities of interest that have been difficult to produce in the past.

\section{Notes}

1. Independently of the definition one uses to delimit green entrepreneurship, the degree to which its fundamental components are present differs among individual cases. An entrepreneur uses green and non-green inputs to produce green and non-green goods. The motivations of a green entrepreneur may not only be green.

2. A product or service was considered "green" based on whether it conserves energy or other natural resources, or reduces pollution (US Department of Commerce, 2010).

\section{References}

Anderson, A. (1998), “Cultivating the garden of eden: Environmental Entrepreneuring”, Journal of Organizational Change Management, 11(2):135-144.

Becker, R.A., and R.J. Shadbegian (2008), “The Green industry - An examination of Environmental products Manufacturing", Center for Economic Studies Discussion Paper, 08-34, Bureau of the Census, Washington.

Brolinson, H.M. Cederlund, and M. Eberhardson (2006), "Environmental goods and services sector in Sweden 2002-2005", Statistics Sweden (SCB), Stockholm.

European Commission (2009), Study on the Competitiveness of the EU eco-industry, within the Framework Contract of Sectoral Competitiveness Studies - ENTR/06/054. Directorate-General for Enterprise and Industry, Brussels.

Eurostat (2009), The environmental goods and services sector, A data collection handbook, Luxembourg. 
Hungarian Central Statistical Office (2005), Towards Environmental Protection Expenditure and Environment Industry Accounts in Hungary - Final Report, Budapest.

Isaak, R. (2005), “The making of the ecopreneur" in Schaper, M. (ed.), "Making ecopreneurs: developing sustainable entrepreneurship", Corporate Social Responsibility, London.

Janssen, L., and G. Vandille (2009), “The Belgian environment industry (1995-2005)”, Federal Planning Bureau Working Paper 7-09, Brussels.

Mansfield, T., and D. Thomas (2005), The Environmental Industry Unit's Analysis of the Sector in 2004. Environmental Industries Unit, DTI, Department for Environment Food and Rural Affairs (Defra), London

OECD (1996), Interim Definition and Classification of the Environment Industry, GD(96)117, Paris.

OECD/Eurostat (1999), The Environmental Goods and Services Industry - Manual for Data Collection and Analysis, Paris.

OECD (2010), Monitoring Progress Towards Green Growth - Ministerial Report on Green Growth Indicators. ENV/EPOC/SE(2010)4, Paris.

Statistics Canada (2007), Environment Industry: Business Sector - 2002 (revised) and 2004. Catalogue No. 16F0008, Ottawa.

US Department of Commerce (2010), Measuring the Green Economy, Washington.

United Nations Environmental Program (2009), Global Green New Deal, An Update for the G20 Pittsburgh Summit. Paris

United Nations Department of Economic and Social Affairs (2010), Outcome paper for global consultation, Issue 5: Environmental Goods and Services Sector, New York.

Van Rossum, M., and S. Schenau (2006), Economic Indicators for the Eco-Industries in the Netherlands, 2003. Statistics Netherlands (CBS), The Hague.

Volery, T. (2002), Ecopreneurship: Rationale, current issues and future challenges, in Conference Proceedings, Rencontres de l'Université St.-Gallen. 


\begin{abstract}
ANNEX I.A
Example of Environmental Sectors

The example comes from OECD/Eurostat (1999). Statistics Canada used a similar breakdown, based on the classification presented in OECD (1996), to survey the environmental goods and services industry for the year 1995.* The breakdown presented here has been re-organized to match the revisions to OECD (1996). This breakdown is also the basis for the detailed correspondence with HS codes (Harmonised System Codes
\end{abstract} Commodity Classification).

\title{
A. Pollution management group
}

Production of equipment and specific materials for:

1. Air pollution control

1.1. Air-handling equipment

1.2. Catalytic converters

1.3. Chemical recovery systems

1.4. Dust collectors

1.5. Separators, precipitators

1.6. Incinerators, scrubbers

1.7. Odour control equipment

\section{Wastewater management}

2.1. Aeration systems

2.2. Chemical recovery systems

2.3. Biological recovery systems

2.4. Gravity sedimentation systems

2.5. Oil/water separation systems

2.6. Screens, strainers

2.7. Sewage treatment

2.8. Water pollution control, wastewater reuse equipment

2.9. Water handling goods and equipment

\footnotetext{
* See Statistics Canada (1997), Environment Industry, 1995, Preliminary Data.
} 
3. Solid waste management

3.1. Hazardous waste storage and treatment equipment

3.2. Waste collection equipment

3.3. Waste disposal equipment

3.4. Waste handling equipment

3.5. Waste separation equipment

3.6. Recycling equipment

3.7. Incineration equipment

4. Remediation and clean-up of soil and water

4.1. Absorbents

4.2. Cleaning-up

4.3. Water treatment equipment

5. Noise and vibration abatement

5.1. Mufflers, silencers

5.2. Noise deadening material

5.3. Vibration control systems

5.4. Highway barriers

6. Environmental monitoring, analysis and assessment

6.1. Measuring and monitoring equipment

6.2. Sampling systems

6.3. Process and control equipment

6.4. Data acquisition equipment

6.5. Other instruments, machines

7. Other

Provision of services for:

8. Air pollution control

8.1. Emission monitoring

8.2. Assessment/evaluation/planning

9. Wastewater management

9.1. Sewage treatment systems

9.2. Wastewater reuse systems

9.3. Water handling systems

10. Solid waste management

10.1. Emergency response and spills clean-up

10.2. Waste handling, collection, transport and disposal 
10.3. Operation of sites

10.4. Recycling (sorting, baling, cleaning)

10.5. Operation of recycling plants (materials recovery facilities)

10.6. Hazardous waste management

10.7. Medical waste management

11. Remediation and clean-up of soil and water

11.1. Cleaning-up

11.2. Operation of water treatment facilities

11.3. Industrial services (cleaning for facilities and tanks)

12. Noise and vibration abatement

12.1. Assessment/monitoring

13. Environmental research and development

13.1. Clean processes

13.2. End-of-pipe pollution abatement control

14. Environmental contracting and engineering

14.1. Engineering design/specification/project management

14.2. Biological and ecosystem studies

14.3. Environment impact assessment, audits

14.4. Water treatment

14.5. Environmental planning

14.6. Risk and hazard assessment

14.7. Laboratory and field services

14.8. Environmental economics

14.9. Legal services (environmental law)

14.10. Environmental management

15. Analytical services, data collection, analysis and assessment

15.1. Measuring and monitoring

15.2. Sampling

15.3. Process and control

15.4. Data acquisition

15.5. Others

16. Education, training, information

16.1. Environmental education and training

16.2. Environmental information searching services

16.3. Environmental data managemeìnt and analysis 
17. Other

\section{Construction and installation for:}

18. Air pollution control

19. Wastewater management

19.1. Sewer systems

19.2. Wastewater treatment plant

20. Solid waste management

20.1. Solid waste treatment, storage and disposal

20.2. Hazardous waste management

20.3. Recycling

21. Remediation and clean-up of soil and water

22. Noise and vibration abatement

22.1. Highway barriers

23. Environmental monitoring, analysis and assessment

24. Other

B. Cleaner technologies and products group

Production of equipment, technology, specific materials or services for:

1. Cleaner/resource-efficient technologies and processes

1.1. Components of cleaner/resource-efficient technologies

1.2. Biotechnology

2. Cleaner/resource-efficient products

2.1. Components of cleaner/resource-efficient products

\section{Resource management group}

Production of equipment, technology, specific materials, services, construction and installation for:

1. Indoor air pollution control

2. Water supply

2.1. Potable water treatment

2.2. Water purification systems

2.3. Potable water supply and distribution

3. Recycled materials

3.1. Recycled paper

3.2. Other recycled products 
4. Renewable energy plant

4.1. Solar

4.2. Wind

4.3. Tidal

4.4. Geothermal

4.5. Other

5. Heat/energy saving and management

6. Sustainable agriculture and fisheries

7. Sustainable forestry

7.1. Reforestation

7.2. Forest management

8. Natural risk management

9. Eco-tourism

10. Other

10.1. Conservation and resource management 
PART II

\section{Entrepreneurship Indicators}





\section{STRUCTURAL INDICATORS}

ON THE ENTERPRISE POPULATION

1. Enterprises by size class

2. Employment by size class

3. Value added by size class

4. Exports by size class 
The distribution of the business population by size provides basic information on the structure of the business sector. It is related to the distribution of businesses by activity sector and age and to the size of the internal market. It is of particular use, together with other business statistics by size class, to policy makers wishing to focus on the role in the economy of entreprises of different sizes.

\section{Definition}

An enterprise is a legal entity possessing the right to conduct business on its own, for example to enter into contracts, own property, incur liabilities for debts and establish bank accounts. It may consist of one or more local units or establishments corresponding to different production units situated in a geographically separate place and in which one or more persons work for the enterprise to which they belong.

The basis for size classification is the total number of persons employed, i.e. persons who worked in or for the concerned unit during the reference year.

Figures 1.1 and 1.2 show the number of enterprises in each size class, as a percentage of the total number of enterprises.

\section{Comparability}

All countries present information using the enterprise as the statistical unit except Japan, Korea and Mexico, which use establishments. As most enterprises in these countries consist of only one establishment, comparability issues are not expected to be significant.

For Ireland, only enterprises with three or more persons employed are covered, while the data for Japan and Korea do not include establishments with fewer than four and five persons employed, respectively. For the United States, employment in enterprises refers to the number of employees and not the number of persons employed.

The size-class breakdown used, i.e. 1-9, 10-19, 20-49, 50-249, $250+$, provides for the best comparability given the varying data collection practices across countries. Some countries use different conventions: the size class "20-49" actually refers to "20-99" for the United States; the size class "50-249" refers to "50-199" for Australia and Korea, "50-99" for New Zealand and "100-499" for the United States; and the size class "250+" refers to "200+" for Australia and Korea, "100+" for New Zealand and "500+" for the United States.

Data cover market economy, excluding financial intermediation; for Brazil, Ireland, Israel, Japan, Korea, Luxembourg and the Slovak Republic they cover manufacturing sectors only. This may result in a lower proportion of micro-enterprises for these countries, since the average size of entreprises is typically lower in the services sector.

The reference year of the data is 2007, with the exception of Australia, Korea and United States (2006), Iceland (2005) and Mexico (2003).

In Figure 1.1, the high share of enterprises with 1 to 9 persons employed does not allow to visually compare the shares of the various size classes above 10 persons employed. For this reason, a second figure is proposed, focusing on enterprises with more than 10 persons employed.

\section{Highlights}

The business population is composed, in any country, of a predominant number of micro-enterprises, i.e. firms with less than ten employees.

\section{Source/Online database}

OECD Structural and Demographic Business Statistics (SDBS) Database.

http://dx.doi.org/10.1787/sdbs-data-en

\section{For further reading}

OECD (2010), Structural and Demographic Business Statistics, OECD Publishing, Paris.

http://dx.doi.org/10.1787/9789264072886-en

Ahmad N. (2007), The OECD's Business Statistics Database and Publication, Paper presented at the Structural Business Statistics Expert Meeting, Paris, 10-11 May 2007.

www.oecd.org/dataoecd/59/34/38516035.pdf

Information on data for Israel:

http://dx.doi.org/10.1787/888932315602 


\section{STRUCTURAL INDICATORS ON THE ENTERPRISE POPULATION}

Figure 1.1. Enterprises by size class in 2007

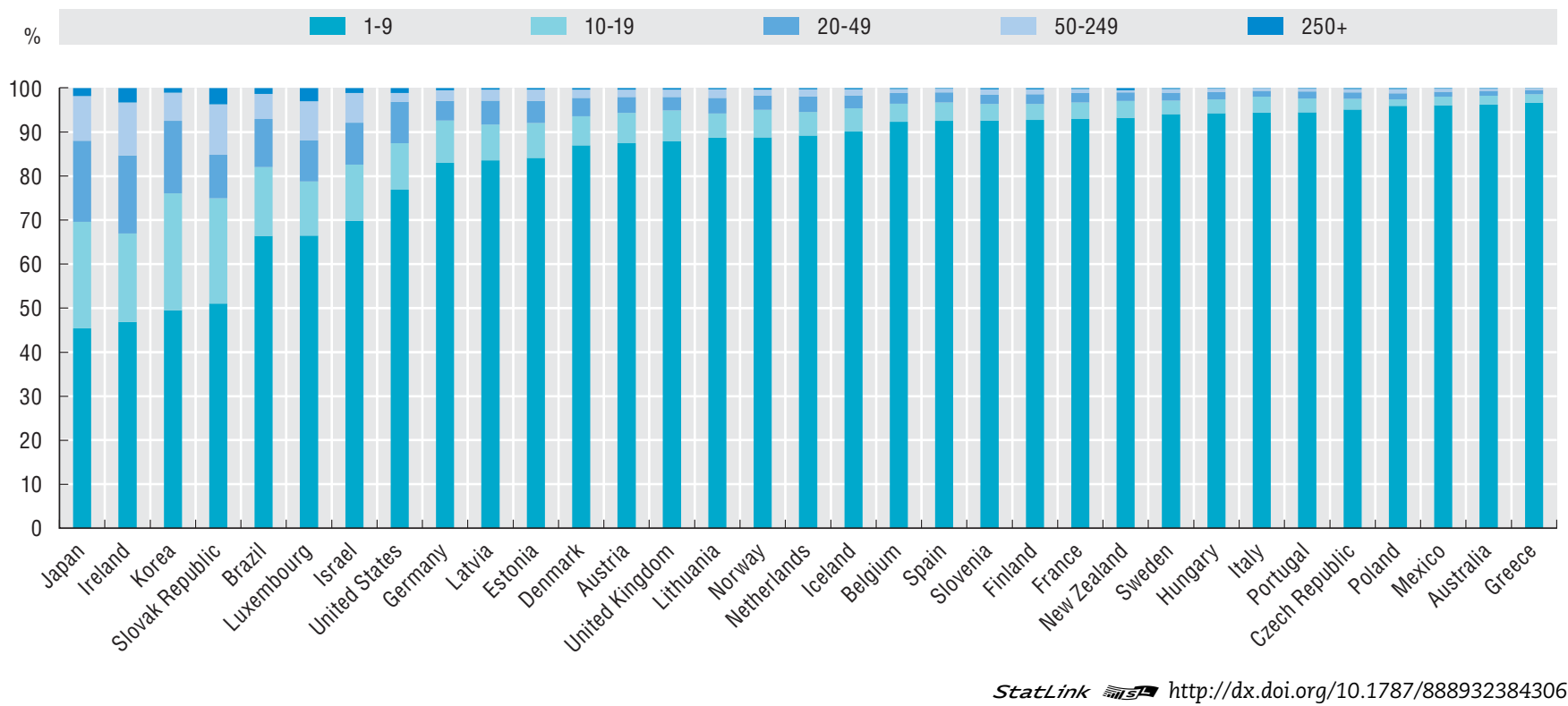

Figure 1.2. Employer enterprises with 10 persons engaged or more, 2007

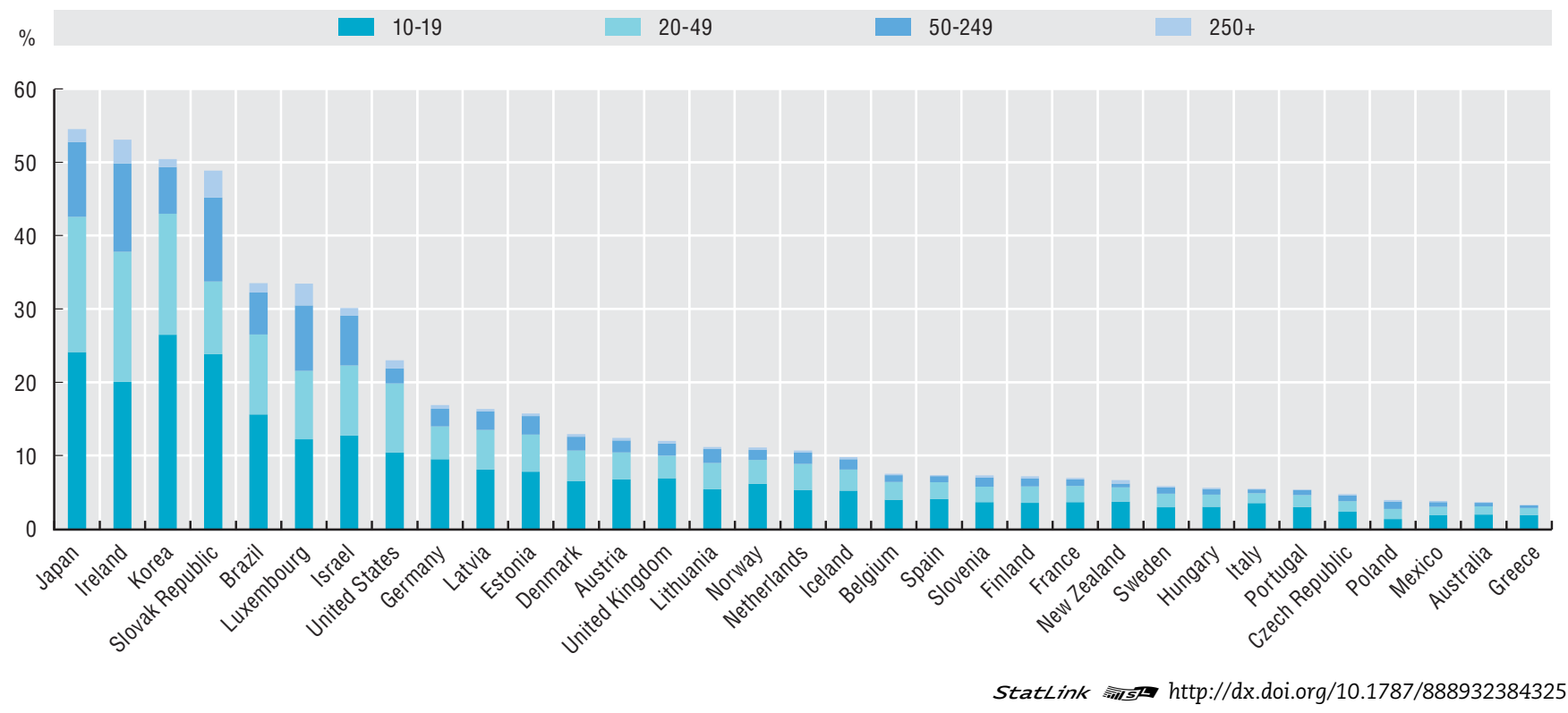




\section{Amployment by size class}

The breakdown of employment by size class describes how total employment is distributed among enterprises of different sizes. It provides important information on the ability of firms of various sizes to foster employment.

\section{Definition}

The total number of persons employed is defined as the total number of persons who worked in or for the concerned unit during the reference year.

Total employment excludes directors of incorporated enterprises and members of shareholders' committees who are paid solely for their attendance at meetings, labour force made available to the concerned unit by other units and charged for, persons carrying out repair and maintenance work in the unit on the behalf of other units, and home workers. It also excludes persons on indefinite leave, military leave or those whose only remuneration from the enterprise is by way of a pension.

Unless otherwise stated, data are expressed as a percentage of the total number of persons employed in market industry. Total employment by country is shown in Table 2.1 .

\section{Comparability}

Data for all countries refer to the number of persons employed, with the exception of Brazil, New Zealand and the United States for which it refers to the number of employees.

All countries present information using the enterprise as the statistical unit except Japan, Korea and Mexico, which use establishments.

For Ireland, only enterprises with three or more persons employed are covered, while the data for Japan and Korea do not include establishments with fewer than four and five persons employed respectively.

The size-class breakdown used, i.e. 1-9, 10-19, 20-49, 50-249, $250+$, provides for the best comparability given the varying data collection practices across countries. Some countries use slightly different conventions: the size class "20-49" actually refers to "20-99" for the United States; the size class "50-249" refers to "50-199" for Australia, "50-99" for New Zealand and "100-499" for the United States; and the size class "250+" refers to "200+" for Australia, "100+" for New Zealand and "500+" for the United States.

Data cover the market economy, excluding financial intermediation; for Brazil, Ireland, Israel, Japan, Korea, Luxembourg and the Slovak Republic they cover manufacturing sectors only. This may result in a lower proportion of employment in micro-enterprises for these countries, since the average size of entreprises is typically lower in the services sector.

The reference year of the data is 2007, with the exception of Australia and Korea (2006), and Mexico (2003).

\section{Highlights}

There are significant variations across countries concerning the distribution of employment among entreprises of different sizes. In Greece, Italy, Mexico and Portugal more than $40 \%$ of employment is in enterprises with less than ten persons employed, while the same category of firms accounts for less than $20 \%$ of total empoyment in Germany.

\section{Source/Online database}

OECD Structural and Demographic Business Statistics (SDBS) Database.

http://dx.doi.org/10.1787/sdbs-data-en

\section{For further reading}

OECD (2010), Structural and Demographic Business Statistics, OECD publishing, Paris.

http://dx.doi.org/10.1787/9789264072886-en

Ahmad N. (2007), The OECD's Business Statistics Database and Publication, Paper presented at the Structural Business Statistics Expert Meeting, Paris, 10-11 May 2007.

www.oecd.org/dataoecd/59/34/38516035.pdf

Information on data for Israel:

http://dx.doi.org/10.1787/888932315602 


\section{STRUCTURAL INDICATORS ON THE ENTERPRISE POPULATION}

Figure 2.1. Employment by size class in 2007

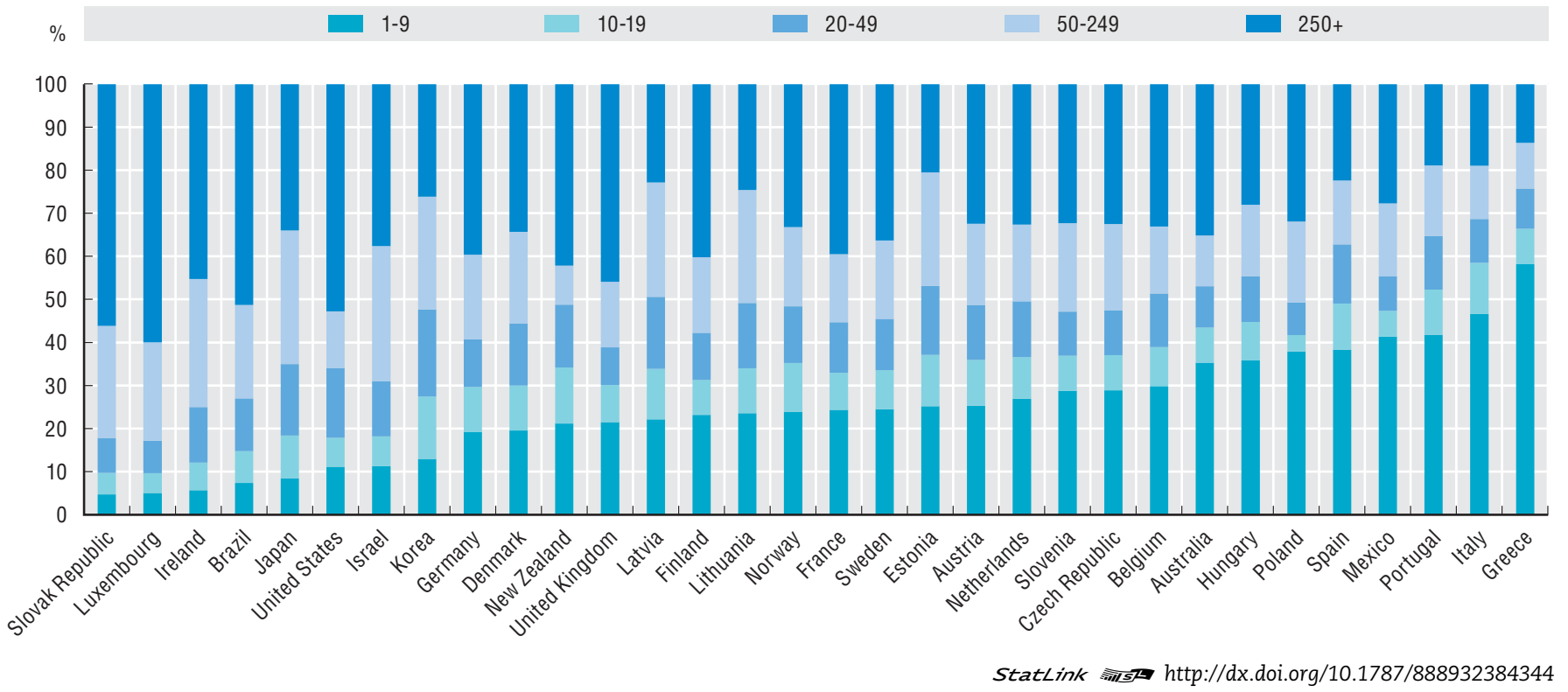

Table 2.1. Number of persons employed in $\mathbf{2 0 0 7}$

\begin{tabular}{|c|c|c|c|c|c|c|c|}
\hline Country & Employment & Country & Employment & Country & Employment & Country & Employment \\
\hline Slovak Republic (manufacturing) & 424295 & Germany & 22199161 & France & 15104252 & Australia & 6401000 \\
\hline Luxembourg (manufacturing) & 37254 & Denmark & 1802120 & Sweden & 2873836 & Hungary & 2534548 \\
\hline Ireland (manufacturing) & 223612 & New Zealand (number of employees) & 1215528 & Estonia & 430345 & Poland & 8248415 \\
\hline $\begin{array}{l}\text { Brazil (number of employees, } \\
\text { manufacturing) }\end{array}$ & 6955162 & United Kingdom & 18136892 & Austria & 2452145 & Spain & 14260730 \\
\hline Japan (manufacturing) & 8621393 & Latvia & 668605 & Netherlands & 5034991 & Mexico & 13110232 \\
\hline United States (number of employees) & 71505608 & Finland & 1292748 & Slovenia & 608448 & Portugal & 3324727 \\
\hline Israel (manufacturing) & 360744 & Lithuania & 983249 & Czech Republic & 3613318 & Italy & 15589199 \\
\hline Korea (manufacturing) & 2910935 & Norway & 1042387 & Belgium & 2512687 & Greece & 2600028 \\
\hline
\end{tabular}


Value added by enteprise size class describes the contribution of enterprises of different sizes to total value added of the business sector. This indicator contributes to improve understanding of the types of businesses that generate more value added in the economy.

\section{Definitions}

Value added corresponds to the difference between production and any intermediate consumption, where total intermediate consumption should always be valued at purchasers' prices. The valuation of value added can be made according to any of the following four valuations: factor costs, basic prices, market prices and producers' prices, depending on the treatment applied to indirect taxes and subsidies.

Data in this section present the value added in each size class as a percentage of the value added of all enterprises.

\section{Comparability}

Data refer to value added at factor costs in the EU countries and value added at basic prices for Australia, Japan and Korea. All countries present information using the enterprise as the statistical unit except Japan, Korea and Mexico, which use establishments.

For Ireland, only enterprises with three or more persons employed are covered, while the data for Japan and Korea do not include establishments with fewer than four and five persons employed respectively.
The size class breakdown used provides for the best comparability across countries given the varying data collection practices across countries. Some countries use different conventions. Data shown for "50-249" actually refer to "50-199" for Australia, and Korea; data shown for "250+" actually refer to "200+" for Australia and Korea.

Data cover the market economy, excluding financial intermediation. They cover only manufacturing sectors for Brazil, Hungary, Ireland, Israel, Japan, Korea, Luxembourg and the Slovak Republic.

Data refer to 2007, with the exception of Australia, and Korea (2006) and Mexico (2003).

\section{Highlights}

In most countries, enterprises with more than 250 persons employed account for a considerable part of the value added of the business sector, despite representing a small share of the business population.

\section{Source/Online database}

OECD Structural and Demographic Business Statistics (SDBS) Database.

http://dx.doi.org/10.1787/sdbs-data-en

\section{For further reading}

OECD (2010), Structural and Demographic Business Statistics, OECD Publishing, Paris.

http://dx.doi.org/10.1787/9789264072886-en

Information on data for Israel:

http://dx.doi.org/10.1787/888932315602 


\section{STRUCTURAL INDICATORS ON THE ENTERPRISE POPULATION}

Figure 3.1. Value added by size class in 2007

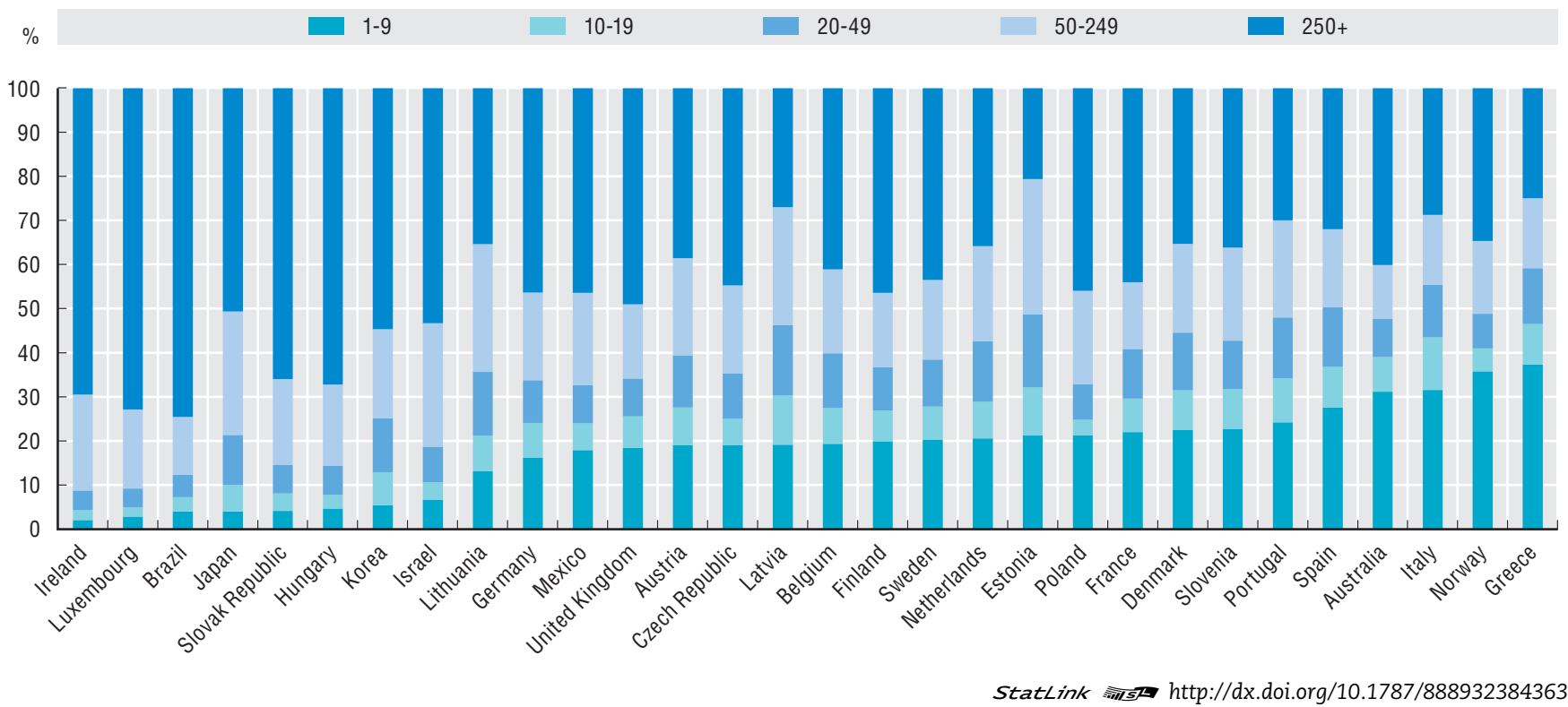

Table 3.1. Value added by size class in 2007 , as a percentage of the value added of all enterprises

\begin{tabular}{|c|c|c|c|c|c|}
\hline Country & $1-9$ & $10-19$ & $20-49$ & $50-249$ & $250+$ \\
\hline Ireland & 2.0 & 2.3 & 4.4 & 21.8 & 69.5 \\
\hline Luxembourg & 2.8 & 2.1 & 4.3 & 17.9 & 72.9 \\
\hline Brazil & 3.9 & 3.2 & 5.1 & 13.2 & 74.6 \\
\hline Japan & 4.0 & 6.0 & 11.4 & 28.0 & 50.7 \\
\hline Slovak Republic & 4.1 & 4.0 & 6.4 & 19.5 & 66.0 \\
\hline Hungary & 4.6 & 3.1 & 6.6 & 18.4 & 67.3 \\
\hline Korea & 5.4 & 7.4 & 12.3 & 20.2 & 54.7 \\
\hline Israel & 6.6 & 3.9 & 8.1 & 28.0 & 53.3 \\
\hline Lithuania & 13.1 & 8.0 & 14.5 & 29.0 & 35.4 \\
\hline Germany & 16.1 & 8.0 & 9.7 & 19.9 & 46.3 \\
\hline Mexico & 17.8 & 6.2 & 8.7 & 20.9 & 46.4 \\
\hline United Kingdom & 18.4 & 7.2 & 8.5 & 16.9 & 49.0 \\
\hline Austria & 19.1 & 8.5 & 11.9 & 22.0 & 38.5 \\
\hline Czech Republic & 19.1 & 6.0 & 10.3 & 19.9 & 44.7 \\
\hline Latvia & 19.1 & 11.2 & 15.9 & 26.8 & 27.0 \\
\hline Belgium & 19.3 & 8.1 & 12.4 & 19.1 & 41.1 \\
\hline Finland & 19.9 & 7.0 & 9.8 & 16.9 & 46.4 \\
\hline Sweden & 20.3 & 7.5 & 10.7 & 18.1 & 43.5 \\
\hline Netherlands & 20.6 & 8.3 & 13.7 & 21.6 & 35.8 \\
\hline Estonia & 21.2 & 10.9 & 16.5 & 30.8 & 20.6 \\
\hline Poland & 21.3 & 3.5 & 8.1 & 21.2 & 46.0 \\
\hline France & 22.0 & 7.6 & 11.2 & 15.2 & 44.0 \\
\hline Denmark & 22.4 & 9.0 & 13.0 & 20.2 & 35.3 \\
\hline Slovenia & 22.6 & 9.1 & 11.0 & 21.1 & 36.2 \\
\hline Portugal & 24.2 & 10.0 & 13.8 & 22.0 & 30.0 \\
\hline Spain & 27.5 & 9.2 & 13.5 & 17.7 & 32.0 \\
\hline Australia & 31.1 & 7.9 & 8.6 & 12.3 & 40.1 \\
\hline Italy & 31.5 & 12.0 & 11.9 & 15.9 & 28.7 \\
\hline Norway & 35.8 & 5.2 & 7.9 & 16.5 & 34.6 \\
\hline Greece & 37.3 & 9.2 & 12.6 & 15.9 & 24.9 \\
\hline
\end{tabular}




\section{STRUCTURAL INDICATORS ON THE ENTERPRISE POPULATION}

\section{Fxports by size class}

Exports by enteprise size class describe the contribution of enterprises of different sizes to total exports. This indicator provides information on the profile of exporters.

\section{Definitions}

Exports refer to the outward flows of goods from one country to another.

Data in this section present the exports of enterprises in each size class as a percentage of exports of all enterprises.

\section{Comparability}

Trade statistics by enterprise characteristics are developed by establishing a linkage between trade registers and business registers.

Data are compiled according to the reporting trade system "special trade" for EU member states, while Canada and the United States apply the "general trade" system. The main difference between special and general trade is linked to the inclusion or not of the trade involving Customs warehouse.
For EU member states, data on intra-EU and extra-EU exports are treated separately, owing to different data collection systems and thresholds. Total exports are compiled by adding intra-EU and extra-EU exports.

\section{Highlights}

In the majority of countries, more than $50 \%$ of total exports are accounted for by large firms, with values being particularly high for the United States, Hungary and Finland.

\section{Source/Online databases}

OECD Trade by Enterprise Characteristics Database (TEC).

\section{For further reading}

OECD (2011), "Selling to Foreign Markets: a Portrait of OECD Exporters", Statistics Brief No. 16. www.oecd.org/dataoecd/28/27/47014723.pdf

OECD (2010), Structural and Demographic Business Statistics, OECD Publishing, Paris.

http://dx.doi.org/10.1787/9789264072886-en

Eurostat (2007), “External Trade by Enterprise Characteristics”, Luxembourg. 


\section{STRUCTURAL INDICATORS ON THE ENTERPRISE POPULATION}

Figure 4.1. Exports by size class in 2007

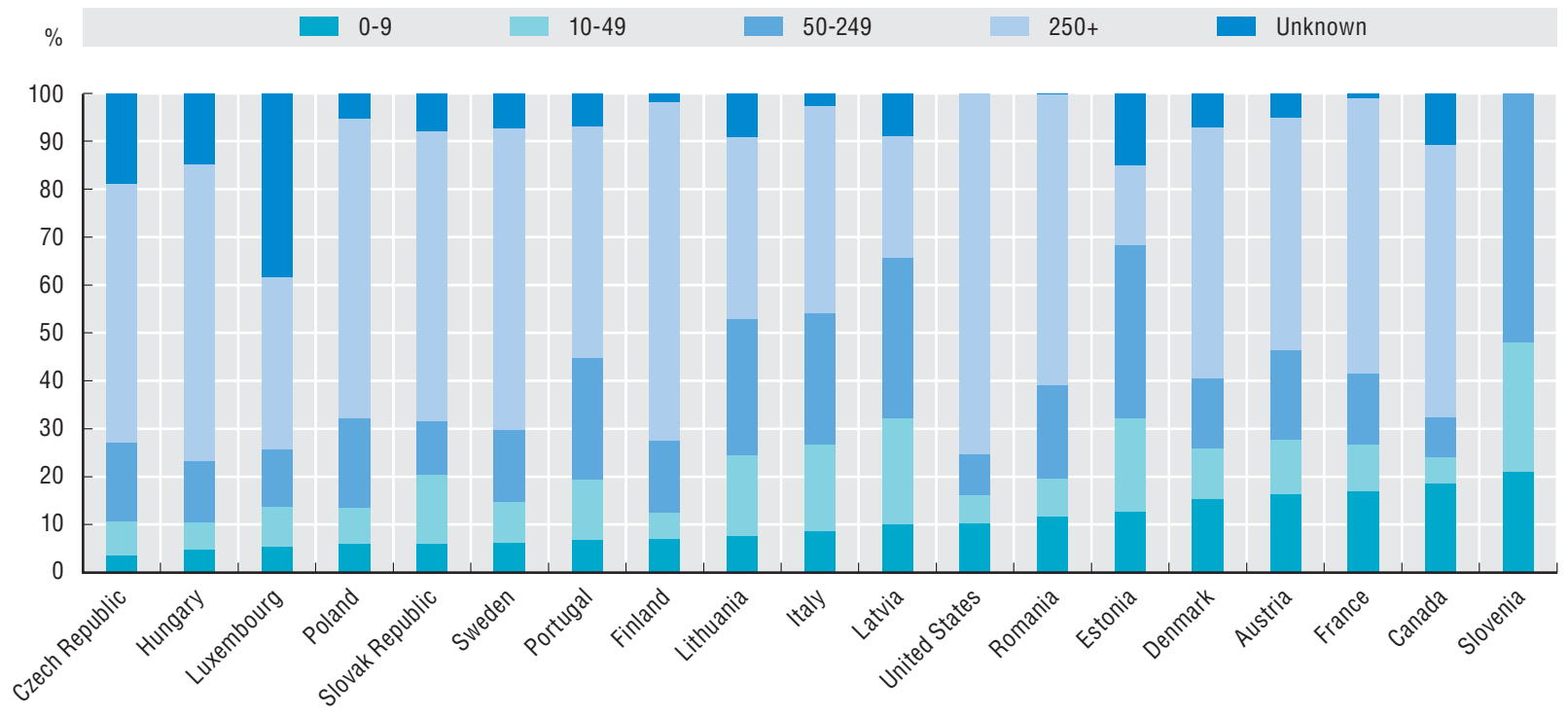

StatLink क्गाड़ http://dx.doi.org/10.1787/888932384382

Table 4.1. Exports by size class in $\mathbf{2 0 0 7}$ as a percentage of exports of all enterprises

\begin{tabular}{|c|c|c|c|c|c|}
\hline & $0-9$ & $10-49$ & $50-249$ & $250+$ & Unknowr \\
\hline Czech Republic & 3.6 & 7.1 & 16.4 & 54.1 & 18.8 \\
\hline Hungary & 4.9 & 5.7 & 12.8 & 61.9 & 14.6 \\
\hline Luxembourg & 5.5 & 8.2 & 11.9 & 36.1 & 38.3 \\
\hline Poland & 6.0 & 7.5 & 18.8 & 62.4 & 5.3 \\
\hline Slovak Republic & 6.1 & 14.4 & 11.2 & 60.6 & 7.8 \\
\hline Sweden & 6.3 & 8.5 & 14.9 & 63.0 & 7.3 \\
\hline Portugal & 6.9 & 12.5 & 25.4 & 48.4 & 6.8 \\
\hline Finland & 7.0 & 5.6 & 14.9 & 70.7 & 1.7 \\
\hline Lithuania & 7.8 & 16.6 & 28.6 & 37.9 & 9.1 \\
\hline Italy & 8.7 & 18.1 & 27.3 & 43.2 & 2.7 \\
\hline Latvia & 10.1 & 22.1 & 33.6 & 25.2 & 8.9 \\
\hline United States & 10.3 & 5.9 & 8.6 & 75.2 & 0.0 \\
\hline Romania & 11.8 & 7.8 & 19.5 & 60.7 & 0.2 \\
\hline Estonia & 12.9 & 19.3 & 36.3 & 16.5 & 15.0 \\
\hline Denmark & 15.4 & 10.5 & 14.7 & 52.3 & 7.0 \\
\hline Austria & 16.4 & 11.2 & 18.9 & 48.5 & 5.0 \\
\hline France & 16.9 & 9.9 & 14.7 & 57.6 & 0.9 \\
\hline Canada & 18.5 & 5.7 & 8.3 & 56.8 & 10.8 \\
\hline Slovenia & 21.0 & 27.1 & 51.9 & 0.0 & 0.0 \\
\hline
\end{tabular}


4.46

.13

300238

3.72

$17 \sin ^{2} 189$

$$
\beta
$$

$2 \pi$

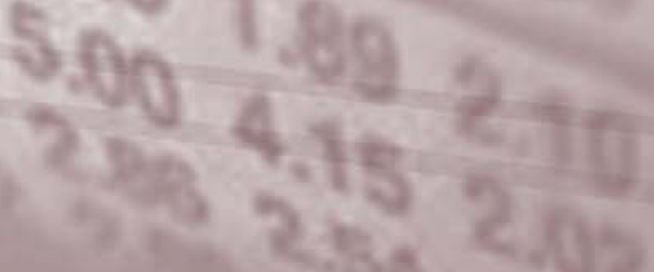

$$
\begin{aligned}
& \text { is ?.05 } \\
& \text { पर } 309
\end{aligned}
$$

8

$\sqrt{4}+2$

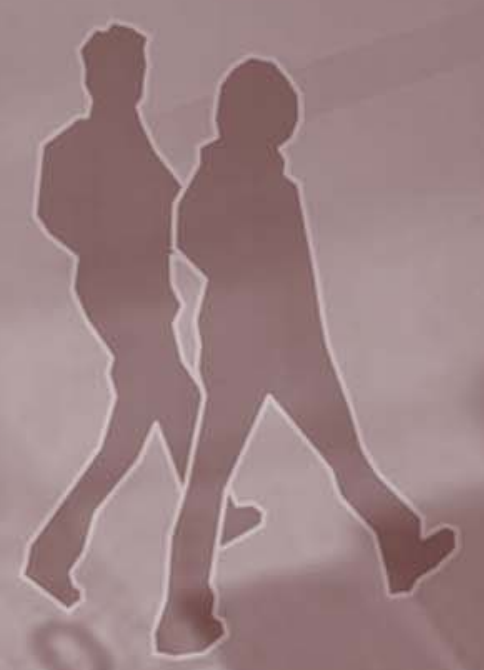

is 


\section{ENTERPRISE BIRTH, DEATH AND SURVIVAL}

5. Birth rate of employer enterprises

6. Death rate of employer enterprises

7. Churn rate of employer enterprises

8. Survival rate of employer enterprises 


\section{Birth rate of employer enterprises}

The birth of new enterprises is a key indicator of business dynamism. It reflects an important dimension of entrepreneurship in a country, namely the capacity to start up entirely new businesses.

Employer enterprises are economically more relevant than non-employer firms and more closely related to the notion of entrepreneurship as a driver of job creation and innovation.

\section{Definition}

An employer enterprise birth refers to the birth of an enterprise with at least one employee. The population of employer enterprise births consists first of "new" enterprise births, i.e. new enterprises reporting at least one employee in the birth year; and second, enterprises that existed before the year under consideration but were then below the threshold of one employee, and that reported 1 or more employees in the current, i.e. birth, year.

Employer enterprise births do not include entries into the population due to: mergers, break-ups, split-off or restructuring of a set of enterprises. They also exclude entries into a sub-population resulting only from a change of activity.

The employer enterprise birth rate corresponds to the number of births of employer enterprises as a percentage of the population of active enterprises with at least one employee.

\section{Comparability}

"Employer" indicators are found to be more relevant for international comparisons than indicators covering all enterprises, as the latter are sensitive to the coverage of business registers. In many countries, the main sources of data used in business registers are administrative tax and employment registers, meaning that often only businesses above a certain turnover and/or employment threshold are captured. An economy with relatively high thresholds would therefore be expected to have lower birth statistics than similar economies with lower thresholds. An additional complication relates to changes in thresholds over time. Monetary based thresholds change over time in response to e.g. inflation and fiscal policy, both of which can be expected to affect comparisons of birth rates across countries and over time. The use of the one-employee thresholds improve comparability, as it excludes very small units, which are the most subject to threshold variations.

The concept of employer enterprise birth itself is not without problems. Many countries have sizeable populations of self-employed. If a country creates incentives for the selfemployed to become employees of their own company the total number of employer enterprise births will increase. This can distort comparisons over time and across countries, even if from an economic and entrepreneurial perspective little has changed.

Data presented refer to the whole population of employer enterprises, with the exception of Canada, for which data refer to employer enterprises with less than 250 employees.

\section{Highlights}

Birth rates of employer enterprises are higher in the services sector than in manufacturing. The new firms created employ typically 1 to 4 employees, while few start with more than 10 employees.

\section{Source/Online database}

OECD Structural and Demographic Business Statistics (SDBS) Database.

http://dx.doi.org/10.1787/sdbs-data-en

\section{For further reading}

OECD (2010), Structural and Demographic Business Statistics, OECD Publishing, Paris.

http://dx.doi.org/10.1787/9789264072886-en

Eurostat/OECD (2007), Eurostat-OECD Manual on Business Demography Statistics, OECD, Paris.

Ahmad, N. (2006), “A Proposed Framework For business Demography Statistics", OECD Statistics Working Papers, 2006/3, OECD Publishing, Paris.

http://dx.doi.org/10.1787/145777872685

Information on data for Israel:

http://dx.doi.org/10.1787/888932315602 
Figure 5.1. Employer enterprise birth rates in all industries, 2005 to 2007

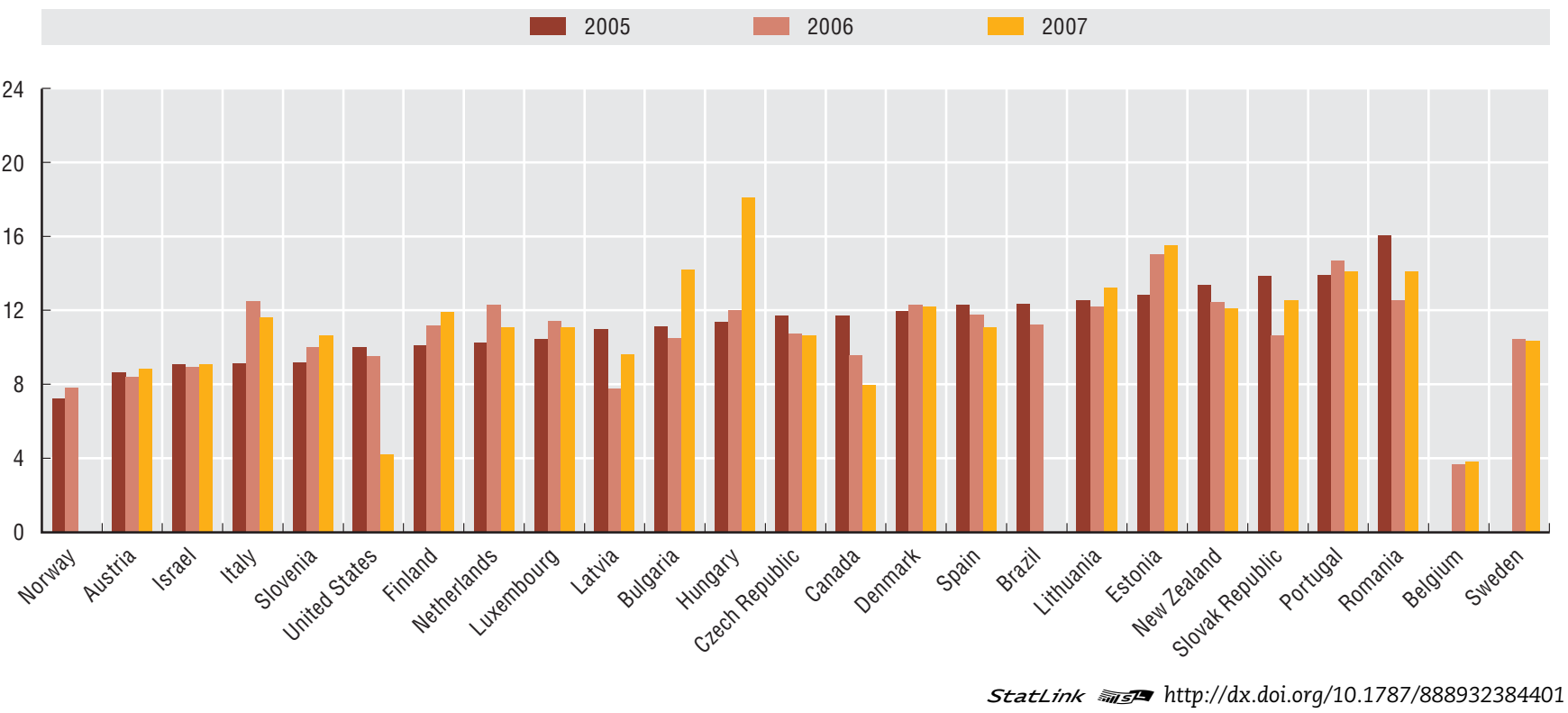

Figure 5.2. Employer enterprise birth rates in manufacturing and services in 2007

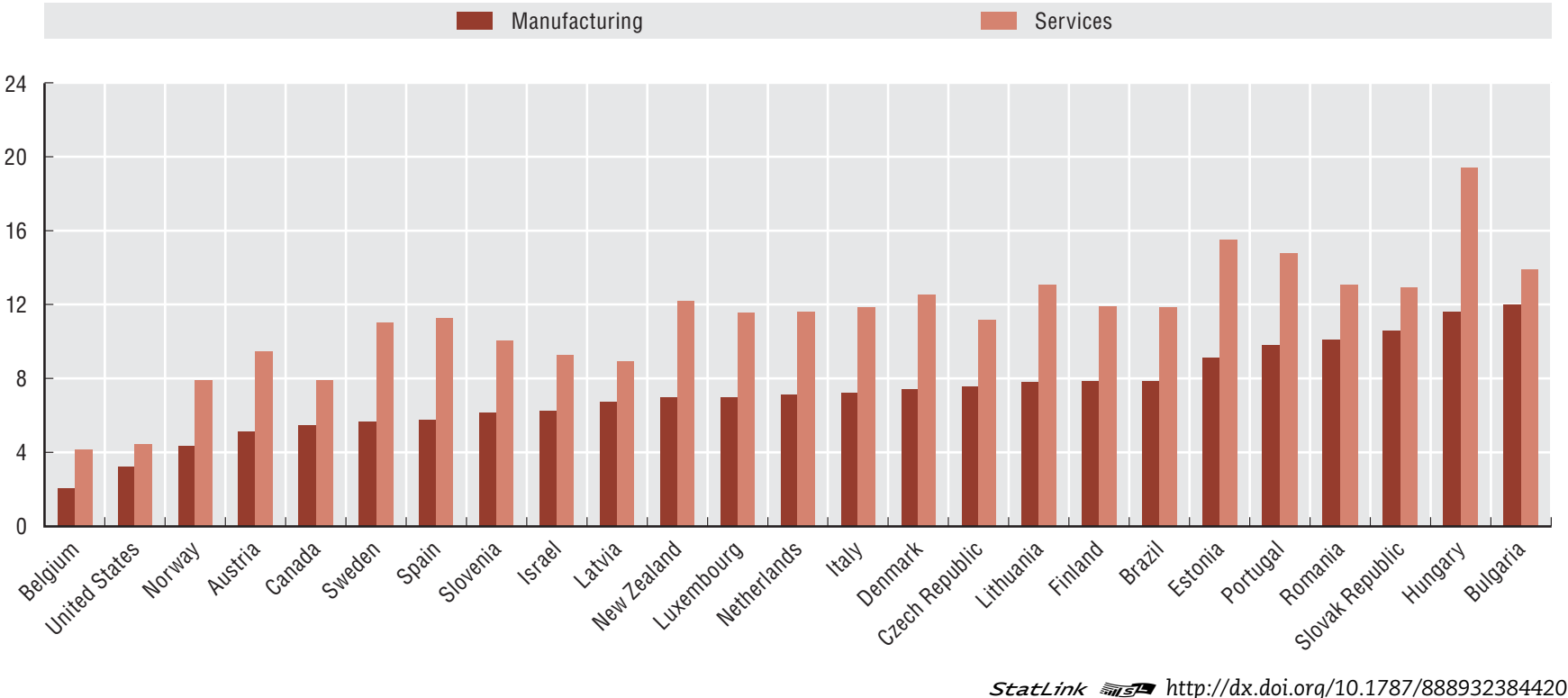




\section{ENTERPRISE BIRTH, DEATH AND SURVIVAL}

\section{Birth rate of employer enterprises}

Figure 5.3. Employer enterprise birth rate by size class in manufacturing in 2007

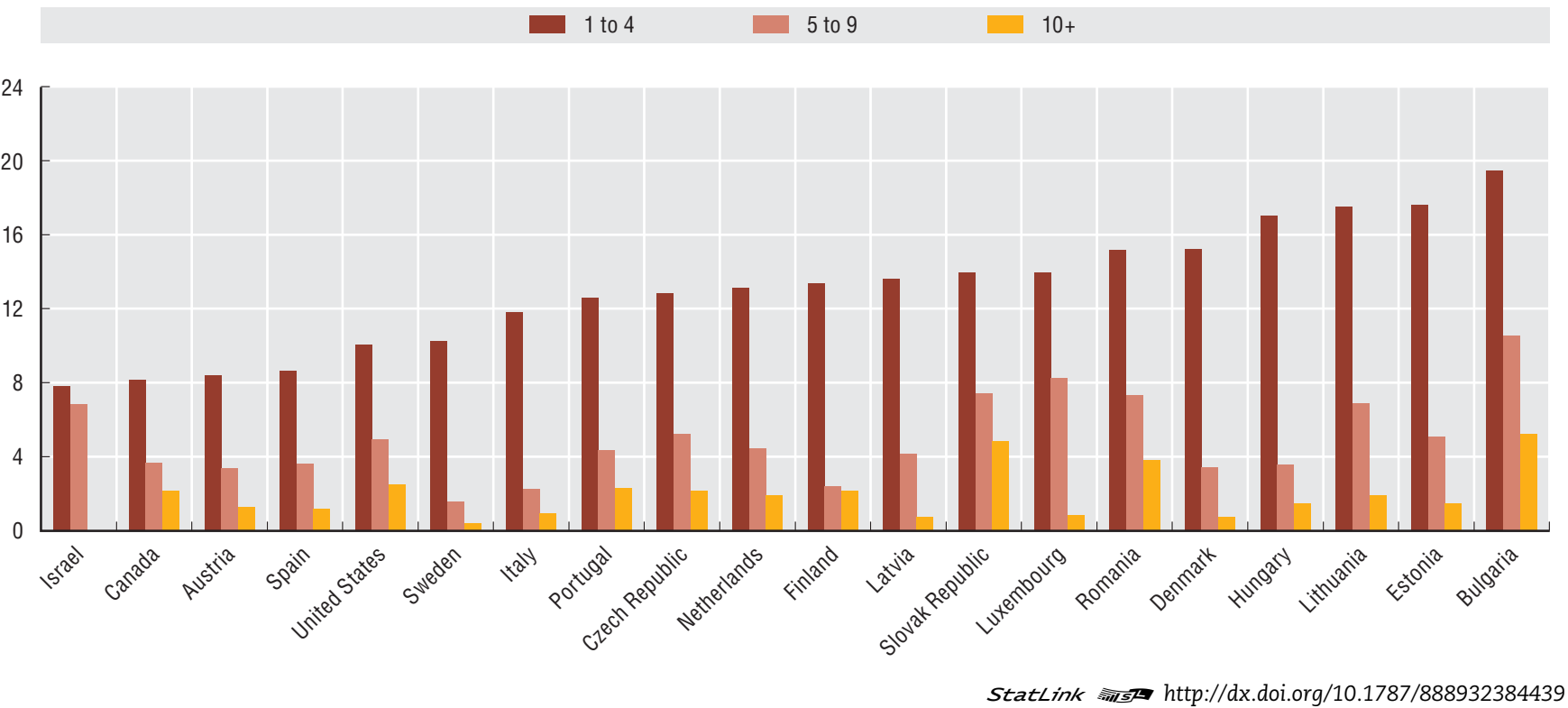

Figure 5.4. Employer enterprise birth rate by size class in services in 2007

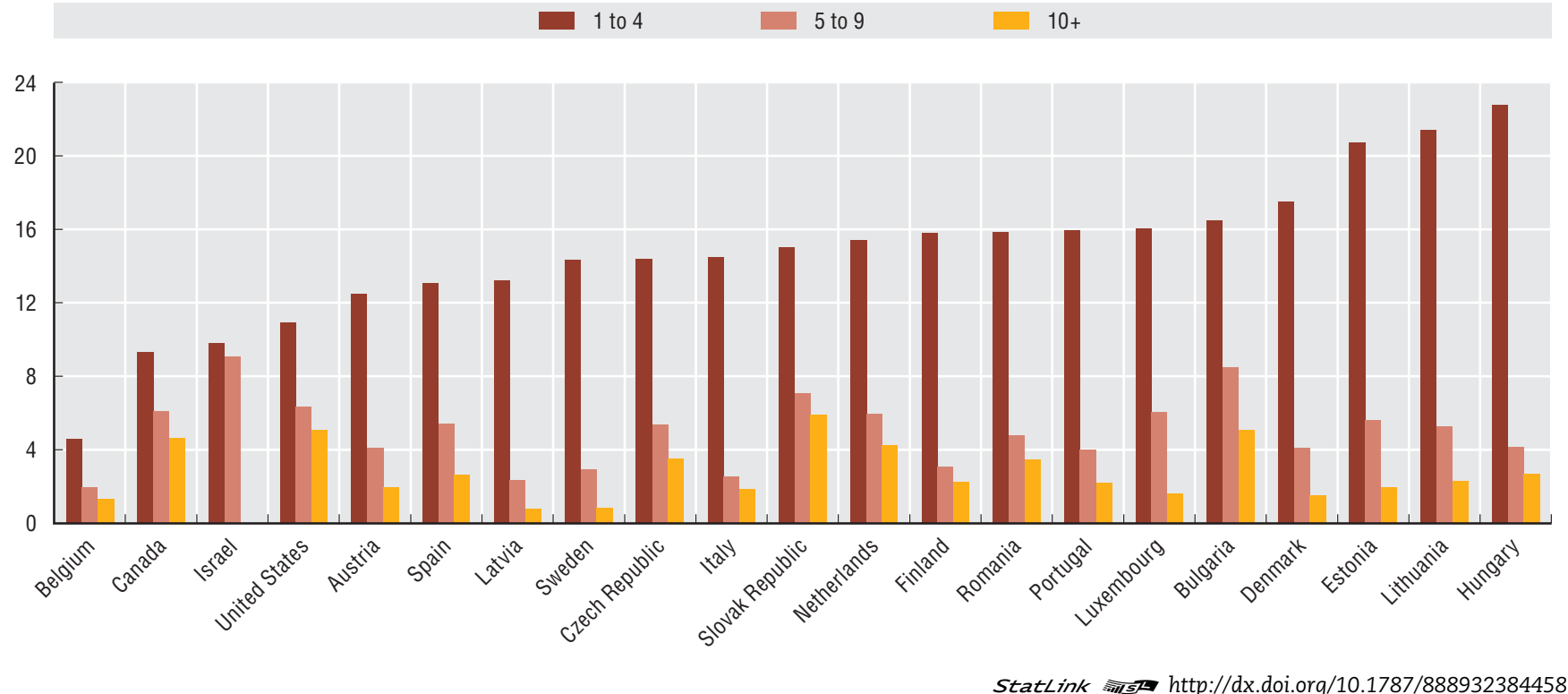




\section{ENTERPRISE BIRTH, DEATH AND SURVIVAL}

5. Birth rate of employer enterprises

Figure 5.5. Employer enterprise birth rates in various industries in $\mathbf{2 0 0 7}$

Food products, beverages and tobacco El_ Electrical and optical equipment $\quad$ Trade $\quad$ Other business services
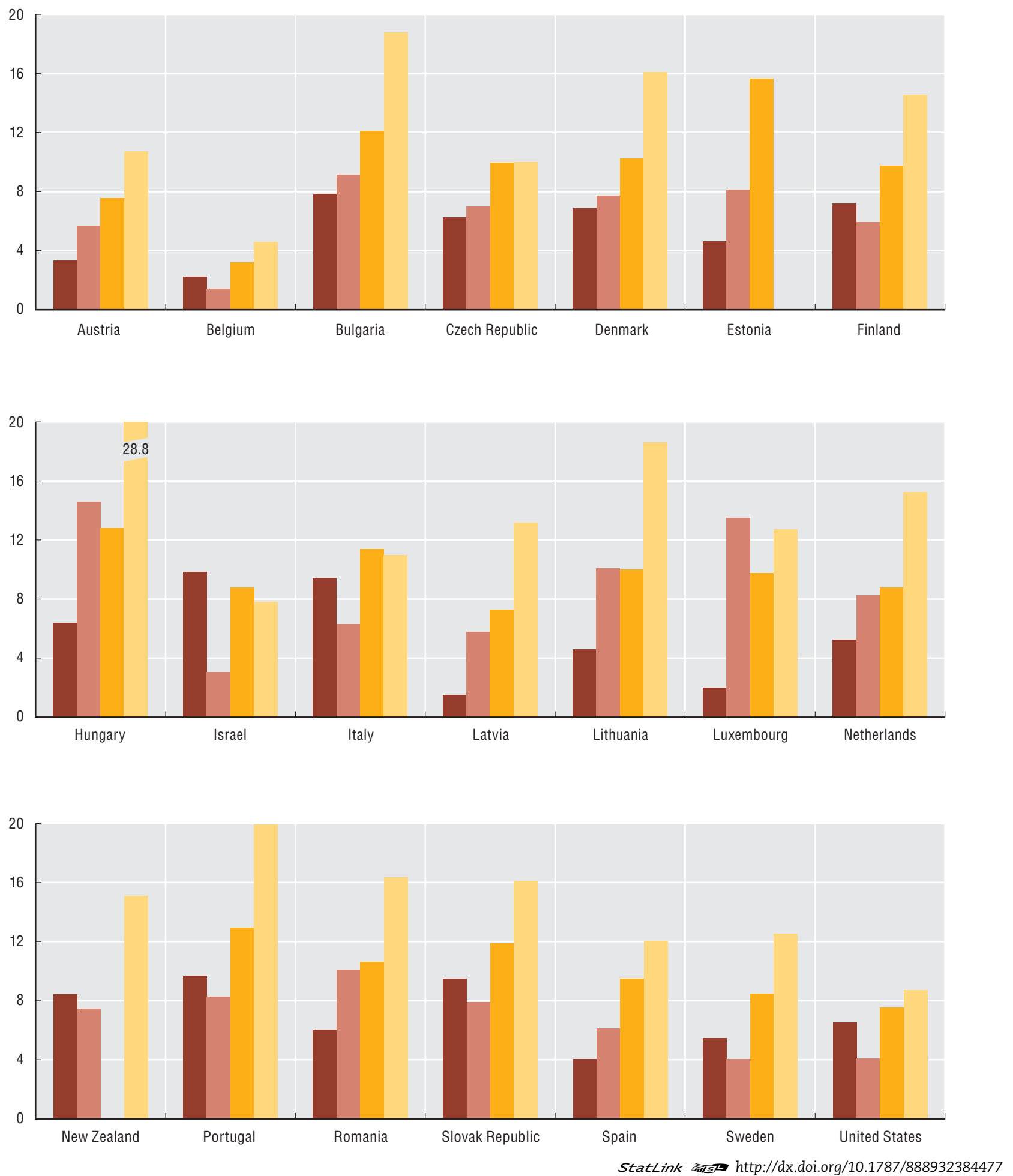


\section{Death rate of employer enterprises}

The death of enterprises is an integral part of the phenomenon of entrepreneurship. Knowing the percentage of firms that die in a given year and comparing it over time and across countries is of high interest to policy makers to understand, for example, the impact of structural and cyclical effects on the disappearance of enterprises.

\section{Definition}

An employer enterprise death occurs either as the death of an enterprise with at least one employee in the year of death or the move of an enterprise below the threshold of one employee for at least two years.

Deaths do not include exits from the population due to mergers, take-overs, break-ups and restructuring of a set of enterprises. They also exclude exits from a sub-population resulting only from a change of activity.

The employer enterprise death rate corresponds to the number of deaths of employer enterprises as a percentage of the population of active enterprises with at least one employee.

\section{Comparability}

Compared to data on births of employer enterprises, there is an additional time lag in data collection of enterprise deaths linked to the process of confirmation of the event: it has to be checked that the enterprise has not been reactivated (or had no employees) in the following two years. Hence, information on death rates presented in this publication refer mainly to 2006, and not to 2007 as for all other indicators.

"Employer" indicators are found to be more relevant for international comparisons than indicators covering all enterprises, as the latter are sensitive to the coverage of business registers. In many countries, the main sources of data used in business registers are administrative tax and employment registers, meaning that often only business above a certain turnover and/or employment threshold are captured. An additional complication in this regard relates to changes in thresholds over time. Monetary based thresh- olds change over time in response to e.g. inflation and fiscal policy, both of which can be expected to affect comparisons of death rates across countries and over time. The use of the one-employee thresholds improve comparability, as it excludes very small units, which are the most subject to threshold variations.

Data refer to the whole population of employer enterprises, with the exception of Canada, for which data refer to employer enterprises with less than 250 employees.

\section{Highlights}

In all countries, the death rates of employer enterprises in the services sector are consistently higher than the corresponding rates in the manufacturing sector. They are stable over time, although it is worthwhile to note that the data presented cover the precrisis period, namely 2005-2007. Very small firms, with 1 to 4 employees, have the highest death rates compared to firms in the other size classes.

\section{Source/Online database}

OECD Structural and Demographic Business Statistics (SDBS) Database.

http://dx.doi.org/10.1787/sdbs-data-en

\section{For further reading}

OECD (2010), "Structural and Demographic Business Statistics", Paris.

http://dx.doi.org/10.1787/9789264072886-en

Eurostat/OECD (2007), Eurostat-OECD Manual on Business Demography Statistics, OECD, Paris.

Ahmad, N. (2006), “A Proposed Framework For business Demography Statistics", OECD Statistics Working Papers, 2006/3, OECD Publishing, Paris.

http://dx.doi.org/10.1787/145777872685

Information on data for Israel:

http://dx.doi.org/10.1787/888932315602 
Figure 6.1. Employer enterprise death rates in all industries, 2005 to 2007

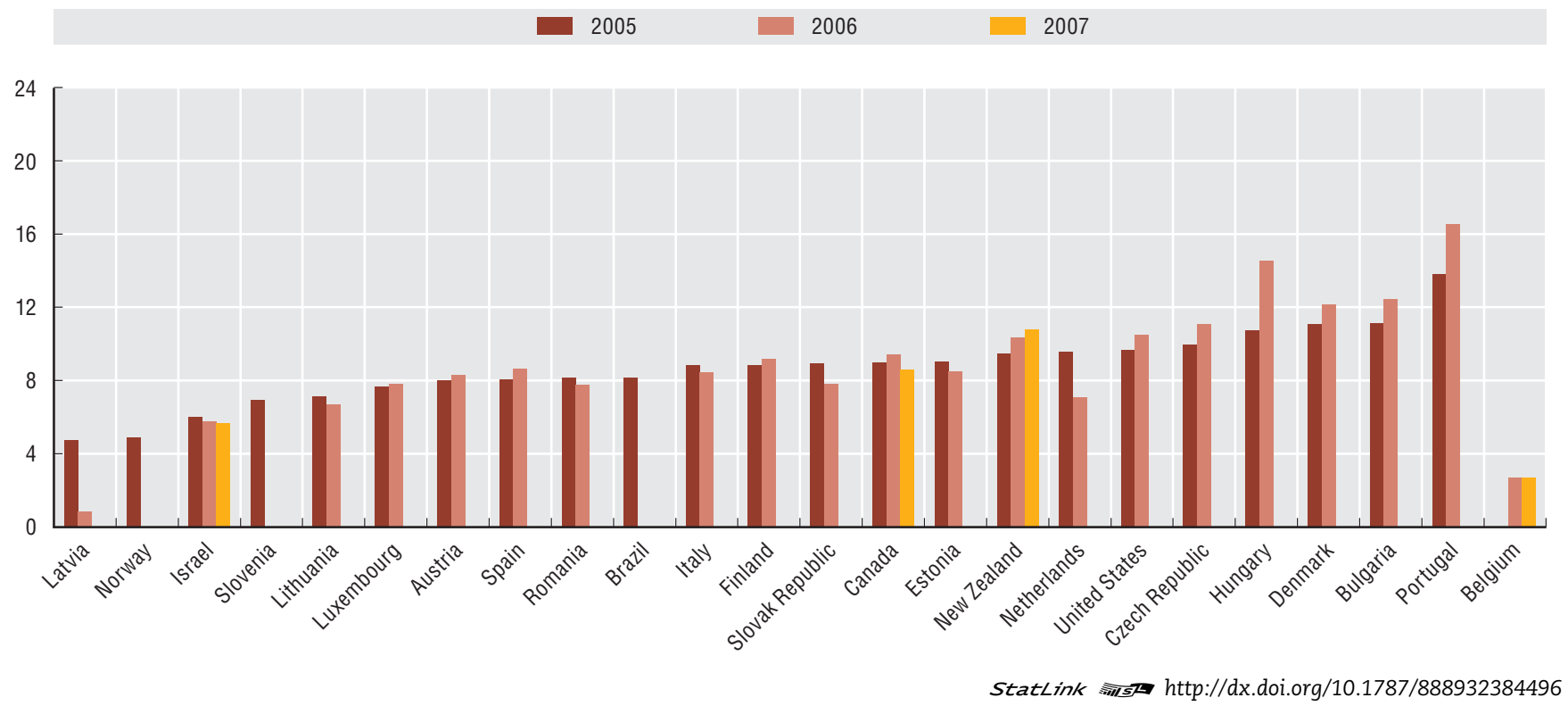

Figure 6.2. Employer enterprise death rates in manufacturing and services in 2006

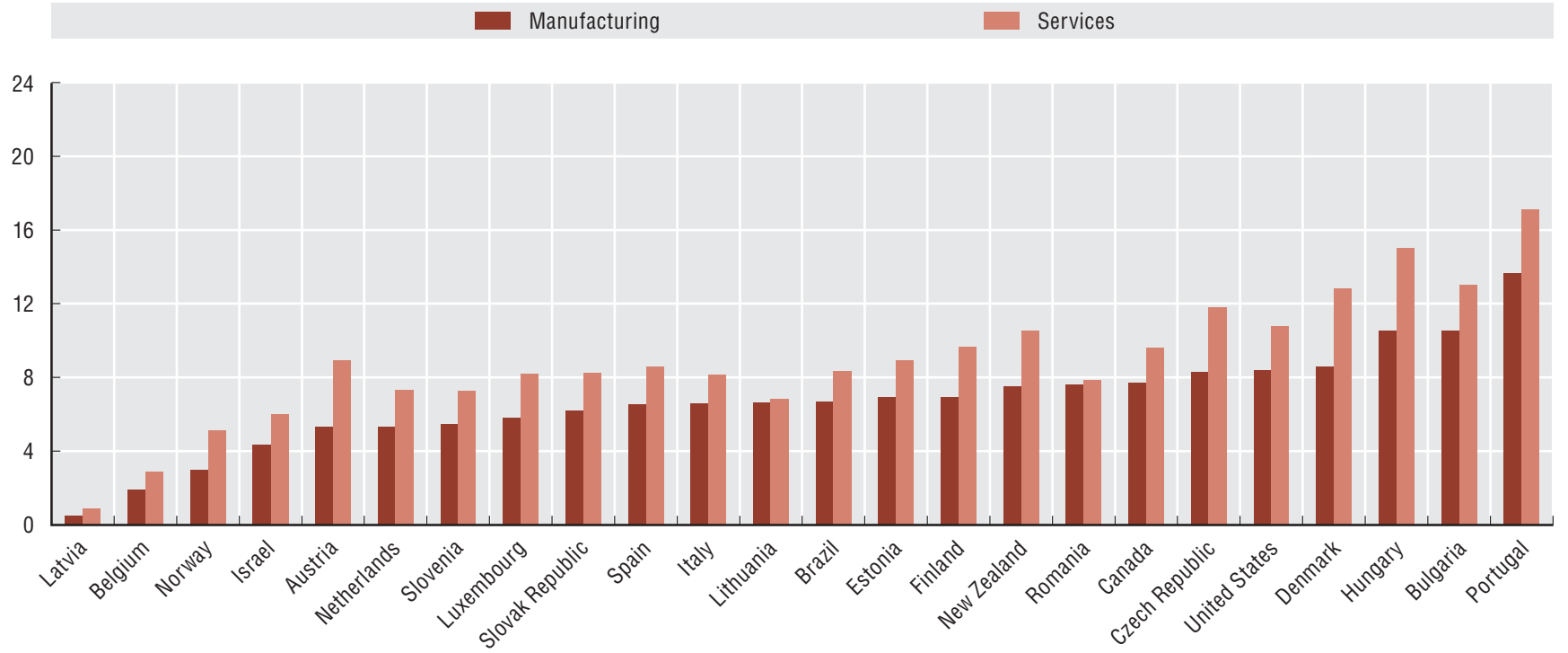

StatLink तiाs http://dx.doi.org/10.1787/888932384515 


\section{ENTERPRISE BIRTH, DEATH AND SURVIVAL}

\section{Death rate of employer enterprises}

Figure 6.3. Employer enterprise death rate in manufacturing by size class in 2006 (2007 in insert)

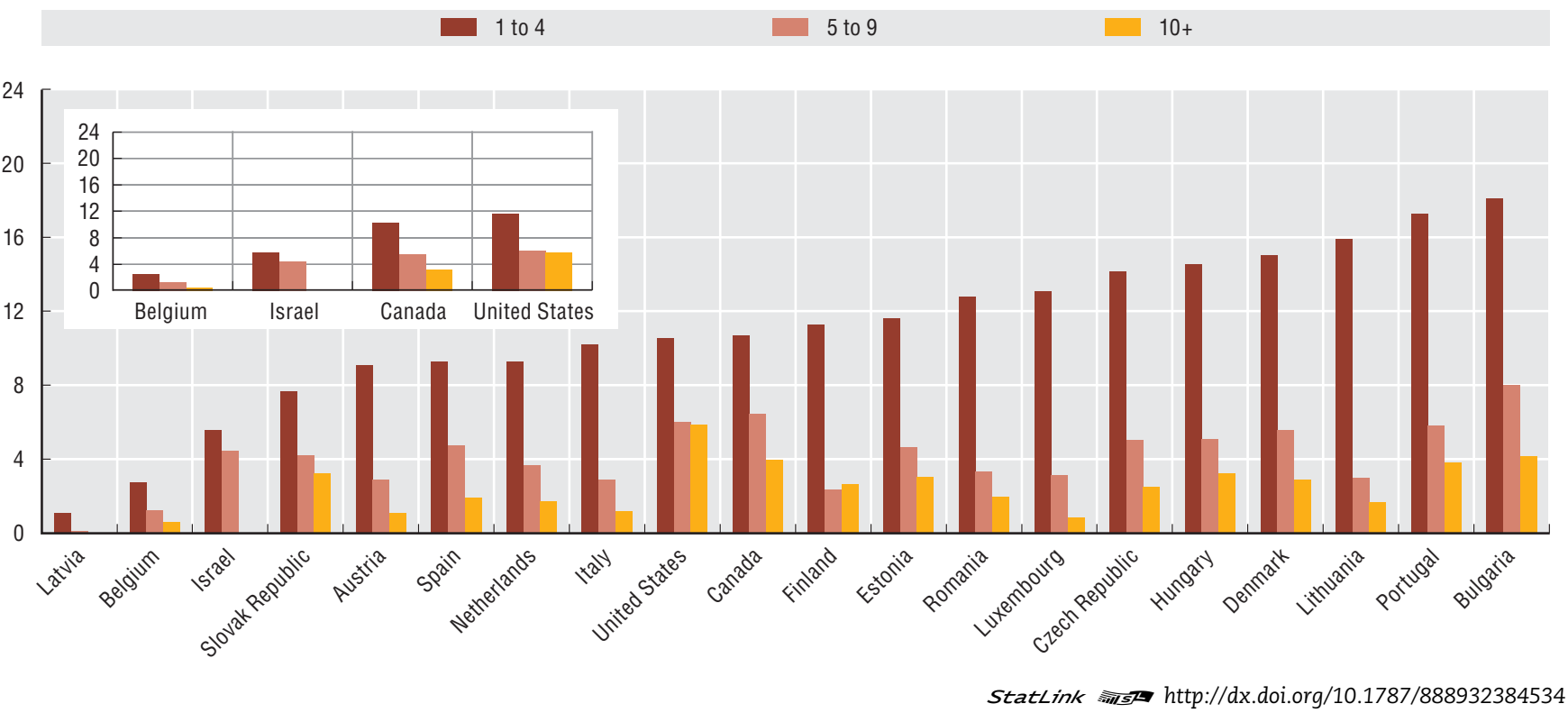

Figure 6.4. Employer enterprise death rate in services by size class in 2006 (2007 in insert)

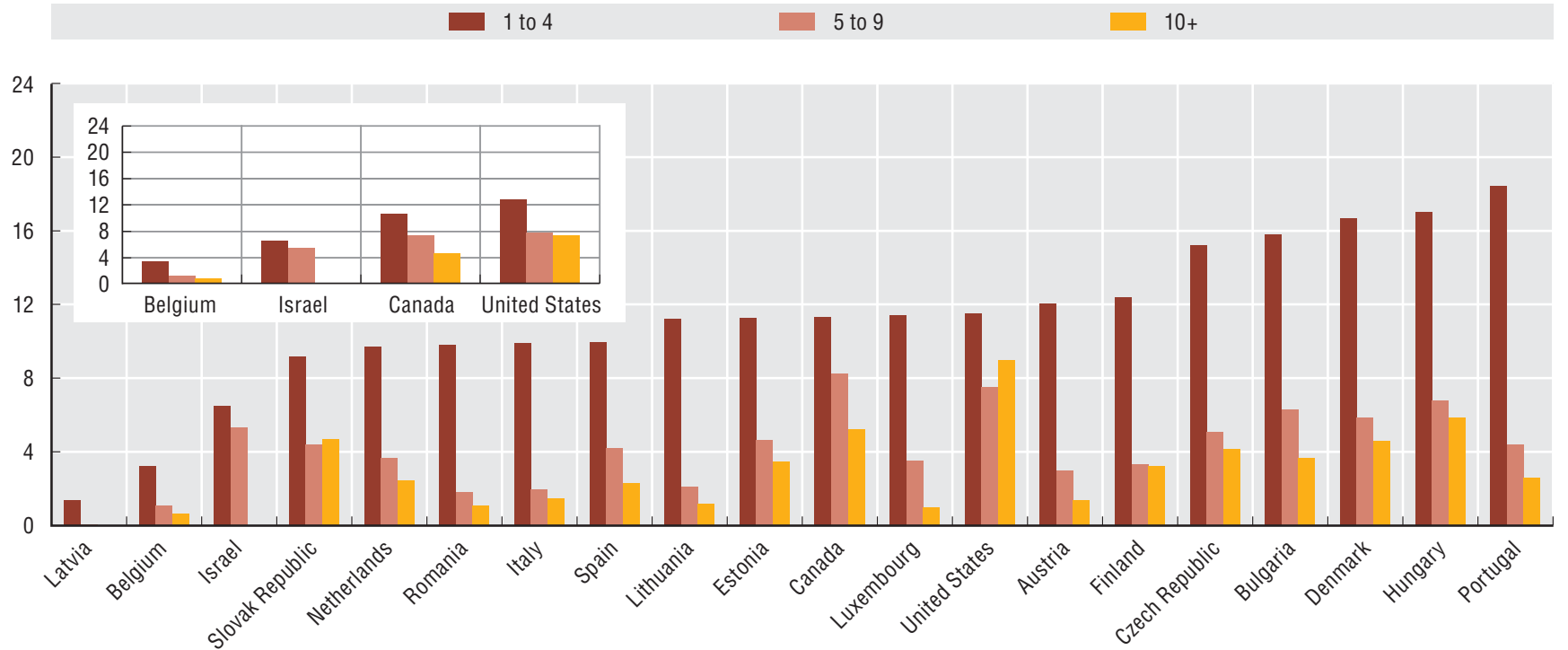

StatLink ल/1s http://dx.doi.org/10.1787/888932384553 
6. Death rate of employer enterprises

Figure 6.5. Employer enterprise death rates in various industries in 2006

Food products, beverages and tobacco Electrical and optical equipment $\quad$ El Trade
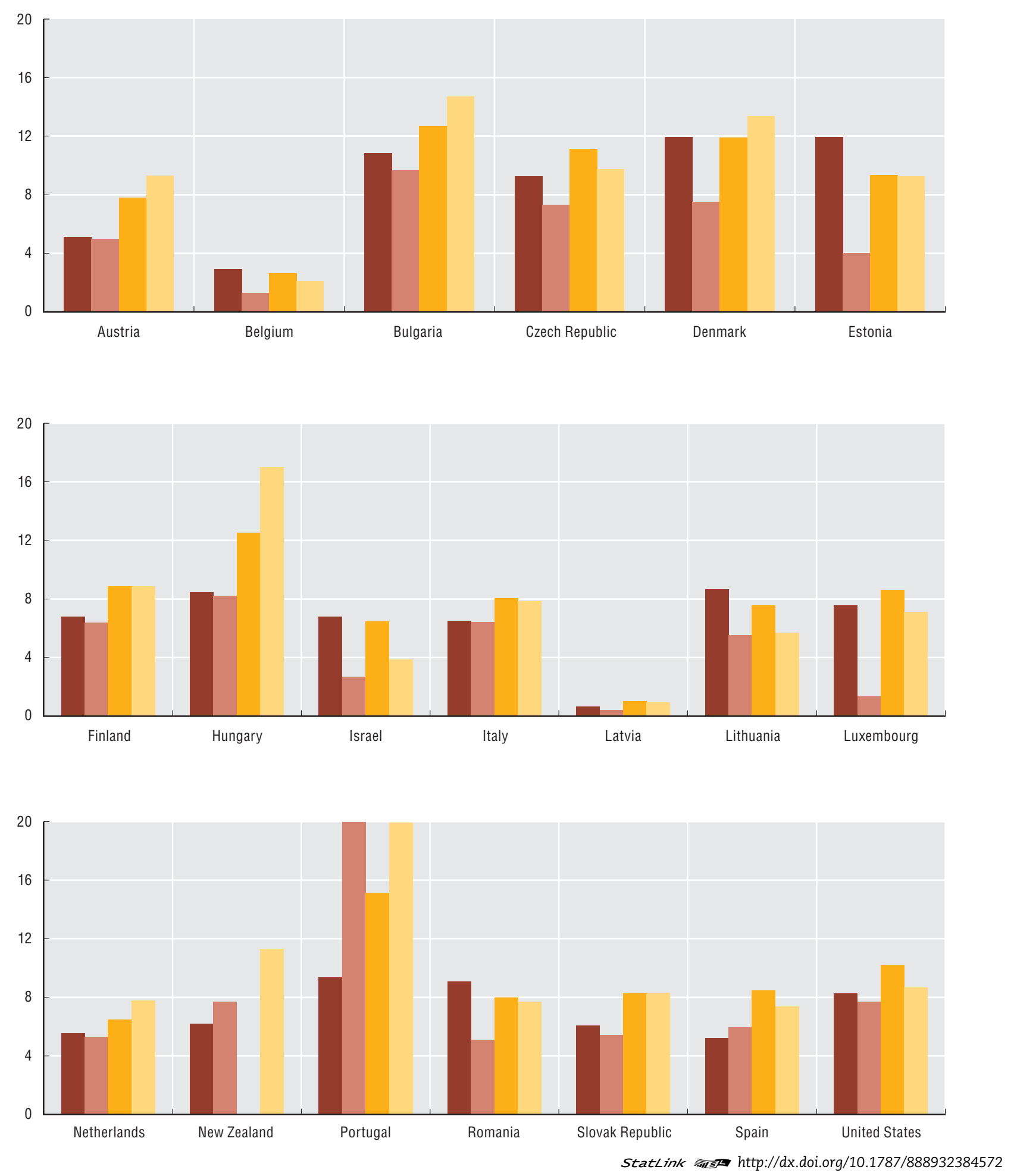


\section{Churn rate of employer enterprises}

The churn rate, i.e. the sum of births and deaths of enterprises, indicates how frequently new firms are created and how often existing enterprises close down. In fact, the number of births and deaths of enterprises accounts for a sizeable proportion of the total number of firms in most economies. The indicator reflects a country's degree of "creative destruction", and it is of high interest for analysing, for example, the contribution of firm churning to aggregate productivity growth.

\section{Definition}

The employer enterprise churn rate is compiled as the sum of the employer enterprise birth rate and the employer enterprise death rate.

The employer enterprise churn rate does not include entries and exits into the population due to mergers, break-ups or restructuring of a set of enterprises. It does not include exits due to take-overs. It does not include entries due to split-off. It does not include entries and exits into a sub-population resulting only from a change of activity.

There is a time lag in the employer enterprise churn rate compilation, linked to the process of confirmation of employer enterprise deaths, as it has to be checked that the enterprises considered as deaths have not been reactivated (or had no employees) in the following two years. Therefore, the most recent data on the churn rate presented refer to 2006.

\section{Comparability}

Employer enterprise birth and death data used in the compilation of the employer enterprise churn rate follow the definition from the Eurostat-OECD Manual on Business Demography Statistics.

As developed in the previous sections, "employer" indicators are found to be more relevant for international comparisons than indicators covering all enterprises, as the latter are sensitive to the coverage of business registers.
Data refer to the whole population of employer enterprises, with the exception of Canada, for which data refer to employer enterprises with less than 250 employees.

\section{Highlights}

Churn rates of employer enterprises are higher in the services sector than in manufacturing, reflecting a more significant business dynamics in services. Churn rates are relatively similar across countries, ranging from 12 to $16 \%$ in manufacturing and from 18 to $22 \%$ in services. Only a few countries show much lower (i.e. Belgium) or much higher (for example, Portugal) churn rates.

\section{Source/Online database}

OECD Structural and Demographic Business Statistics (SDBS) Database.

http://dx.doi.org/10.1787/sdbs-data-en

\section{For further reading}

OECD (2010), Structural and Demographic Business Statistics, OECD Publishing, Paris.

http://dx.doi.org/10.1787/9789264072886-en

Eurostat/OECD (2007), Eurostat-OECD Manual on Business Demography Statistics, OECD, Paris.

Ahmad, N. (2006), “A Proposed Framework For business Demography Statistics", OECD Statistics Working Papers, 2006/3, OECD Publishing, Paris. http://dx.doi.org/10.1787/145777872685

Scarpetta, S. et al. (2002), "The role of policy and institutions for productivity and firm dynamics: evidence from micro and industry data", OECD Economic Department Working Papers, No. 329.

http://dx.doi.org/10.1787/547061627926

Information on data for Israel:

http://dx.doi.org/10.1787/888932315602 
Figure 7.1. Employer enterprise churn rate in 2006 and 2005 in manufacturing

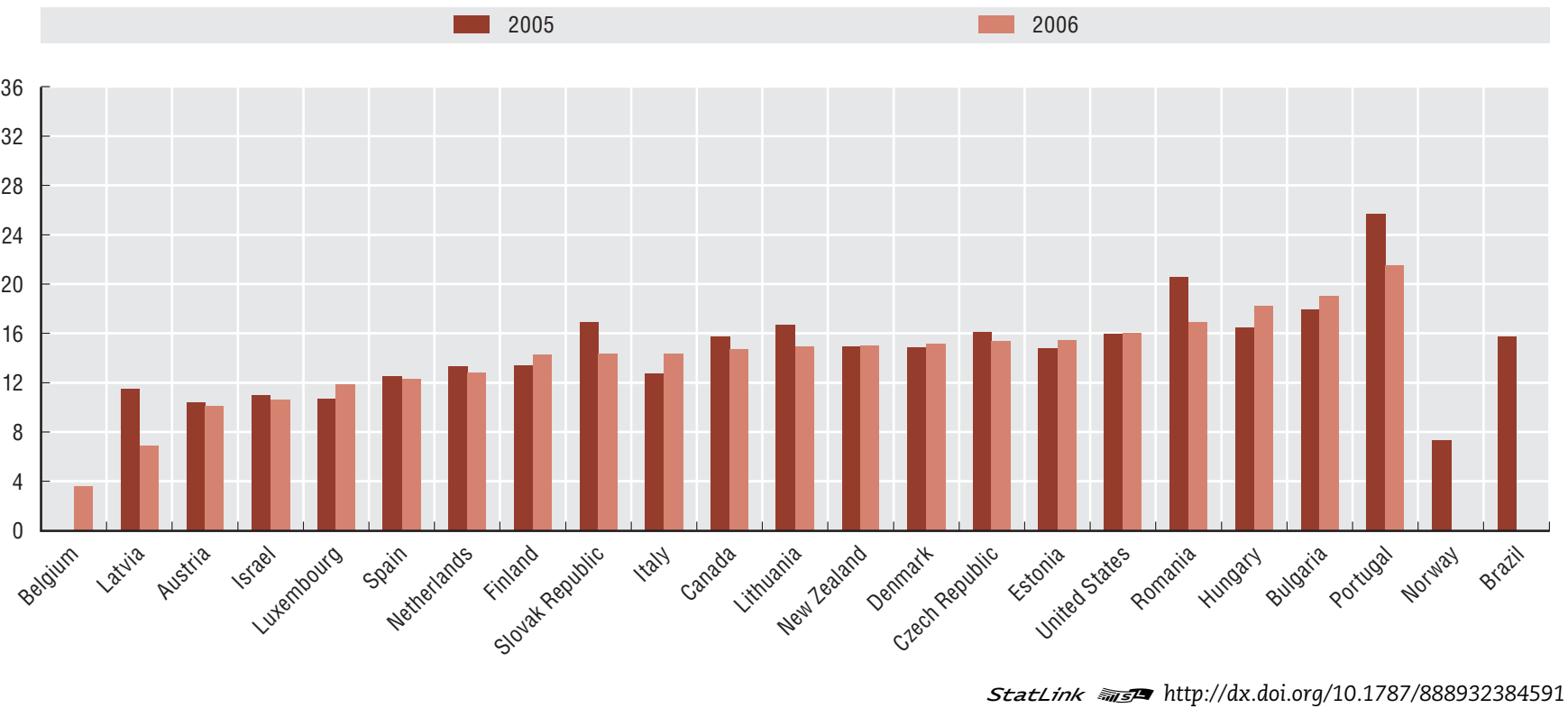

Figure 7.2. Employer enterprise churn rate in 2006 and 2005 in services

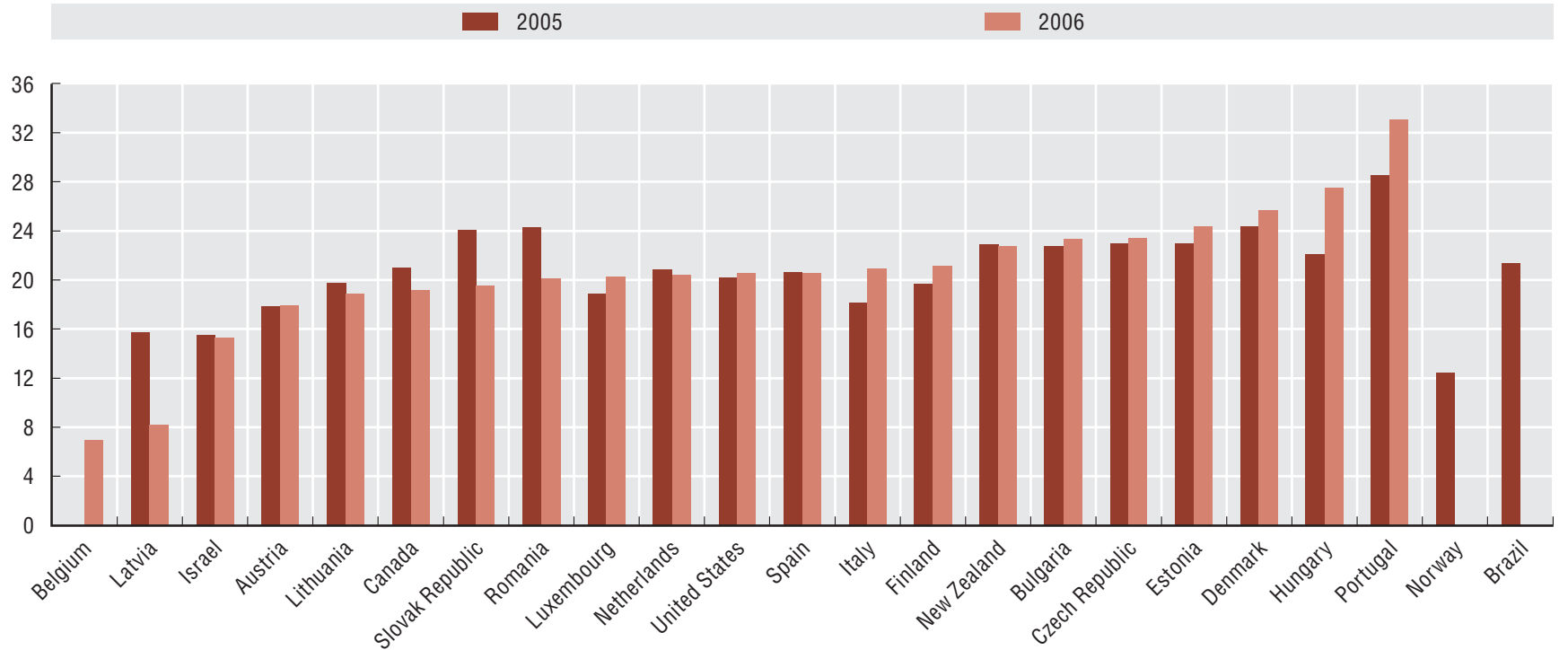

StatLink काजय http://dx.doi.org/10.1787/888932384610 


\section{Survival rate of employer enterprises}

Observing the post-entry performance of firms is as important as analysing their birth rate. The survival rate of enterprises provides information on the share of enterprises surviving one or more years after birth, and allows to investigate questions such as how long do start-ups survive after creation and the differences in survival rates of enterprises across countries and industries.

\section{Definitions}

The number of n-year survival enterprises for a particular year $t$ refers to the number of enterprises which had at least one employee for the first time in year $t-n$ and have not died in year $t$.

An enterprise is also considered to have survived if the linked legal unit(s) has (have) ceased to be active, but their activity has been taken over by a new legal unit set up specifically to take over the factors of production of that enterprise (survival by takeover). This definition of survival excludes cases in which enterprises merge or are taken over by an existing enterprise in year $\mathrm{t}-\mathrm{n}$.

The survival of an enterprise is an event that should always be observed between two consecutive years. For instance, an enterprise born in year t-2 should be considered as having survived to $t$ only if it had at least one employee also in year $\mathrm{t}-1$, and so forth.

The employer enterprise survival rate measures the number of enterprises of a specific birth cohort that have survived over different years. The n-year survival rate for a reference year $t$ is calculated as the number of $\mathrm{n}$-year survival enterprises as a percentage of all enterprises that reported at least one employee for the first time in year $t-n$.

The share of $n$-year-old employer enterprises for a particular year $t$ refers to the number of n-year survival enterprises as a percentage of the total employer enterprise population in year $t$.

\section{Comparability}

Employer enterprise survival data in this publication follow the definition from the Eurostat-OECD Manual on Business Demography Statistics.

Data refer to the whole population of employer enterprises, with the exception of Canada, for which data refer to employer enterprises with less than 250 employees.

\section{Highlights}

The survival rates of employer enterprises in the manufacturing sector are typically higher than in the services sector and the difference persists in every year after birth; Canada is an exception, with the survival rates almost identical across the two sectors. On average, the survival rates after one year are around 85 to $90 \%$ in manufacturing and 75 to $80 \%$ in services, and they continue to drop constantly in the following years.

\section{Source/Online database}

OECD Structural and Demographic Business Statistics (SDBS) Database.

http://dx.doi.org/10.1787/sdbs-data-en

\section{For further reading}

OECD (2010), Structural and Demographic Business Statistics, OECD Publishing, Paris.

http://dx.doi.org/10.1787/9789264072886-en

Eurostat/OECD (2007), Eurostat-OECD Manual on Business Demography Statistics, OECD, Paris.

Ahmad, N. (2006), “A Proposed Framework For business Demography Statistics", OECD Statistics Working Papers, 2006/3, OECD Publishing, Paris.

http://dx.doi.org/10.1787/145777872685

Information on data for Israel:

http://dx.doi.org/10.1787/888932315602 
Figure 8.1. Enterprise survival rates in manufacturing and services
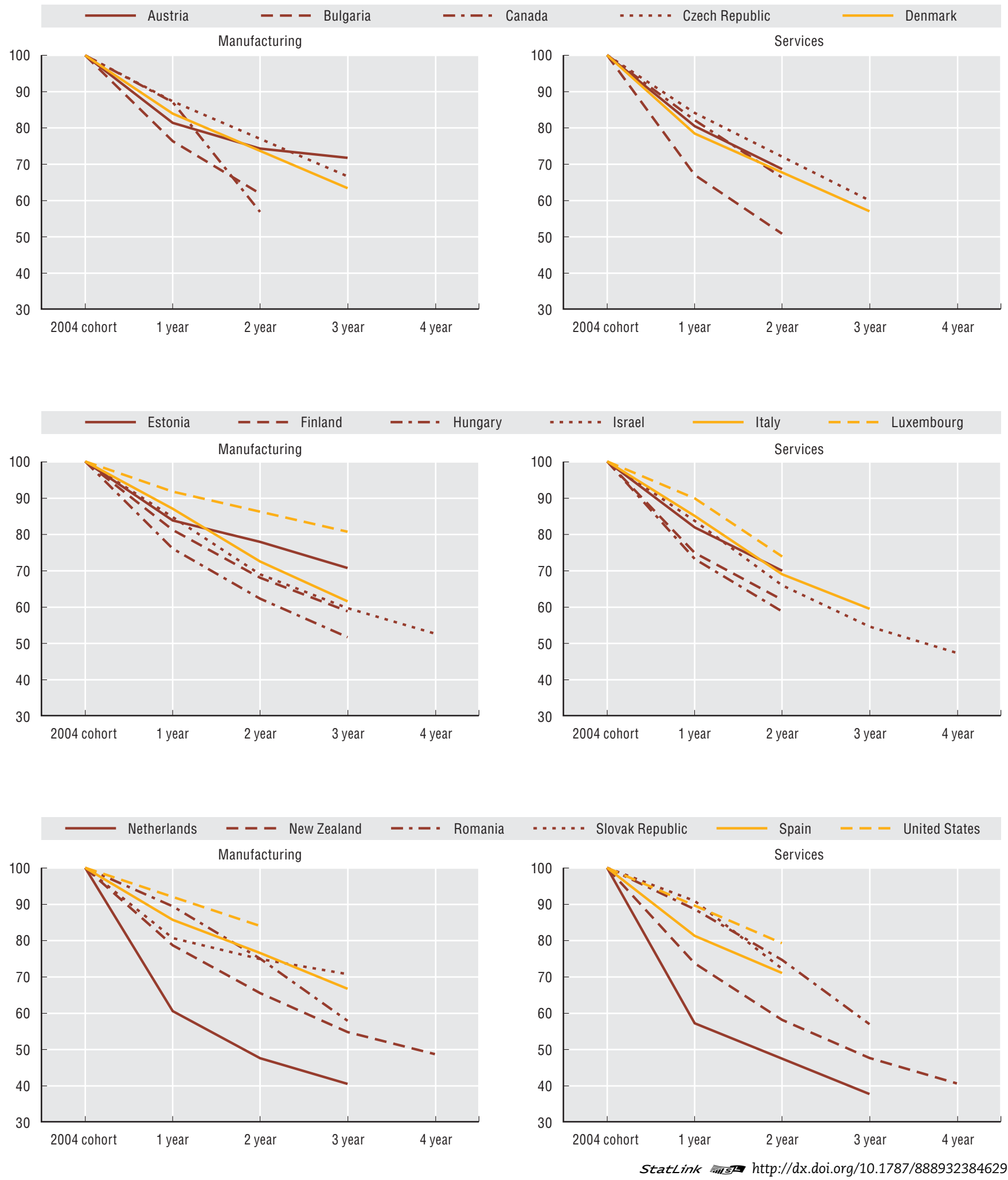


\section{ENTERPRISE BIRTH, DEATH AND SURVIVAL}

\section{Survival rate of employer enterprises}

Figure 8.2. Share of enterprises by age group in manufacturing in 2007

1 year old enterprises' share of the business population

3 year old enterprises' share of the business population

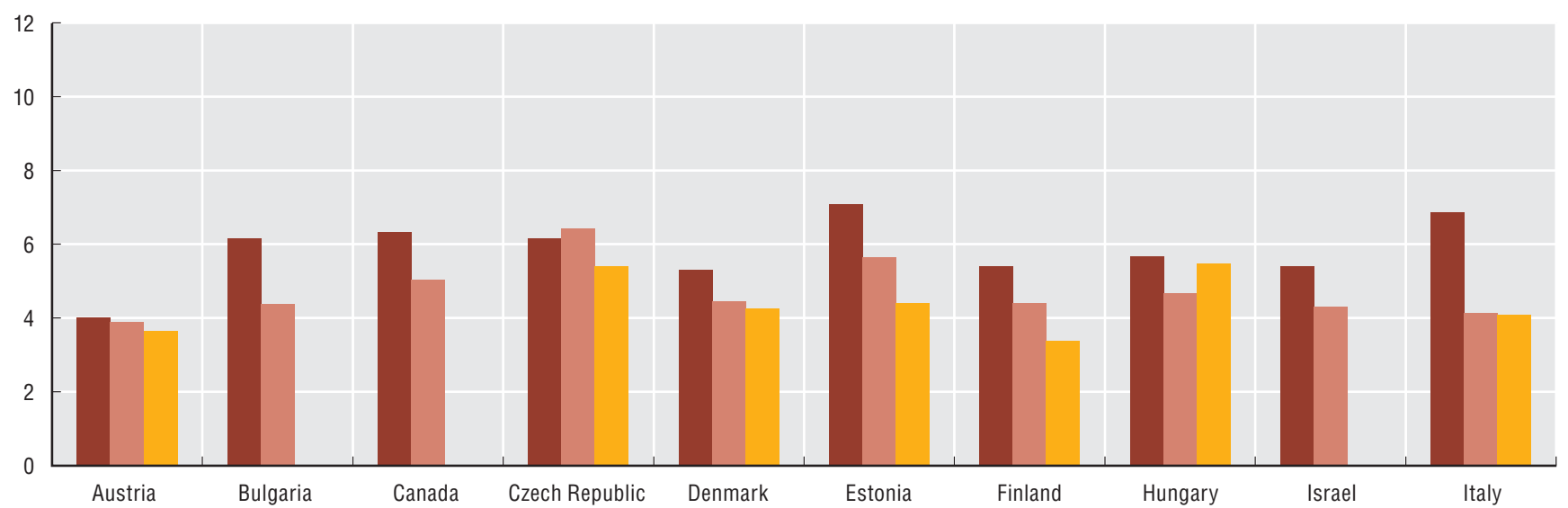




\section{ENTERPRISE BIRTH, DEATH AND SURVIVAL}

\section{Survival rate of employer enterprises}

Figure 8.3. Share of enterprises by age group in services in 2007

1 year old enterprises' share of the business population

3 year old enterprises' share of the business population

2 year old enterprises' share of the business population
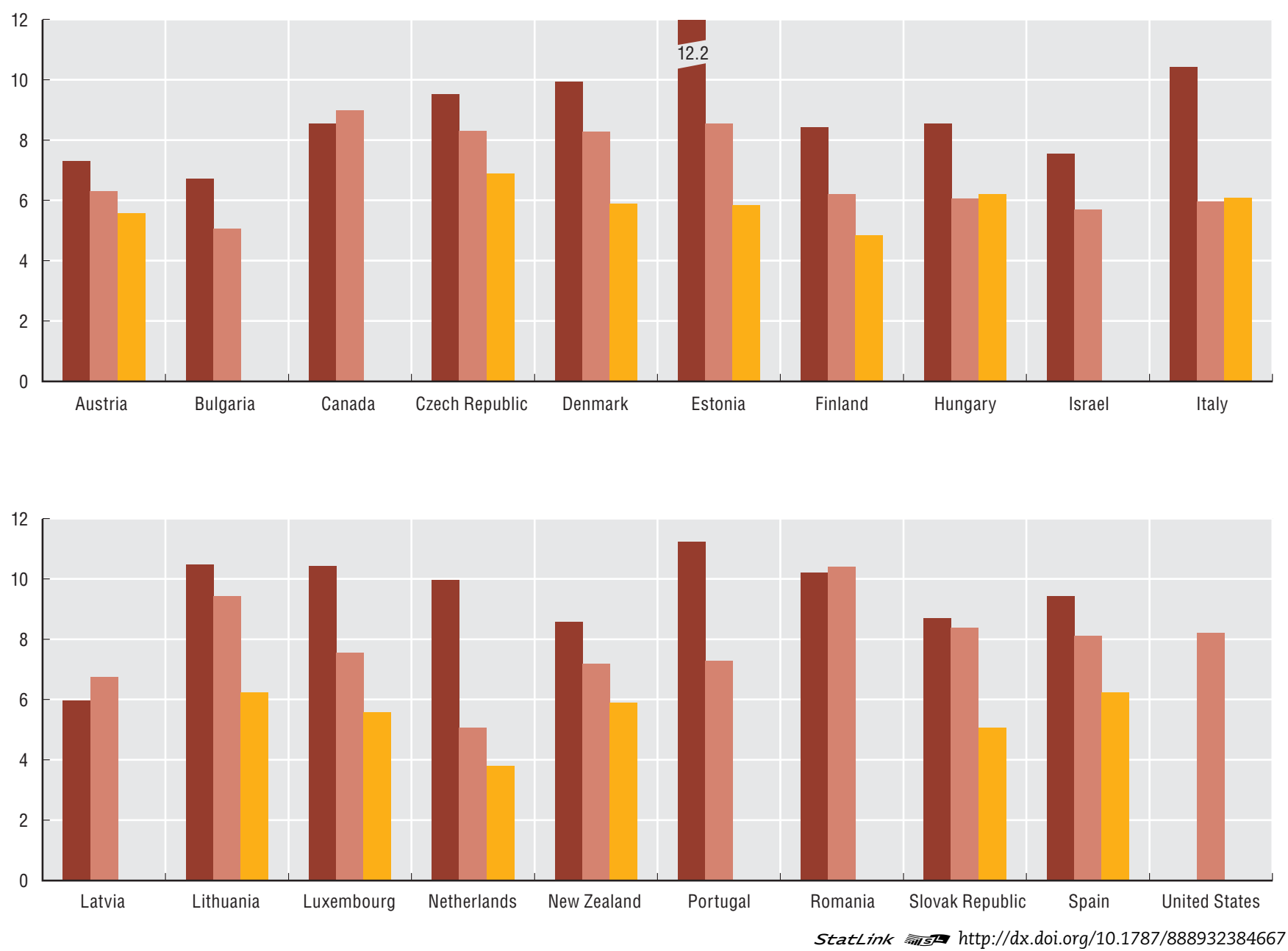

EMPLOYMENT CREATION AND DESTRUCTION

9. Employment creation and destruction by employer enterprise births and deaths

10. Employment creation and destruction in surviving enterprises

ENTREPRENEURSHIP AT A GLANCE 2011 ๑ OECD 2011

67 
The observation of the employment created by firm births or destructed by firm deaths provides an indication of how enterprise business demography contributes to overall employment changes in the economy.

\section{Definitions}

The employment creation by births is measured as the employment share of employer enterprise births. It is calculated as the number of persons employed in the reference period $t$ in employer enterprises newly born in $t$ divided by the number of persons employed in $t$ in the stock of employer enterprises.

Symetrically, the employment destruction by deaths is measured as the employment share of employer enterprise deaths. It is calculated as the number of persons employed in the reference period $t$ in exiting employer enterprises divided by the number of persons employed in $t$ in the stock of employer enterprises.

While there exists much evidence in support of, alternatively, the dominance of small or larger firms in net employment growth, research in the United States brought to the attention the fact that the age of enterprises could be more relevant than their size in determining their contribution to employment growth. In particular, young enterprises seem to be responsible for a large proportion of employment churning, i.e. creation and destruction of jobs in the economy, because they are more volatile: start-ups have higher probabilities of exiting the market in their first years of life.

\section{Comparability}

Data refer to the whole population of employer enterprises.

\section{Highlights}

There are important differences across countries in the extent to which the birth and death of employer enterprises affect, respectively, the creation and destruction of jobs in the economy. In all countries, however, the level of employment churning is quite stable over the years, and constantly higher in services than in the manufacturing sector.

\section{Source/Online database}

OECD Structural and Demographic Business Statistics (SDBS) Database.

http://dx.doi.org/10.1787/sdbs-data-en

\section{For further reading}

Haltiwanger, J., R.S. Jarmin and J. Miranda (2010), "Wo create jobs? Small us. Large us. Young”, Discussion Papers, US Census Bureau.

Eurostat/OECD (2007), Eurostat-OECD Manual on Business Demography Statistics, OECD, Paris.

Ahmad, N. (2006), “A Proposed Framework For business Demography Statistics", OECD Statistics Working Papers, 2006/3, OECD Publishing, Paris. http://dx.doi.org/10.1787/145777872685

Information on data for Israel:

http://dx.doi.org/10.1787/888932315602 
Figure 9.1. Employment share of employer enterprise births in manufacturing and services in 2007

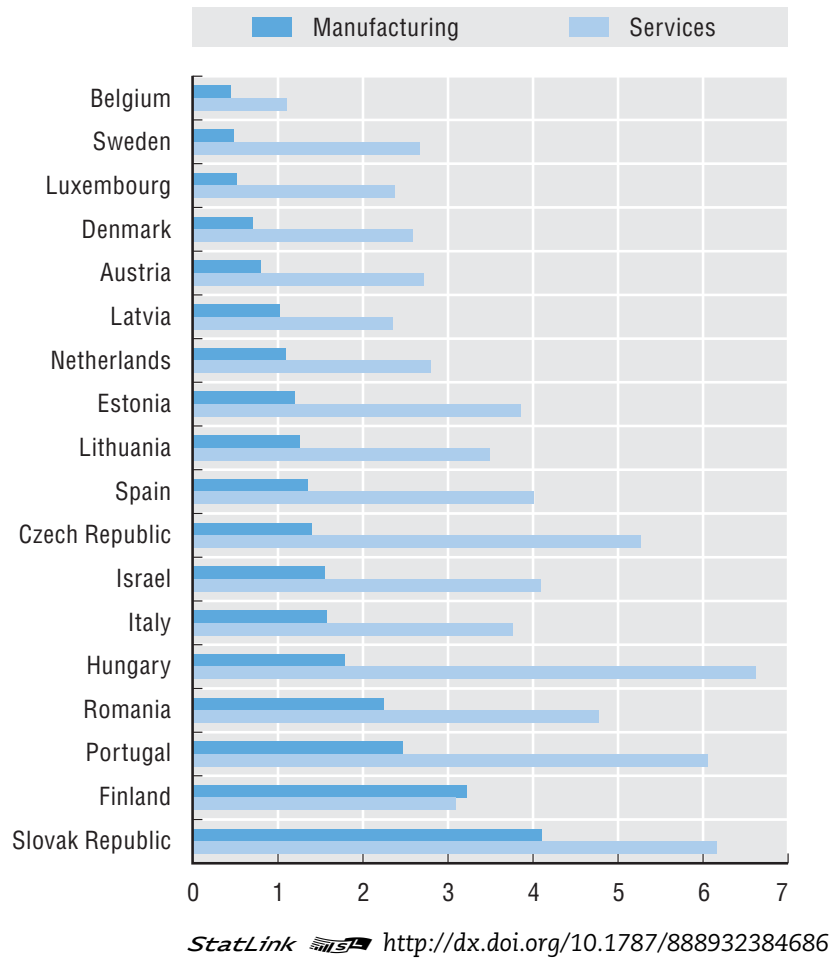

Figure 9.3. Employment share of employer enterprise births in total economy

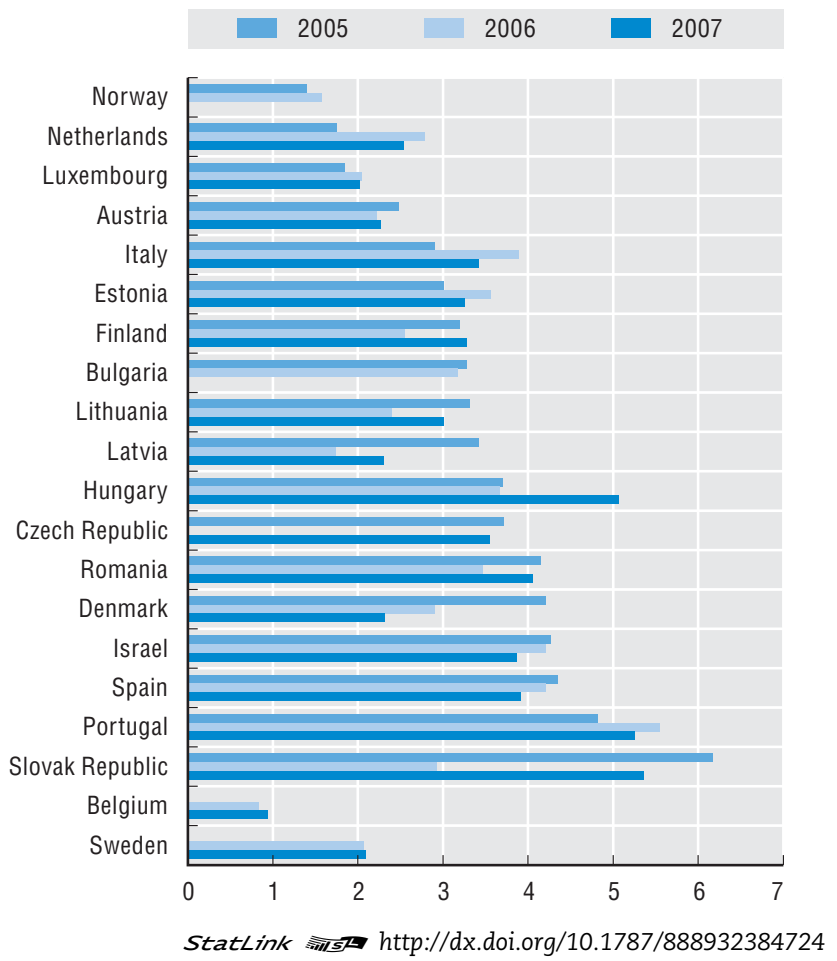

Figure 9.2. Employment share of employer enterprise deaths in manufacturing and services in 2007

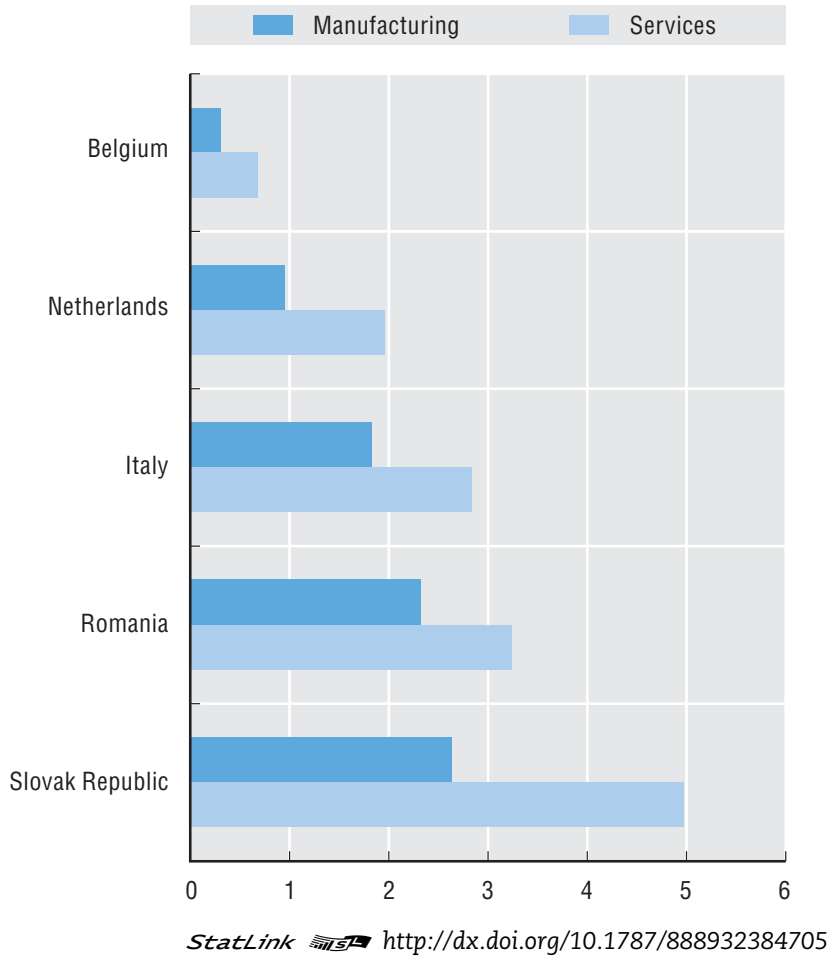

Figure 9.4. Employment share of employer enterprise deaths in total economy

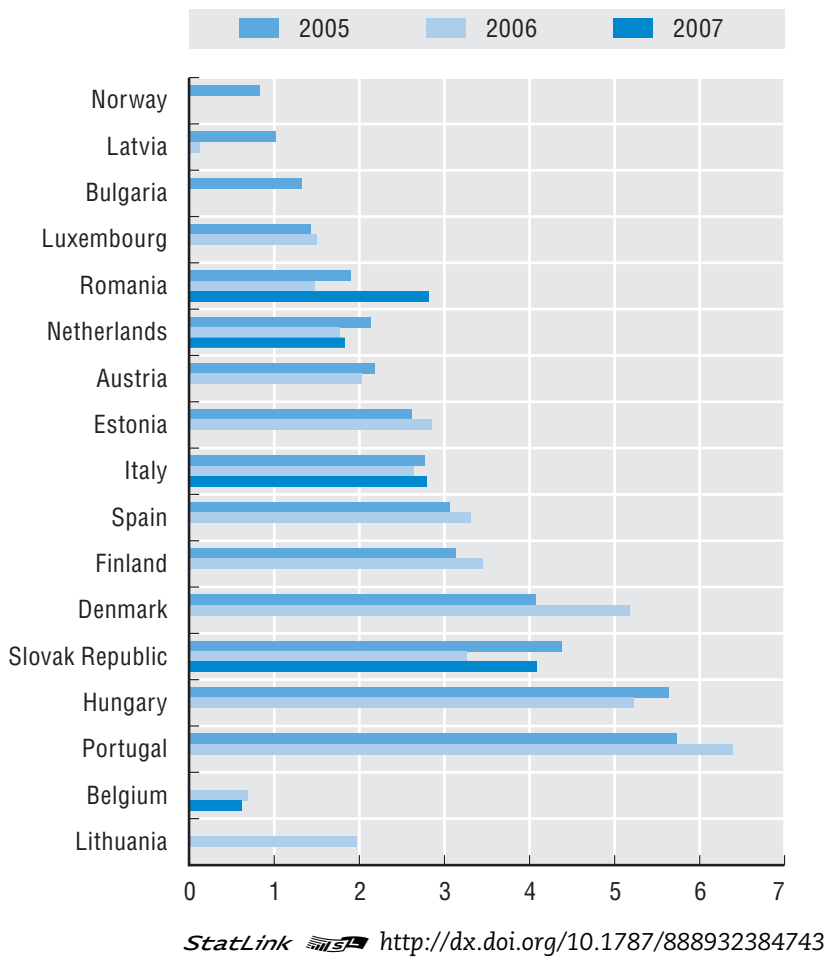




\section{EMPLOYMENT CREATION AND DESTRUCTION}

\section{Bmployment creation and destruction in surviving enterprises}

The comparison of the employment share of one-year old (respectively two-year old) enterprises in their year of birth with their employment share after one year (respectively two years) of existence, provides an indication of how rapidly the young surviving enterprises are increasing their number of persons employed beyond the intial level and contribute to overall employment changes in the economy.

\section{Definitions}

The employment share at birth of one-year old (respectively two-year old) employer enterprises refers to the number of persons employed in the year of birth by employer enterprises that will have survived 1 year (respectively two years), divided by the total number of persons employed.

The employment share of 1-year old (respectively two-year old) employer enterprises refers to the number of persons employed in one-year old employer enterprises, divided by the total number of persons employed.

\section{Comparability}

Data refer to the whole population of employer enterprises.

\section{Highlights}

On average, the employment share of one-year old enterprises in 2007 have shown an increased of $40 \%$ compared to their year of birth. The increase in the employment share of 2-year old enterprises compared to their year of birth (about 55\%) is of course higher, but these figures would tend to indicate that the first survival year is more deteminant than the second survival year for the employment growth.

\section{Source/Online database}

OECD Structural and Demographic Business Statistics (SDBS) Database.

http://dx.doi.org/10.1787/sdbs-data-en

\section{For further reading}

Haltiwanger, J., R.S. Jarmin and J. Miranda (2010), "Wo create jobs? Small us. Large us. Young”, Discussion Papers, US Census Bureau.

Eurostat/OECD (2007), Eurostat-OECD Manual on Business Demography Statistics, OECD, Paris.

Ahmad, N. (2006), “A Proposed Framework For business Demography Statistics", OECD Statistics Working Papers, 2006/3, OECD Publishing, Paris.

http://dx.doi.org/10.1787/145777872685 


\section{EMPLOYMENT CREATION AND DESTRUCTION}

Figure 10.1. Employment in year of birth and in the 1st survival year in all industries, enterprises that have survived 1 year in 2007, as a percentage of employment in the population of active enterprises

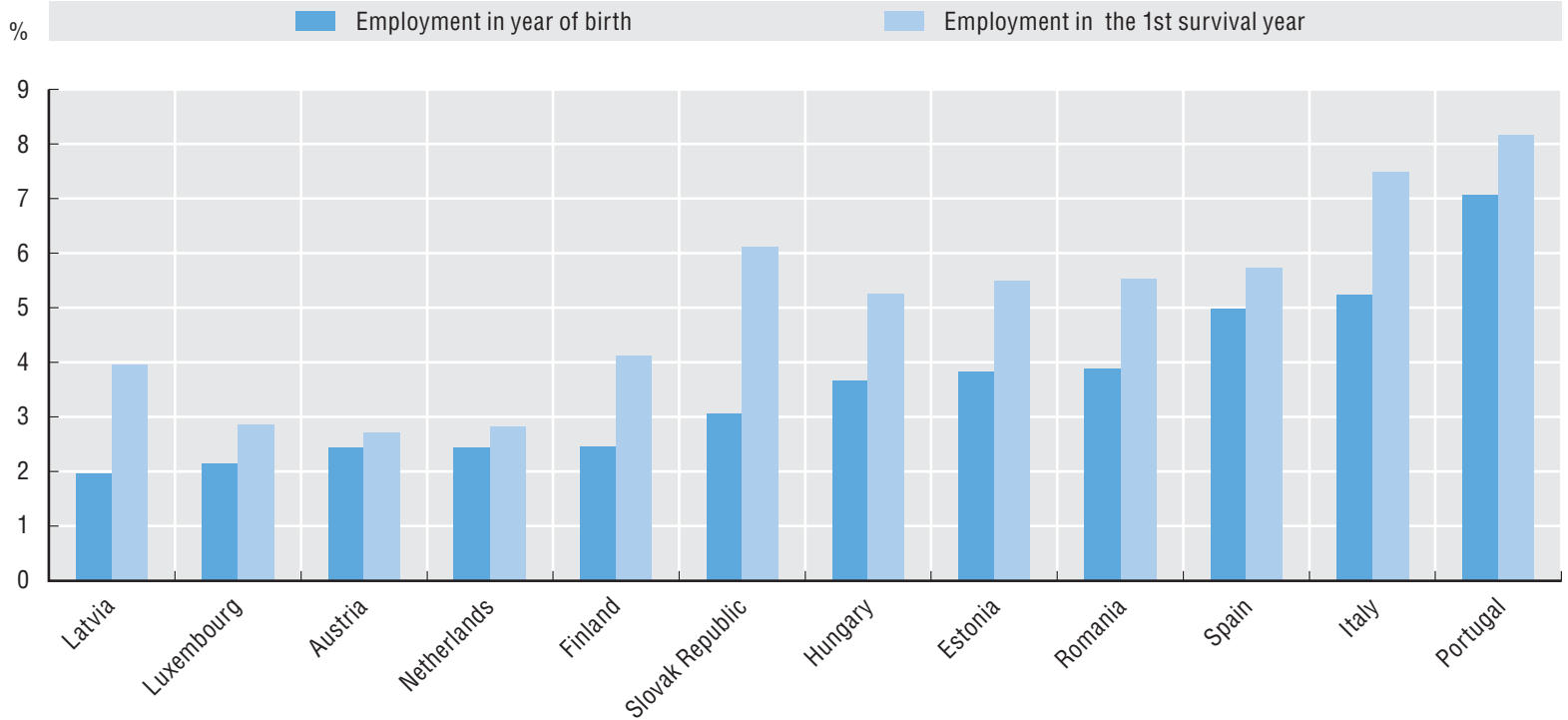

Figure 10.2. Employment in year of birth and in the 2nd survival year in all industries, enterprises that have survived 2 years in 2007, as a percentage of employment in the population of active enterprises

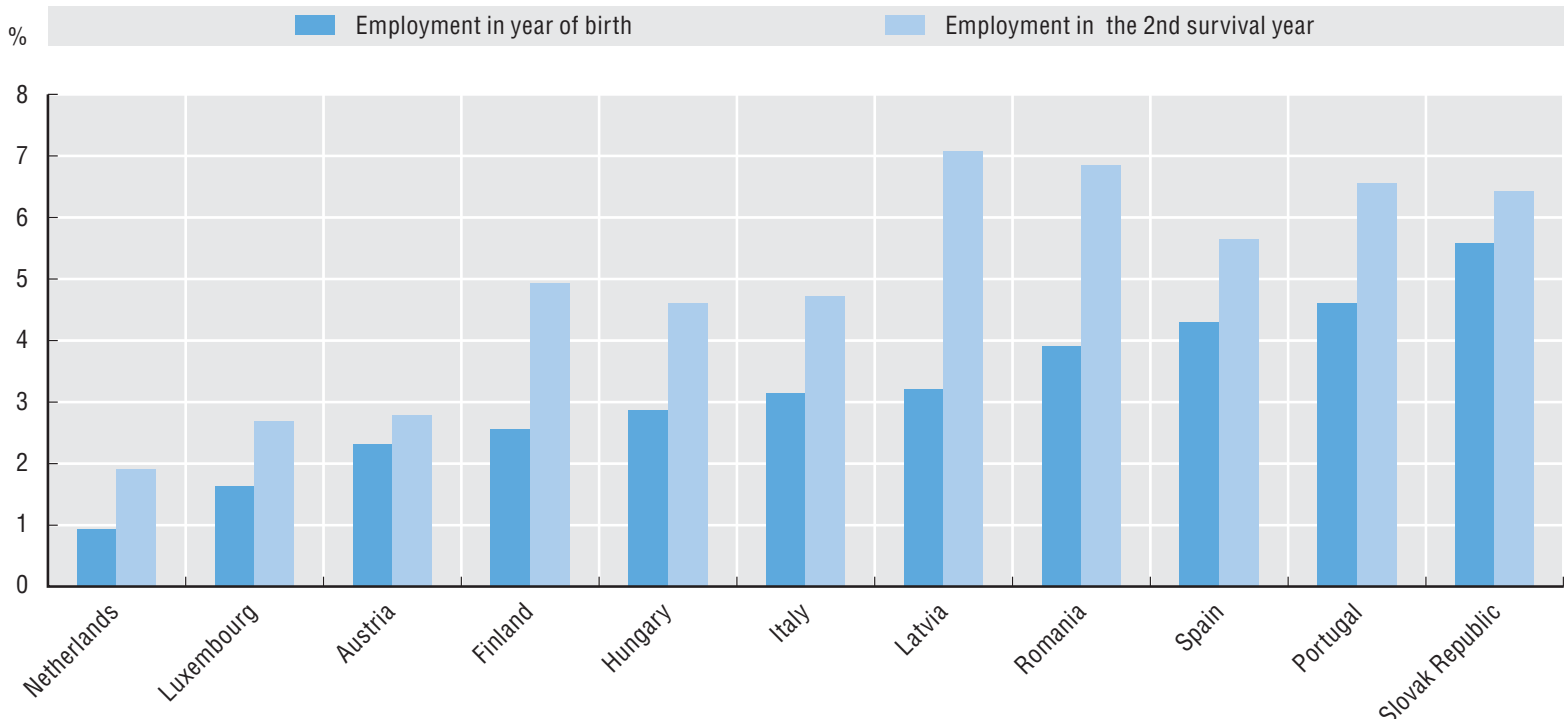


4.46

.13

300238

$\frac{3.72}{1.89}$

the 500 . 49

उदs 25 ? 200

$B$

20

(x)

tas 
ENTERPRISE GROWTH

11. High-growth enterprises rate

12. Gazelles rate

13. Distribution of enterprises by growth rate

ENTREPRENEURSHIP AT A GLANCE 2011 ○ OECD 2011

73 
High-growth enterprises are firms that by their extraordinary growth make the largest contribution to net job creation, despite typically representing a small proportion of the business population. With their presence in the economy considered promising for the creation of more jobs and innovation, interest in high-growth firms is high among policy makers.

\section{Definition}

High-growth enterprises, as measured by employment (or by turnover), are enterprises with average annualised growth in employees (or in turnover) greater than $20 \%$ a year, over a three-year period, and with ten or more employees at the beginning of the observation period.

The share of high-growth enterprises is compiled as the number of high-growth enterprises as a percentage of the population of enterprises with ten or more employees.

\section{Comparability}

A size threshold of ten employees at the start of any observation period was set to avoid the small size class bias that the above definition of high growth inevitably contains. The optimal threshold in terms of firm size at start, growh rate and growth period needs to balance two competing criteria: the first is to provide as detailed and as meaning ful information as possible, and the second is to maximise information that can be disclosed, i.e. that satisfies confidentiality rules and allows producing the indicators at as detailed an industry level as possible, and by standard (employment) size classes.

Setting the employment thresholds too low, for example, will reduce disclosure problems but at the same time result in disproportionate numbers of small enterprises appearing in the statistics. Too high, however, and disclosure problems increase, particularly for smaller economies, with significantly less large companies than larger economies. It is clear that an absolute threshold will affect countries and industries differently, depending on their size.

The size threshold of ten or more employees holds for both the turnover and employment measures. The advantage is that the initial population is the same, regardless of whether growth is measured in employment or turnover. Moreover, it would be difficult to apply a consistent turn- over threshold across all countries because of exchange rates, inflation, etc.

Data for Canada refer to employer enterprises with less than 250 employees.

Manufacturing data for Canada exclude Mining and Utilities.

\section{Highlights}

High-growth enterprises represent on average a small share of the total population, typically between 3.5\% and $6 \%$ when measured by employment growth; the proportion of enterprises that show high growth in turnover is higher with percentages going up to 20 and even more. Also, in most countries highgrowth firms (by employment) are in general more frequent in services, while their prevalence is higher in manufacturing when high-growh is measured by turnover.

\section{Source/Online database}

OECD Structural and Demographic Business Statistics (SDBS) Database.

\section{For further reading}

OECD (2010), Structural and Demographic Business Statistics, OECD Publishing, Paris.

http://dx.doi.org/10.1787/9789264072886-en

Eurostat/OECD (2007), Eurostat-OECD Manual on Business Demography Statistics, OECD, Paris.

Ahmad, N. and D. Rude Petersen (2007), High-Growth Enterprises and Gazelles - Preliminary and Summary Sensitivity Analysis, OECD-FORA, Paris.

The OECD Entrepreneurship Indicators Programme: Workshop on the Measurement of High-growth Enterprises, 19 November 2007, Paris.

www.oecd.org/document/31/

0,3746,en_2825_499554_39151327_1_1_1_1,00.html

Ahmad, N. and E. Gonnard (2007), "High-growth Enterprises and Gazelles", paper prepared for the International Consortium on Entrepreneurship (ICE), Copenhagen, Denmark. http://ice.foranet.dk/upload/highgrowth.pdf

Information on data for Israel:

http://dx.doi.org/10.1787/888932315602 
Figure 11.1. Share of high-growth enterprises (employment definition) in 2007

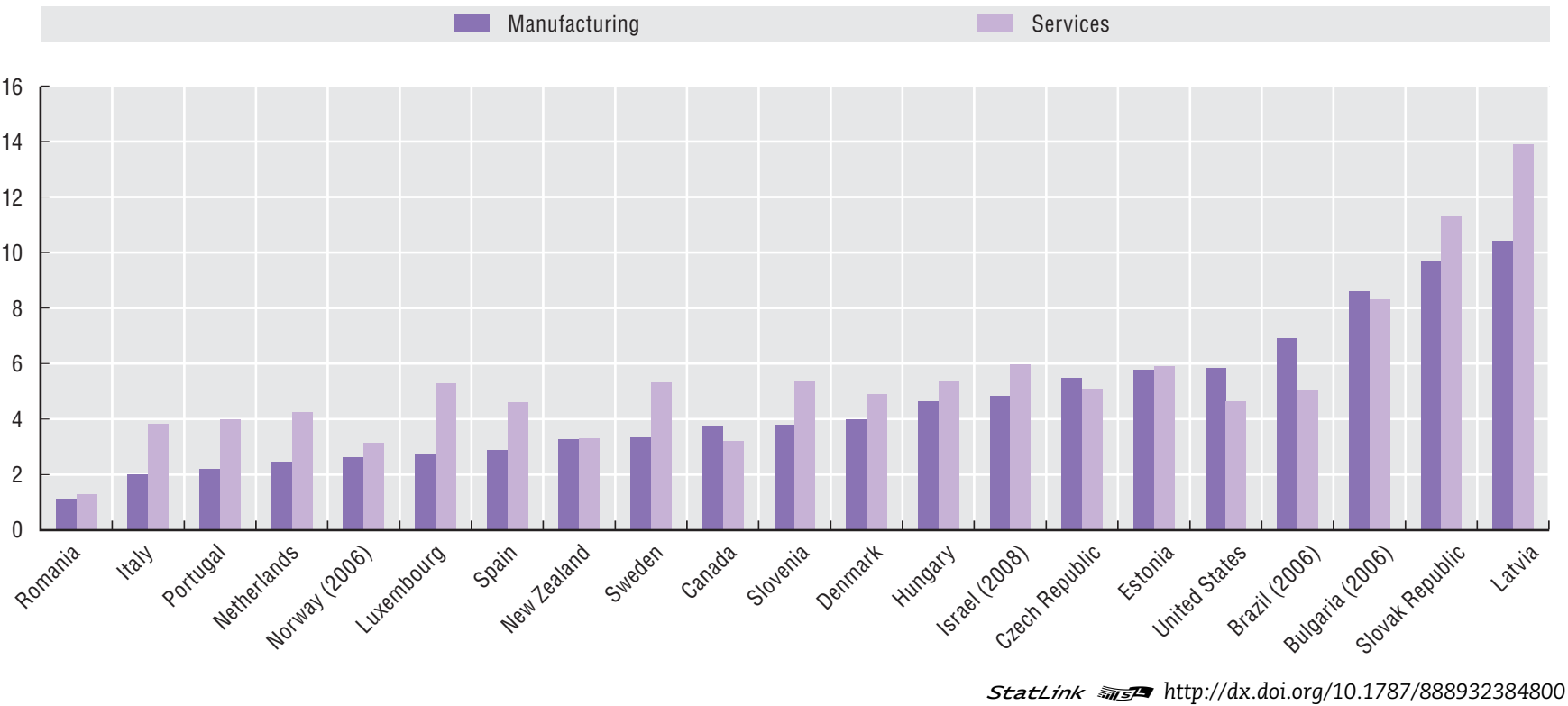

Figure 11.2. Share of high-growth enterprises (turnover definition) in 2007

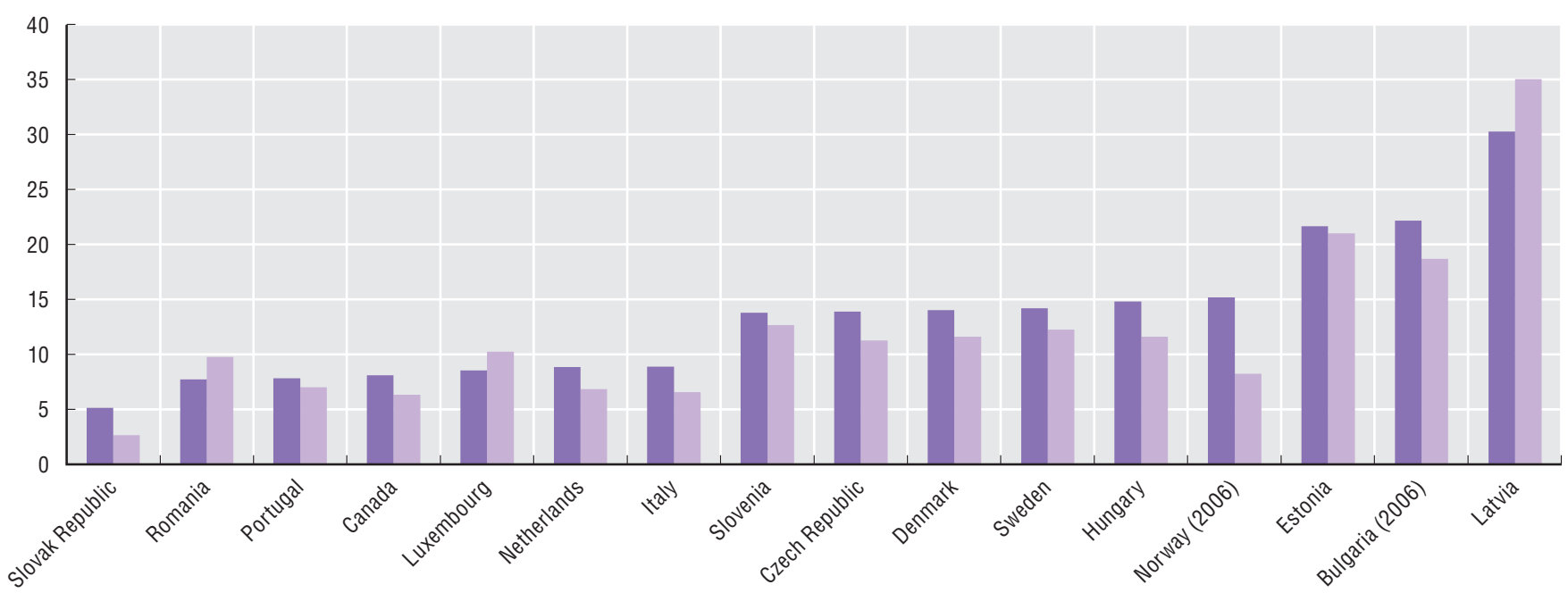




\section{ENTERPRISE GROWTH}

\section{Gazelles rate}

Gazelles represent the young enterprises among the population of high-growth enterprises. Their role in job creation is of particular interest to policy makers.

\section{Definition}

Gazelles form a subset of the group of high-growth enterprises; they are high-growth enterprises born five years or less before the end of the three-year observation period.

Measured in terms of employment (or turnover), gazelles are enterprises which have been employers for a period of up to five years, with average annualised growth in employees (or in turnover) greater than $20 \%$ a year over a three-year period and with ten or more employees at the beginning of the observation period.

The share of gazelles is expressed as a percentage of the population of enterprises with ten or more employees.

\section{Comparability}

Data for Canada refer to employer enterprises with less than 250 employees.

Manufacturing data for Canada exclude Mining and Utilities.

\section{Highlights}

In a majority of countries, less than $1 \%$ (or even less than $0.5 \%$ ) of the firms with ten or more employees are gazelles when the growth measure is based on employement; the share is slightly higher for gazelles as measured by turnover growth. Only in a few European ex-transition economies gazelles represent a share up to $4 \%$, depending on the growth criteria. To be noted, the shares have been stable over the past three years of data collection.

\section{Source/Online database}

OECD Structural and Demographic Business Statistics (SDBS) Database.

http://dx.doi.org/10.1787/sdbs-data-en

\section{For further reading}

OECD (2010), Structural and Demographic Business Statistics, OECD Publishing, Paris.

http://dx.doi.org/10.1787/9789264072886-en

Eurostat/OECD (2007), Eurostat-OECD Manual on Business Demography Statistics, OECD, Paris.

Ahmad, N. and D. Rude Petersen (2007), High-Growth Enterprises and Gazelles - Preliminary and Summary Sensitivity Analysis, OECD-FORA, Paris.

Ahmad, N. and E. Gonnard, (2007), "High-growth Enterprises and Gazelles", paper prepared for the International Consortium on Entrepreneurship (ICE), Copenhagen, Denmark. http://ice.foranet.dk/upload/highgrowth.pdf

The OECD Entrepreneurship Indicators Programme: Workshop on the Measurement of High-growth Enterprises, 19 November 2007, Paris.

www.oecd.org/document/31/

0,3746,en_2825_499554_39151327_1_1_1_1,00.html

Information on data for Israel:

http://dx.doi.org/10.1787/888932315602 
Figure 12.1. Share of gazelles (employment definition) in 2007

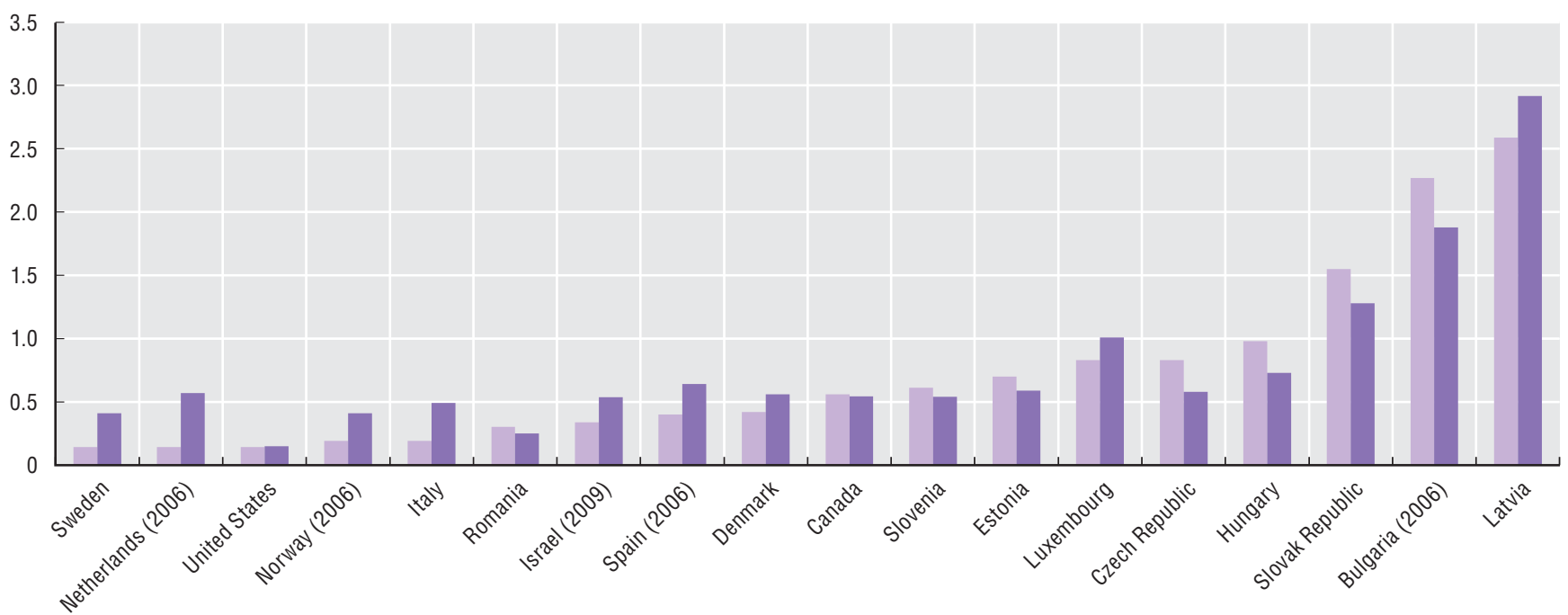

StatLink AाI $h$ ttp://dx.doi.org/10.1787/888932384838

Figure 12.2. Share of gazelles (turnover definition) in 2007

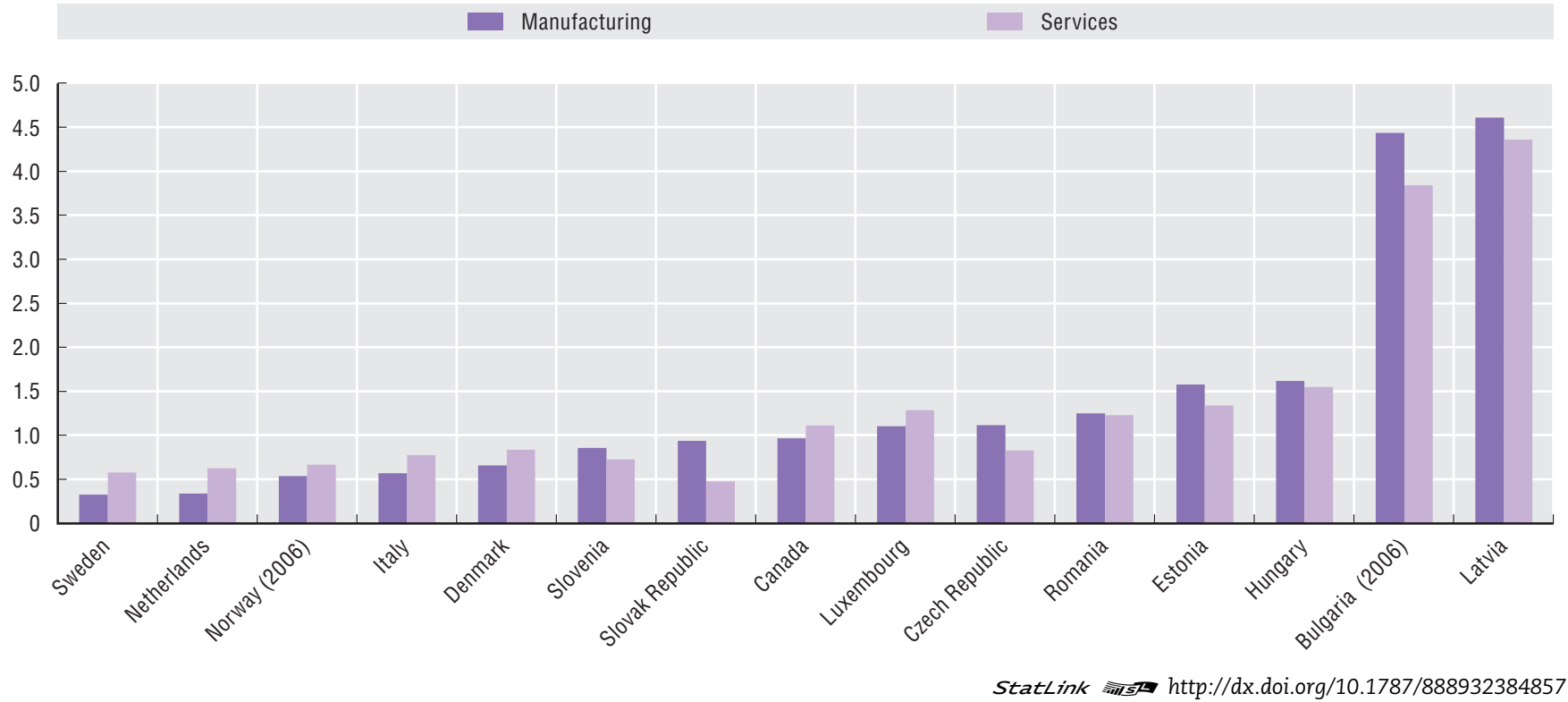




\section{ENTERPRISE GROWTH}

\section{Distribution of enterprises by growth rate}

The distribution of enterprises by rate of growth is an important indicator of the heterogeneity of business dynamics. It contributes to the analysis, for example, of job creation and productivity.

\section{Definition}

The indicators presented measure the distribution of firm growth over a three year period. An average annualised growth, in terms of the number of employees, is measured for each firm and, based on this, enterprises are allocated into one of the eleven intervals of growth set, i.e. from less than $-20 \%$ to more than $+20 \%$ employment growth per annum.

In Figure 13.1, each column reflects the share of enterprises with ten or more employees with average annual employment growth over a three-year period falling in a given growth interval.

For each country, the share of high-growth firms corresponds to the column at the top of the growth distribution.

\section{Comparability}

High-growth enterprises follow the definition of the EurostatOECD Manual on Business Demography Statistics, i.e. enterprises with average annualised growth in employees greater than $20 \%$ a year, over a three-year period, and with ten or more employees at the beginning of the observation period. However, data in Figure 13.1 are expressed as the share of firms in each growth interval relative to all surviving firms with ten or more employees at the beginning of the period. For a same country, the share of firms in the "more than $20 \%$ " interval is therefore not directly comparable with the share shown in the section "high-growth enterprises" of this publication, which reports the share of high-growth firms relative to the total population of active enterprises in the reporting year with at least ten employees.

Data refer to the population of firms with 10 or more employees, with the exception of Canada, for which data refer to enterprises with 10 or more employees and less than 250 employees.

\section{Highlights}

In European countries a large share of enterprises remain stable over time, while the distribution of firm growth in the United States indicates that US enterprises expand and contract faster.

\section{Source}

Bravo Biosca, A. (2010), "Growth Dynamics”, FORA-NESTA Research Report.

\section{For further reading}

Bravo Biosca, A. (2010), "Growth Dynamics: Exploring business growth and contraction in Europe and the US". Research Report, London: FORA and NESTA.

Bravo-Biosca, A. (2010), "Firm growth dynamics across countries: Evidence from a new database", Mimeo, November 2010, London: NESTA.

Eurostat/OECD (2007), Eurostat-OECD Manual on Business Demography Statistics, OECD, Paris.

Ahmad, N. and D. Rude Petersen (2007), High-Growth Enterprises and Gazelles - Preliminary and Summary Sensitivity Analysis, OECD-FORA, Paris. 
13. Distribution of enterprises by growth rate

Figure 13.1. Distribution by employment growth class (2002-2005)
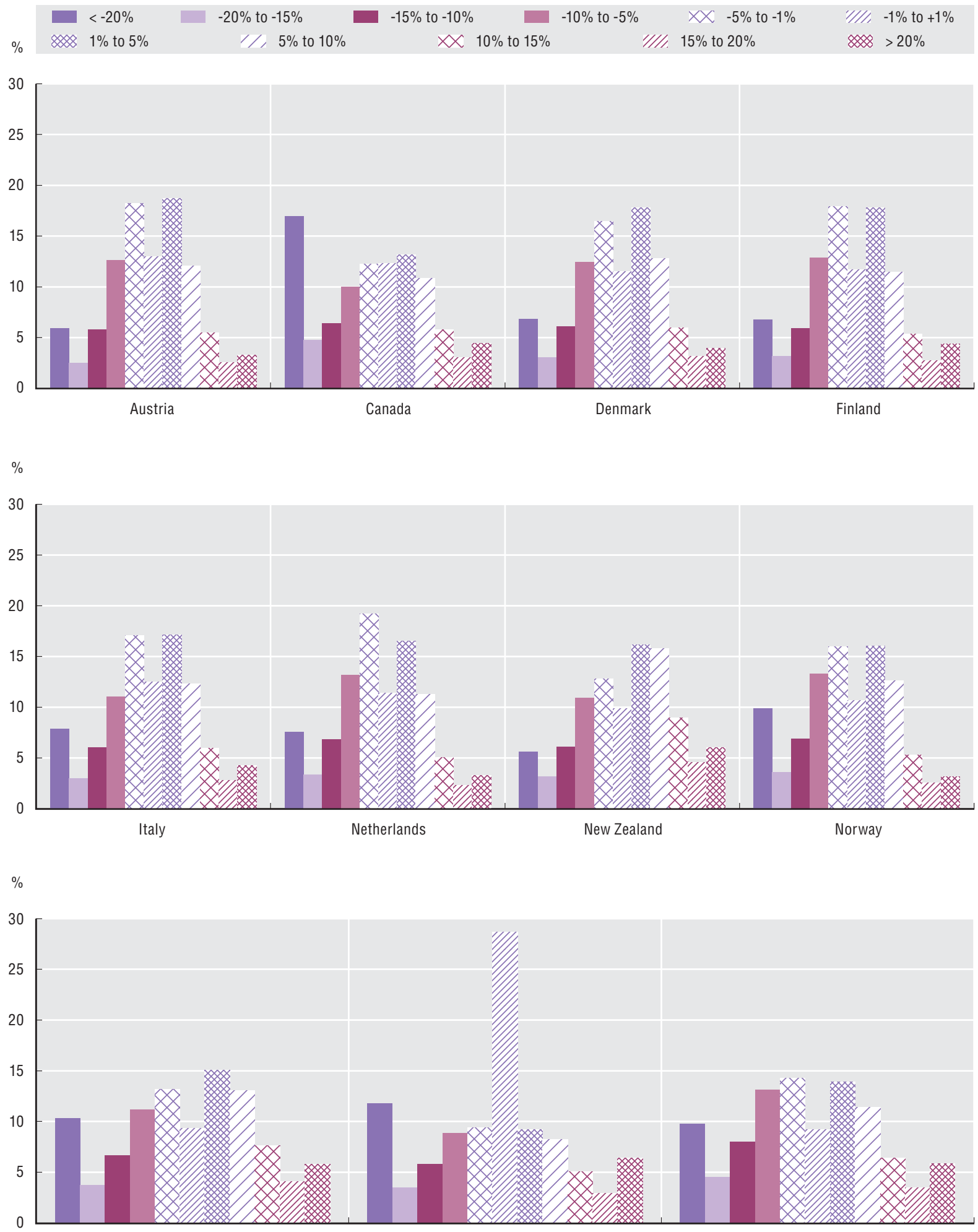

Spain

United Kingdom

United States

StatLink तiाs http://dx.doi.org/10.1787/888932386187 



\section{TIMELY INDICATORS OF ENTREPRENEURSHIP}

14. Number of new enterprises

15. Distribution of new enterprises by industrial activity

16. Number of bankruptcies 


\section{Number of new enterprises}

The recent global crisis has heightened interest in entrepreneurship as an essential element to foster economic recovery and employment growth. In order to analyse the impacts of economic cycles on new firm creation policymakers and analysts need as up-to-date as possible data. The indicators presented in this section respond to this need.

\section{Definition}

The Timely Indicators of Entrepreneurship database uses data based on national definitions only. When possible, adjustments are made to get as close as possible to the Eurostat-OECD Manual on Business Demography Statistics standard definitions (for example by removing agriculture and public companies, exclude inactive companies, etc.).

Some of the national sources selected for the timely indicators use the concept of enterprise birth, while others use the broader concept of enterprise creation.

An enterprise creation refers to the emergence of a new production unit. This can be either due to a real birth of the unit, or due to other creation by a merger, break-up, split-off or discontinuity point according to the continuity rules.

Sources and definitions for enterprise entries used in the Timely Indicators of Entrepreneurship database are described in Table A.1, Annex II.A.

\section{Comparability}

Since a single source is used, rather than the multiple sources used for national business registers, the population of enterprises is often incomplete. Depending on the country, the chosen single source may not cover certain legal forms of enterprises (e.g., sole proprietor) or sectors of activity (e.g. agriculture or education) or enterprises below a certain turnover or employment threshold.

The concepts of enterprise "creation" and "failure" reflected in the data series differ across countries. The concept of enterprise birth is more restrictive than the concept of creation as it refers to a legal entity that appears for the first time with no other enterprise involved in the creation process. It excludes firm creations resulting from mergers or changes of name, type of activity or ownership.
Data from the Timely Indicators of Entrepreneurship database are meant to be used for direct comparisons across countries in terms of trends, but not in levels.

\section{Highlights}

The economic and financial crisis has had an important impact on the creation of new enterprises: after a significant decrease in the second half of 2008, the number of new enterprises started to recover around the first half of 2009 in most countries. However, by the second quarter of 2010, the number of newly created enterprises was still below its pre-crisis level in most countries.

\section{Notes}

In France a new individual enterprise status (régime de l'autoentrepreneur) was implemented in January 2009.

The trend-cycle is the underlying path or general direction reflected in data over the longer term, i.e. the combined long-term (trend) and medium-to-long-term (cycle) movements in the original series. In a time series, the trend-cycle is the component that represents variations of low frequency, the high frequency fluctuations having been filtered out. This component can be viewed as those variations with a period longer than a chosen threshold (usually $1 \frac{1}{2}$ years is considered as the minimum length of the business cycle). In practice, the estimation of the trendcycle is done by estimating and removing the seasonal and irregular components from the original non-adjusted data. (see http://stats.oecd.org/glossary/detail.asp?ID=6693)

\section{Source/Online database}

OECD Timely Indicators of Entrepreneurship (TIE) Database.

\section{For further reading}

Eurostat (2010), Estimation of recent business demography data, DOC.06/EN/EUROSTAT/G2/BD/JUN10.

OECD (2010), "Measuring Entrepreneurship", OECD Statistics Brief, No. 15.

www.oecd.org/dataoecd/50/56/46413155.pdf

UN (2008), International Standard Industrial Classification of All Economic Activities (ISIC), Rev. 4, 2008, United Nations, New York.

http://unstats.un.org/unsd/cr/registry/isic-4.asp 
Figure 14.1. Number of new enterprises, $2006=100$, trend-cycle
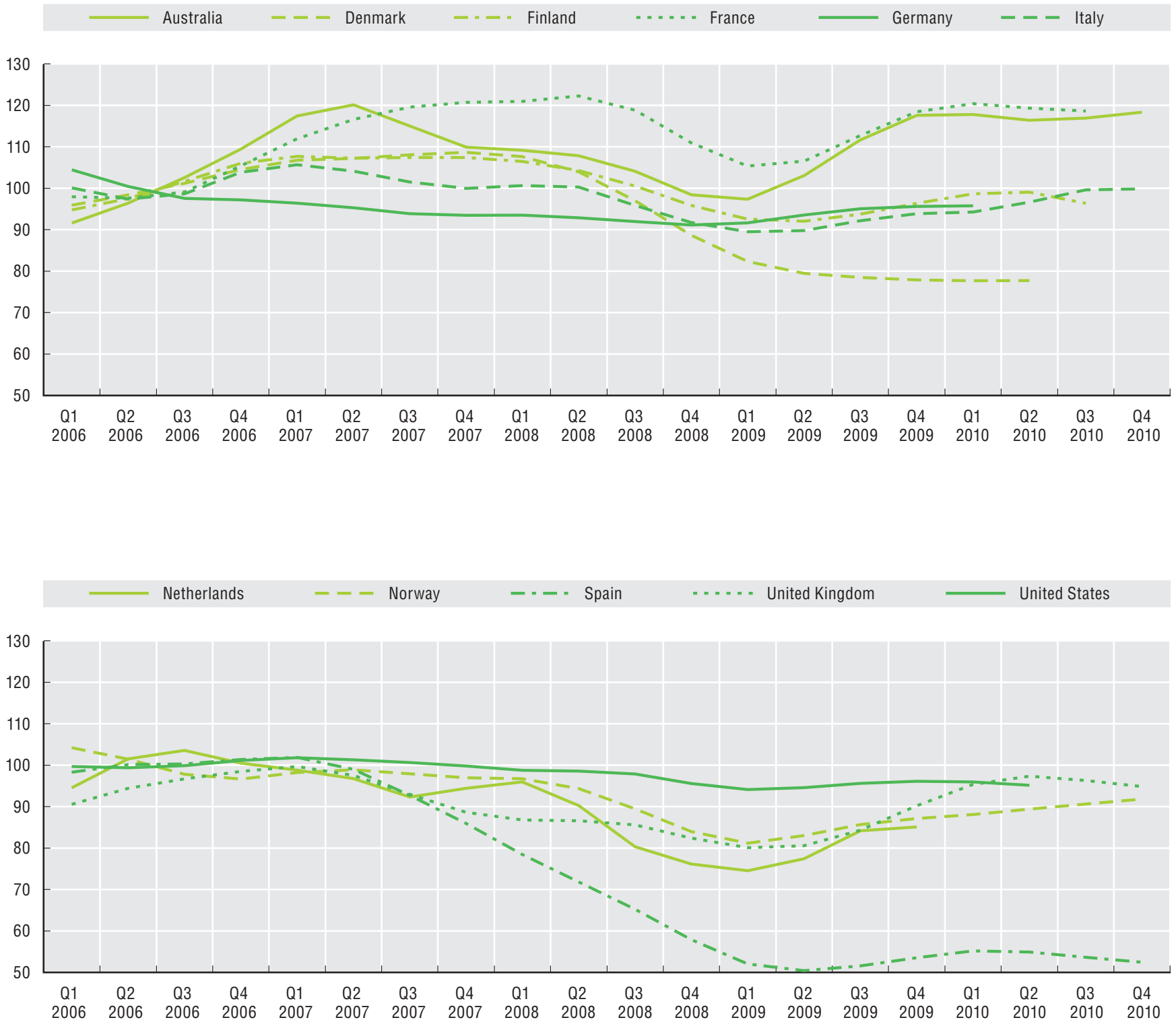

StatLink Aist http://dx.doi.org/10.1787/888932384876 


\section{Distribution of new enterprises by industrial activity}

\section{Definition}

The share of activities in enterprise creations are compiled as a number of new enterprises in each activity, as a percentage of the number of new enterprises in the total economy.

The year on year growth rates of new enterprise creations by activity are compiled as percentage differences between the number of enterprises created in a given quarter and the number of enterprises created during the same quarter in the previous year.

The distribution by industrial activity of new enterprises is presented in Table 15.1, while Table 15.2 shows the yearon-year changes of enterprise creation by activity. For international comparability purpose, data by activities in Tables 15.1 and 15.2 are presented according to the ISIC Rev. 4 international classification (or NACE Rev. 2 for European Union member states). Concordance relationships between ISIC Rev. 4 and national or other international systems are used to harmonised data presentation for every countries and every years. It should be noted however that it may happen that, for some sectors, there is no strict concordance between the original classification and the ISIC Rev. 4.

\section{Comparability}

The activity breakdown in Table 15.1 is typically based on the International Standard of Industrial Classification ISIC Revision 4 (ISIC) with some exceptions:

- in Germany and in Norway, before 2008, as well as in Italy for the whole period, it is close to NACE Rev. 1.
- For the United States, the breakdown is derived from the North American Industrial Classification System (NAICS).

- For Spain, annual data are taken from the CCD.

\section{Highlights}

In construction, trade and transport, the drop in the creation of new enterprises was particularly severe during the crisis. Finance and real estate also experienced significant declines in the number of new enterprises.

\section{Source/Online database}

OECD Timely Indicators of Entrepreneurship (TIE) Database.

\section{For further reading}

Eurostat (2010), Estimation of recent business demography data, DOC.06/EN/EUROSTAT/G2/BD/JUN10.

OECD (2010), "Measuring Entrepreneurship", OECD Statistics Brief, No. 15.

www.oecd.org/dataoecd/50/56/46413155.pdf

UN (2008), International Standard Industrial Classification of All Economic Activities (ISIC), Rev. 4, 2008, United Nations, New York.

http://unstats.un.org/unsd/cr/registry/isic-4.asp 


\section{TIMELY INDICATORS OF ENTREPRENEURSHIP}

15. Distribution of new enterprises by industrial activity

Table 15.1. New enterprises by activity; percentage of total activity

\begin{tabular}{|c|c|c|c|c|c|c|c|c|c|c|c|c|c|c|}
\hline $\begin{array}{c}\text { Activities } \\
\text { ISIC Rev. } 4 \text { /NACE Rev. } 2\end{array}$ & \multicolumn{2}{|c|}{ Finland } & \multicolumn{2}{|c|}{ France } & \multicolumn{2}{|c|}{ Germany } & \multicolumn{2}{|c|}{ Italy } & \multicolumn{2}{|c|}{ Norway } & \multicolumn{2}{|c|}{ Spain } & \multicolumn{2}{|c|}{ USA } \\
\hline 10_33: Manufacturing & 6 & 5 & 5 & 4 & 6 & 5 & 7 & 7 & 4 & 3 & 4 & 3 & 2 & 3 \\
\hline $\begin{array}{l}\text { 45_47: Wholesale and retail trade; repair of motor } \\
\text { vehicles and motorcycles }\end{array}$ & 17 & 18 & 24 & 22 & 30 & 29 & 20 & 22 & 12 & 13 & 20 & 23 & 14 & 14 \\
\hline 49_53: Transportation and storage & 4 & 4 & 2 & 1 & 4 & 3 & 2 & 2 & 3 & 4 & 5 & 4 & 2 & 2 \\
\hline 58_63: Information and communication & 5 & 5 & 4 & 5 & .. & 4 & .. & .. & .. & 7 & 2 & 2 & 2 & 2 \\
\hline 64_66: Financial and insurance activities & 1 & 1 & 4 & 2 & 2 & 4 & 2 & 2 & 5 & 4 & 2 & 3 & 5 & 4 \\
\hline 68: Real estate activities & 6 & 4 & 5 & 3 & 5 & 4 & 2 & 2 & 14 & 7 & 5 & 4 & 4 & 4 \\
\hline $\begin{array}{l}\text { 69_82: Professional, scientific, technical and other } \\
\text { business support activities }\end{array}$ & 21 & 23 & 17 & 22 & 21 & 18 & 6 & 6 & 21 & 21 & 17 & 19 & 23 & 24 \\
\hline 85_88: Education, health and social work activities & 5 & 5 & 8 & 9 & 2 & 2 & 0 & 0 & 9 & 12 & 5 & 6 & 8 & 8 \\
\hline
\end{tabular}

StatLink AाISt $h t t p: / / d x . d o i . o r g / 10.1787 / 888932385332$

Table 15.2. New enterprises by activity, year-on-year growth rates

\begin{tabular}{|c|c|c|c|c|c|c|c|c|c|c|}
\hline & \multicolumn{2}{|c|}{ Finland } & \multicolumn{2}{|c|}{ Germany } & \multicolumn{2}{|c|}{ Italy } & \multicolumn{2}{|c|}{ Norway } & \multicolumn{2}{|c|}{ USA } \\
\hline 41_43: Construction & -36 & 18 & 6 & 3 & -16 & -7 & -30 & 14 & -8 & 4 \\
\hline $\begin{array}{l}\text { 45_47: Wholesale and retail trade; repair of motor } \\
\text { vehicles and motorcycles }\end{array}$ & -13 & 2 & 4 & -2 & -1 & 5 & -11 & 23 & -6 & -5 \\
\hline 58_63: Information and communication & -10 & -5 & -7 & 4 & .. & 4 & 4 & 11 & 6 & -11 \\
\hline 64_66: Financial and insurance activities & -19 & -1 & 6 & -6 & -11 & 2 & -37 & 27 & -14 & -2 \\
\hline 68: Real estate activities & -26 & -4 & -5 & -5 & -21 & -2 & -37 & 16 & -8 & -4 \\
\hline 69_82: Business services & -11 & 4 & 3 & -5 & -3 & 4 & -7 & 5 & -2 & 1 \\
\hline 85_88: Education and Health & -9 & 9 & 13 & -13 & 7 & -3 & -8 & 21 & 0 & 3 \\
\hline
\end{tabular}

StatLink ला/sय http://dx.doi.org/10.1787/888932385351 


\section{Definition}

Bankruptcy is used as an alternative indicator for enterprise deaths.

Sources for bankruptcies data used for the Timely Indicators of Entrepreneurship Database are described in Table A.2, Annex II.A.

\section{Comparability}

Bankruptcy laws differ across countries. In some countries a declaration of bankruptcy means that the enterprise must stop trading immediately. In other countries, enterprises can declare themselves as bankrupt but are able to continue trading with receivers in operational control. This results in the winding-up of the enterprise as it goes into liquidation but sometimes the enterprise is able to continue operating, albeit with more restrictive operations and under new management. This means that some enterprises on business registers, may be active but also bankrupt, making it very difficult to use a concept of deaths based on bankruptcy, particularly as some nominally bankrupt companies may recover.

On the other hand, firm closures can be due to different reasons, and only some consist of liquidations following bankruptcy. The financial literature has highlighted that countries differ in terms of the probabilities of firms being involved in bankruptcy or other insolvency procedures, and also in the final results of these procedures. The proportion of bankruptcy procedures that end up in actual liquidations of the companies, and not in reorganisations, varies across countries depending on the bankruptcy code.

\section{Highlights}

Recent available data reveal similar patterns across countries: between the first quarter of 2008 and the second quarter of 2009, the number of bankruptcy procedures increased considerably across countries and continued at high levels until the second quarter of 2010.

\section{Notes}

The trend-cycle is the underlying path or general direction reflected in data over the longer term, i.e. the combined long-term (trend) and medium-to-long-term (cycle) movements in the original series. In a time series, the trend-cycle is the component that represents variations of low frequency, the high frequency fluctuations having been filtered out. This component can be viewed as those variations with a period longer than a chosen threshold (usually $1 \frac{1}{2}$ years is considered as the minimum length of the business cycle). In practice, the estimation of the trendcycle is done by estimating and removing the seasonal and irregular components from the original non-adjusted data. (see http://stats.oecd.org/glossary/detail.asp?ID=6693)

\section{Source/Online database}

OECD Timely Indicators of Entrepreneurship (TIE) Database.

\section{For further reading}

Eurostat (2010), Estimation of recent business demography data, DOC.06/EN/EUROSTAT/G2/BD/JUN10.

OECD (2010), "Measuring Entrepreneurship", OECD Statistics Brief, No. 15.

www.oecd.org/dataoecd/50/56/46413155.pdf 
Figure 16.1. Number of bankruptcies, average $2006=100$, Trend-Cycle
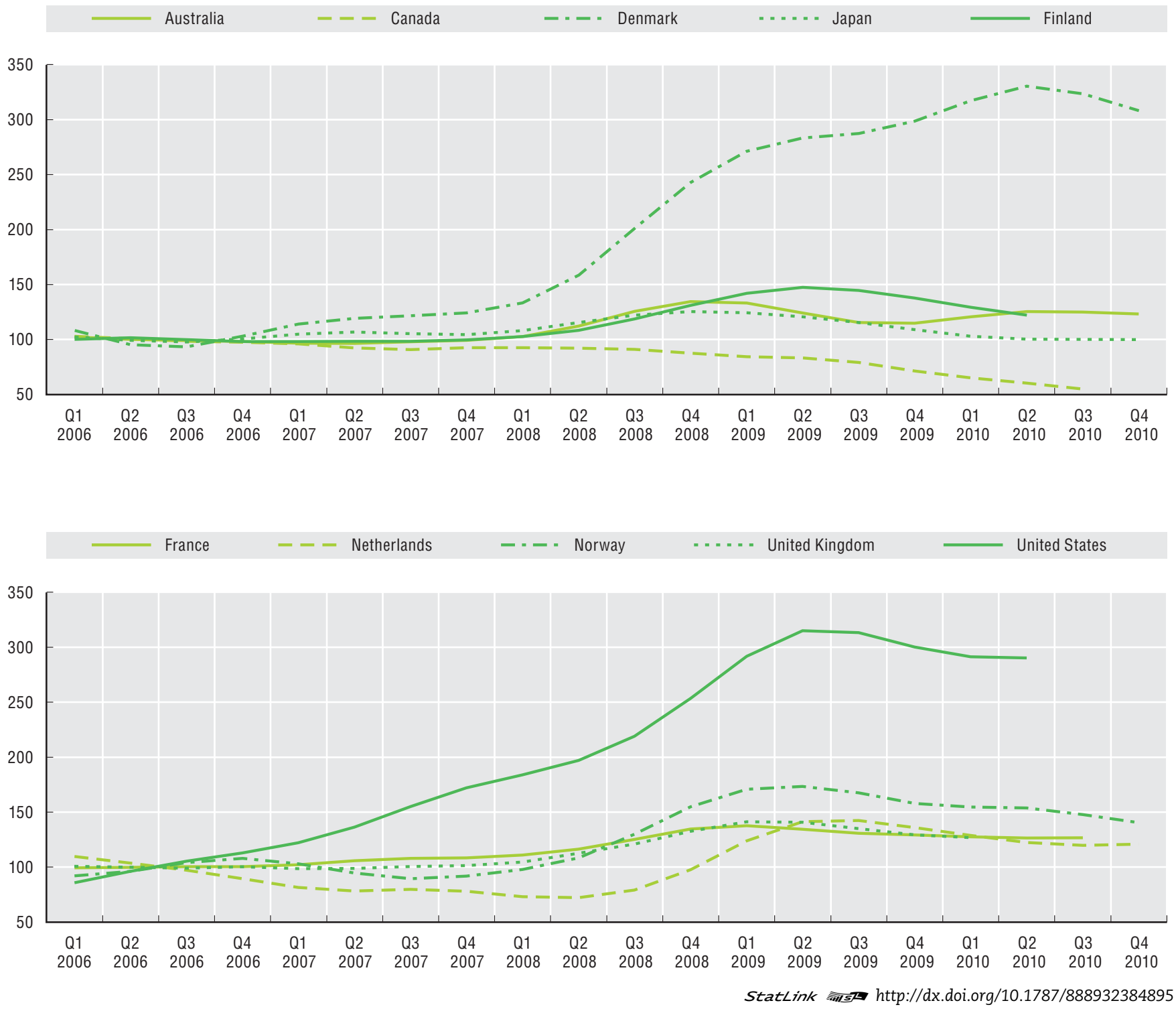
4.463 .72
$2.28 \times 20$

8002281.89

145.004 .15 ?

$B$

5

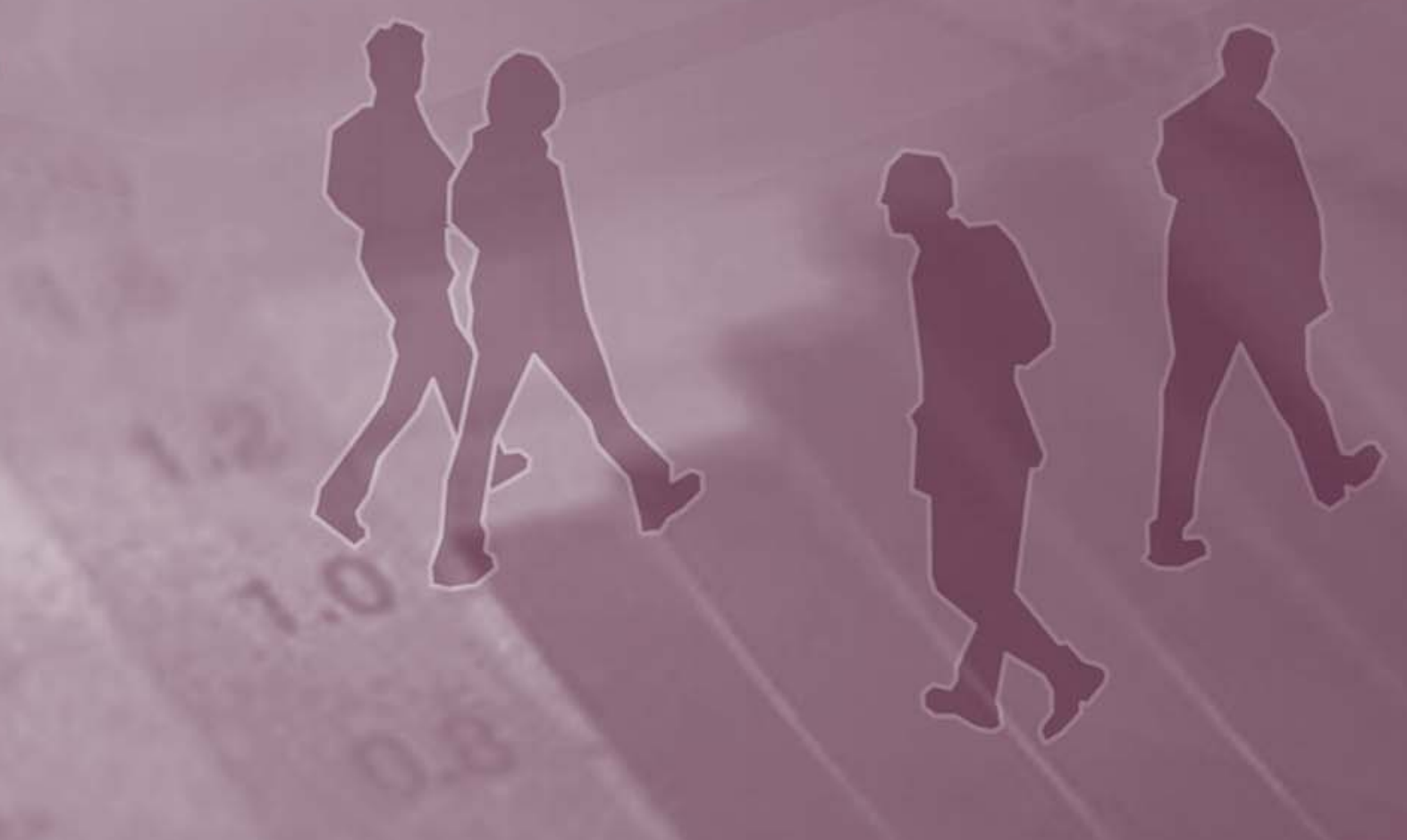

$+2$ 25 ?.05

$$
\begin{array}{r}
7.24 \\
314
\end{array}
$$

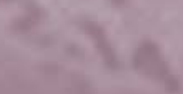


WOMEN ENTREPRENEURSHIP

17. Entrepreneurial activity by gender

18. Obstacles to entrepreneurship by gender

ENTREPRENEURSHIP AT A GLANCE 2011 ๑ OECD 2011

89 


\section{Entrepreneurial activity by gender}

The contribution of women to entrepreneurial activity is not yet well understood, one of the main problems being the lack of sound and reliable data on the gender dimension of entrepreneurship. Developing effective policies to improve gender equality in entrepreneurship requires the collection of comprehensive and internationally comparable data. This section presents indicators on gender differences in entrepreneurial performance from two different types of sources, namely an academic consortium and official statistics offices. The indicators are meant to be examples of the information currently available at the international level.

\section{Definition}

The overall business ownership rate measures the per cent of adult population (18-64 year old) who are either early-stage entrepreneurs (i.e. involved in owning and managing, alone or with others, a nascent business or one that has been in operation for 42 months or less) or established entrepreneurs (i.e. involved in owning and managing, alone or with others, a business that has successfully survived in the market beyond 42 months). It is presented by gender of the business owner.

The share of men and women by activity of the business owner describes the distribution by activity sector of men and women who are business owners.

\section{Comparability}

\section{Overall Business Owners rate, by gender}

41 countries participated in the 2007 GEM Report on Women Entrepreneurship. Run by national teams, the GEM survey is conducted among at least 2000 people within a country's adult population. GEM is a consortium of researchers. Each individual national team survey is expected to follow the same methodology and timing to ensure comparability.

\section{Activity of the business owner, by gender}

The Factor of Business Success (FOBS) study was a one-off project conducted by Eurostat in 2005 with the participation of 15 national statistics offices. The population surveyed included enterprises born in 2002 that had survived for 3 years, until the time of the survey in 2005, and that were still managed by their founders at the time of the survey. The samples were drawn from populations of newly born enterprises identified in business registers. The FOBS survey explored factors of success, factors that support or hamper the success of newly born enterprises.

The EU total refers to the following member states: Austria, Bulgaria, Czech Republic, Denmark, Estonia. France, Italy, Lithuania, Luxembourg, Latvia, Portugal, Romania, Sweden, Slovenia and Slovak Republic. The breakdown by sector follows the NACE classification (Classification of Economic Activities in the European Community). Total industry data do not include construction.

\section{Highlights}

The rate of women who are early-stage entrepreneurs or established entrepreneurs varies significantly across the 41 countries surveyed by GEM in 2007, ranging from $2.9 \%$ for Belgium to a $45.2 \%$ for Thailand.

Women-owned enterprises are more prevalent in services than in manufacturing. Women are very poorly represented in Construction and Transports, while their share as business owners in Hotel and Restaurants is almost equal to that of men.

\section{Sources}

Global Entrepreneurship Monitor 2007. Report on Women Entrepreneurship, Babson College.

www.gemconsortium.org/download/1299495710240/ GEM\%20GLOBAL\%20Womens\%20Report\%202007.pdf

Eurostat, Factors of Business Success.

http://epp.eurostat.ec.europa.eu/portal/page/portal/ european_business/special_sbs_topics/factors_business_success

\section{Further reading}

Eurostat (2006), The Profile of the Successful Entrepreneurs, Results of the survey "Factors of Business Success, Statistics in Focus”, 29/2006.

http://epp.eurostat.ec.europa.eu/cache/ITY_OFFPUB/KS-NP-06029/EN/KS-NP-06-029-EN.PDF

Information on data for Israel:

http://dx.doi.org/10.1787/888932315602 
Figure 17.1. Overall business ownership rate by gender, 2007

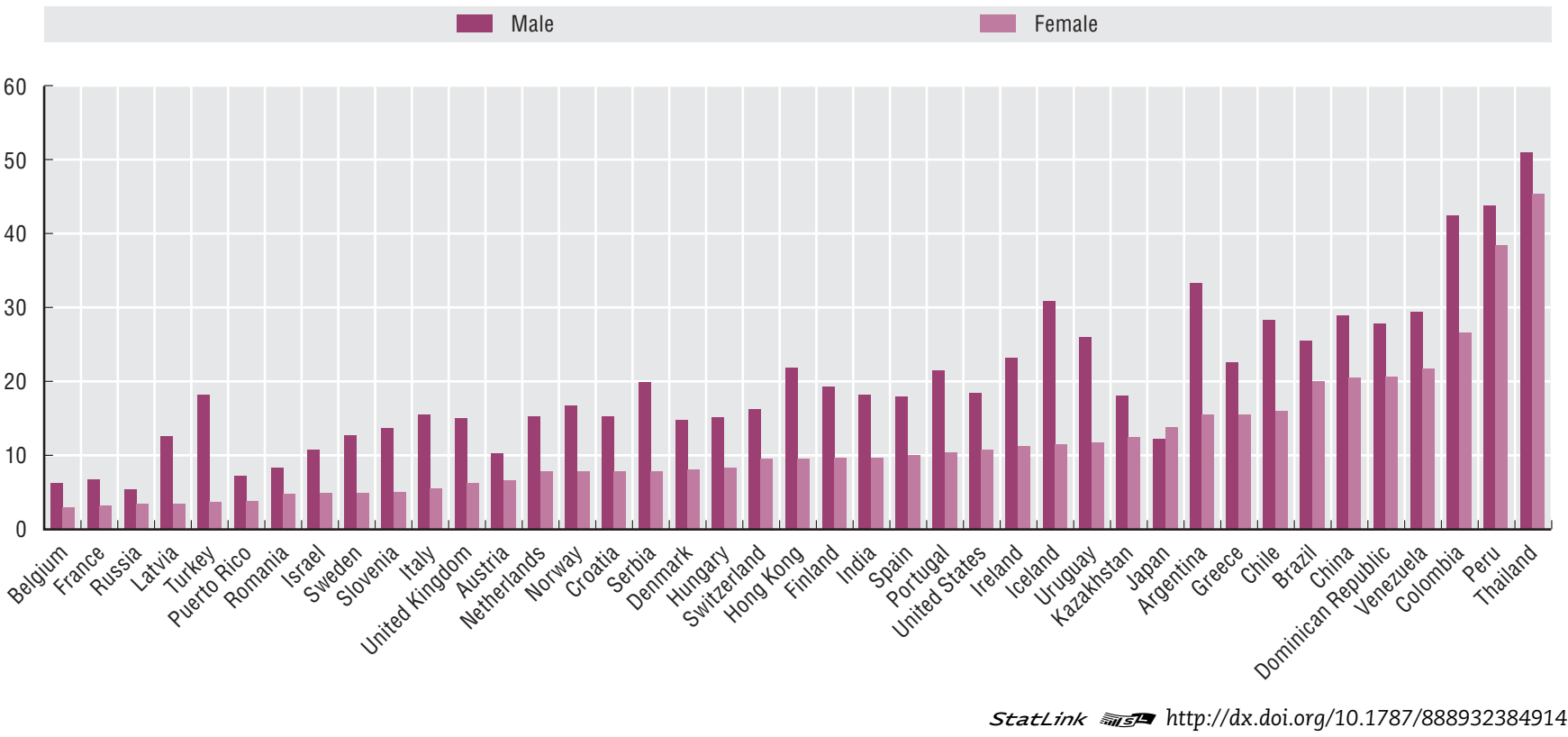

Figure 17.2. Share of men and women by activity of the business owner in 14 EU countries by gender, shares, 2005

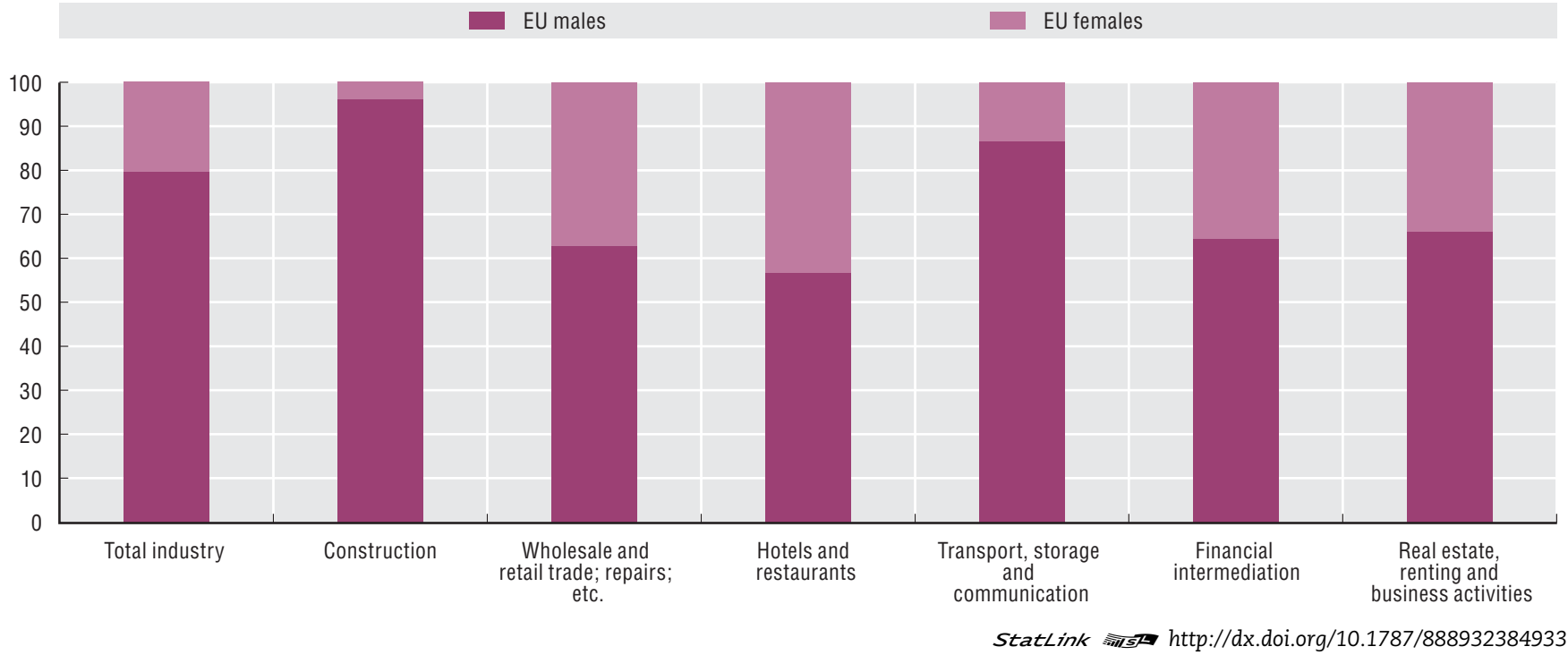




\section{Obstacles to entrepreneurship by gender}

Entrepreneurs face a range of obstacles when starting their business and growing it. If appropriate support has to be designed, knowing the gender differences in the perception and or experience of barriers is useful. This section looks at obstacles to entrepreneurship by gender, as reported by three official statistics sources. In a context of international comparisons, the perception of obstacles may be affected not only by the previous experience of the respondents (typically, individuals with entrepreneurial experience tend to be more aware of the difficulties if starting up or growing an enterprise) but also by cultural factors.

\section{Definitions}

Start-up difficulties record multiple answers to the question "What did you find difficult when starting up your enterprise?", where respondents choose among a list of given options.

Obstacles to business growth record multiple answers to the question "Which of the following obstacles are serious problems for the growth of your business?"; respondents choose among given options.

Obstacles to business success record multiple answers to the question "Which is the biggest obstacle to the success of your business"; respondents choose among given options.

\section{Comparability}

Eurostat FOBS (see previous section): The aggregate "EU" consists of the following 14 countries: Austria, Bulgaria, Czech Republic, Denmark, Estonia. Italy, Lithuania, Luxembourg, Latvia, Portugal, Romania, Sweden, Slovenia and Slovak Republic.

Canada: The Statistics Canada triennial Survey on Financing of Small and Medium Enterprises launched in 2001, measures the demand and sources for financing of Canadian SMEs, including data on the application process, firm profiles and demographic characteristics of SME ownership by gender. The most recent survey (2007) covered about 15000 responding firms operating in that year with fewer than 500 employees and less than USD 50 million in revenue (target population). Results cover seven industry groupings, five employment sizes, six geographic regions and start-ups compared with established firms.

A male (female) ownership is defined as a $100 \%$ male (female) ownership, hence excluding the 1 to 50 , or the 51 to $99 \%$ categories of ownership for both genders. The survey question "Which of the following obstacles are serious problems for the growth of your business?" applies to all SMEs under investigation

United Kingdom: Since 2003, the UK governmental department for Business Innovation and Skills (BIS) conducts an Annual Small Business Survey. Between December 2007 and February 2008, 7783 UK SME businesses with 1 to 249 employees were interviewed by telephone. The main purpose of the survey is to gauge the needs and concerns of small businesses and identify the barriers that prevent them from fulfilling their potential.

\section{Highlights}

There are no major differences in the way women and men business owners perceive obstacles either to start-up a business or to grow it. The types of obstacles identified as more relevant by men and women are the same across different surveys: when starting up, these include legal and administrative matters, developing contacts with customers and access to finance; subsequently, the obstacles to success come from the level of competition and of business costs, and the state of the economy. While overall the share of women facing a given obstacle is slightly superior than that of men, in a number of cases the pattern is reversed.

\section{Sources}

Eurostat, Factors of Business Success.

http://epp.eurostat.ec.europa.eu/portal/page/portal/ european_business/special_sbs_topics/factors_business_success

Statistics Canada 2007, Survey of Financing of Small and Medium Enterprises.

UK Annual Small Business Survey, BERR-Department of Business Enterprise and Regulatory Reform (Institute for Employment Study), 2007. 
Figure 18.1. Start-up difficulties by gender, 14 EU countries, 2005

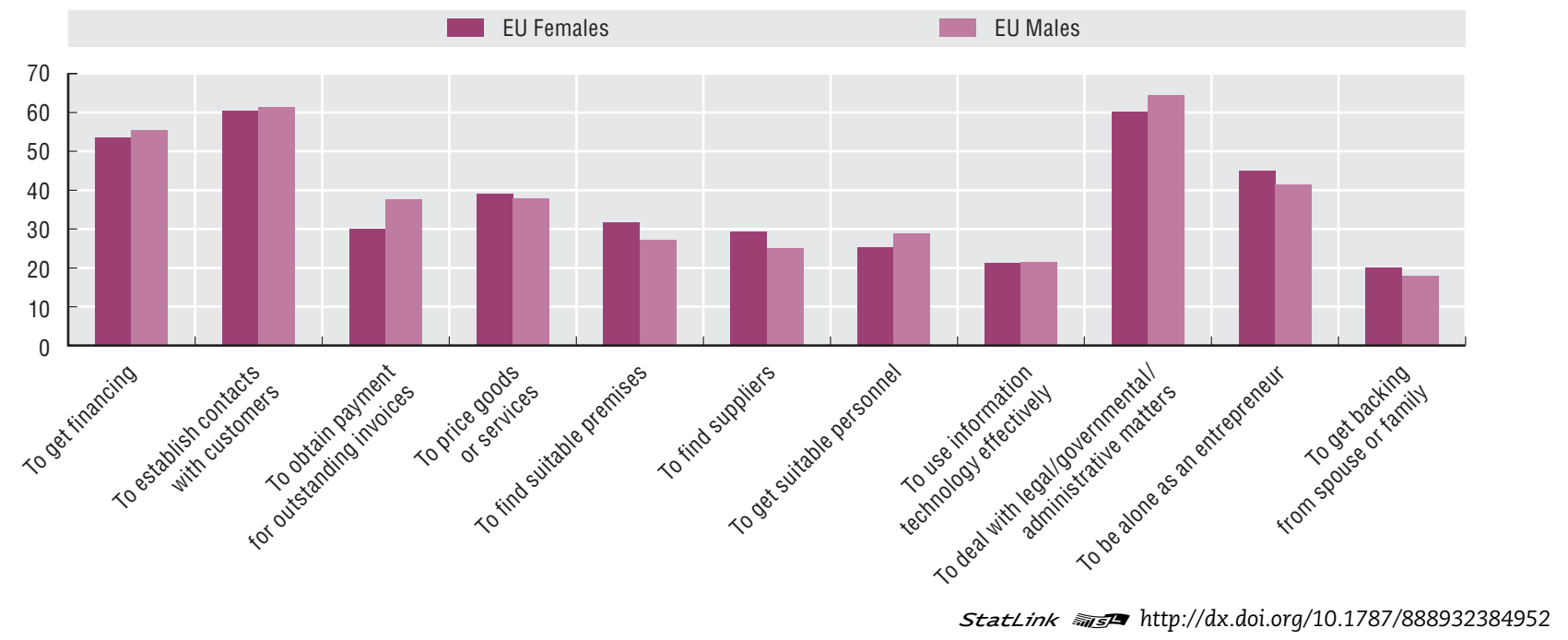

Figure 18.2. Obstacles to business growth by gender, Canada, 2007

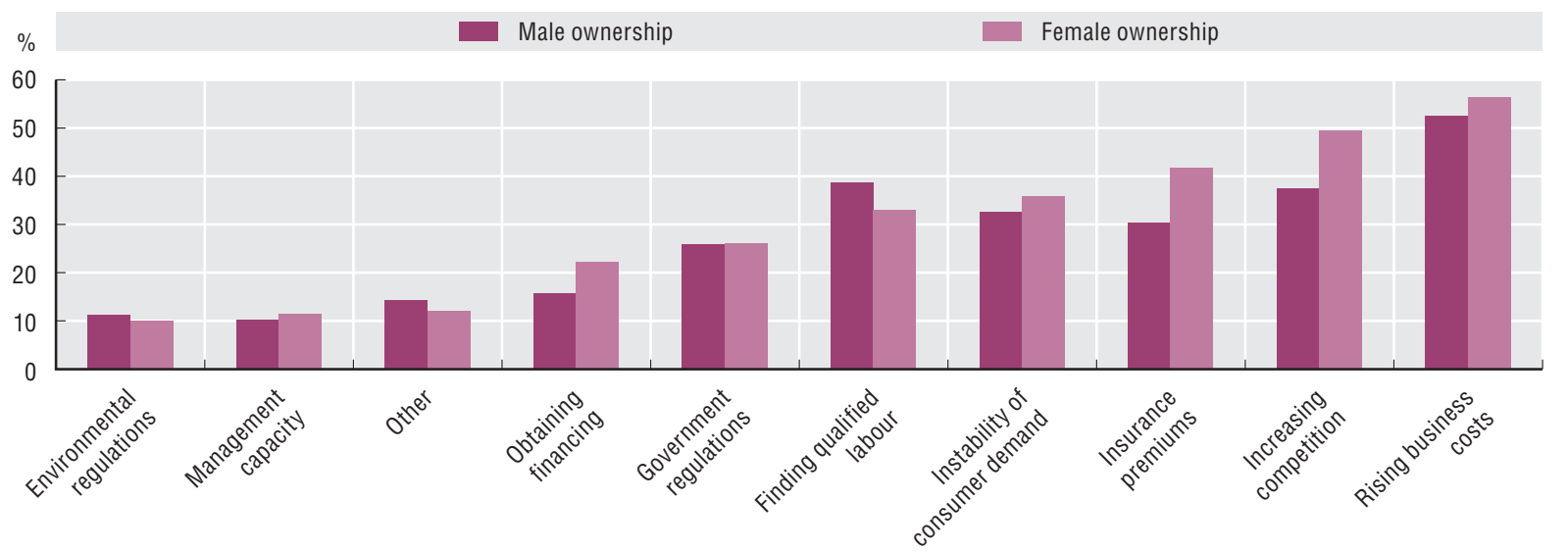

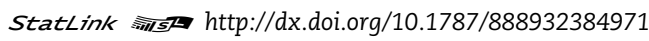

Figure 18.3. Obstacles to business success by gender, United Kingdom, 2007

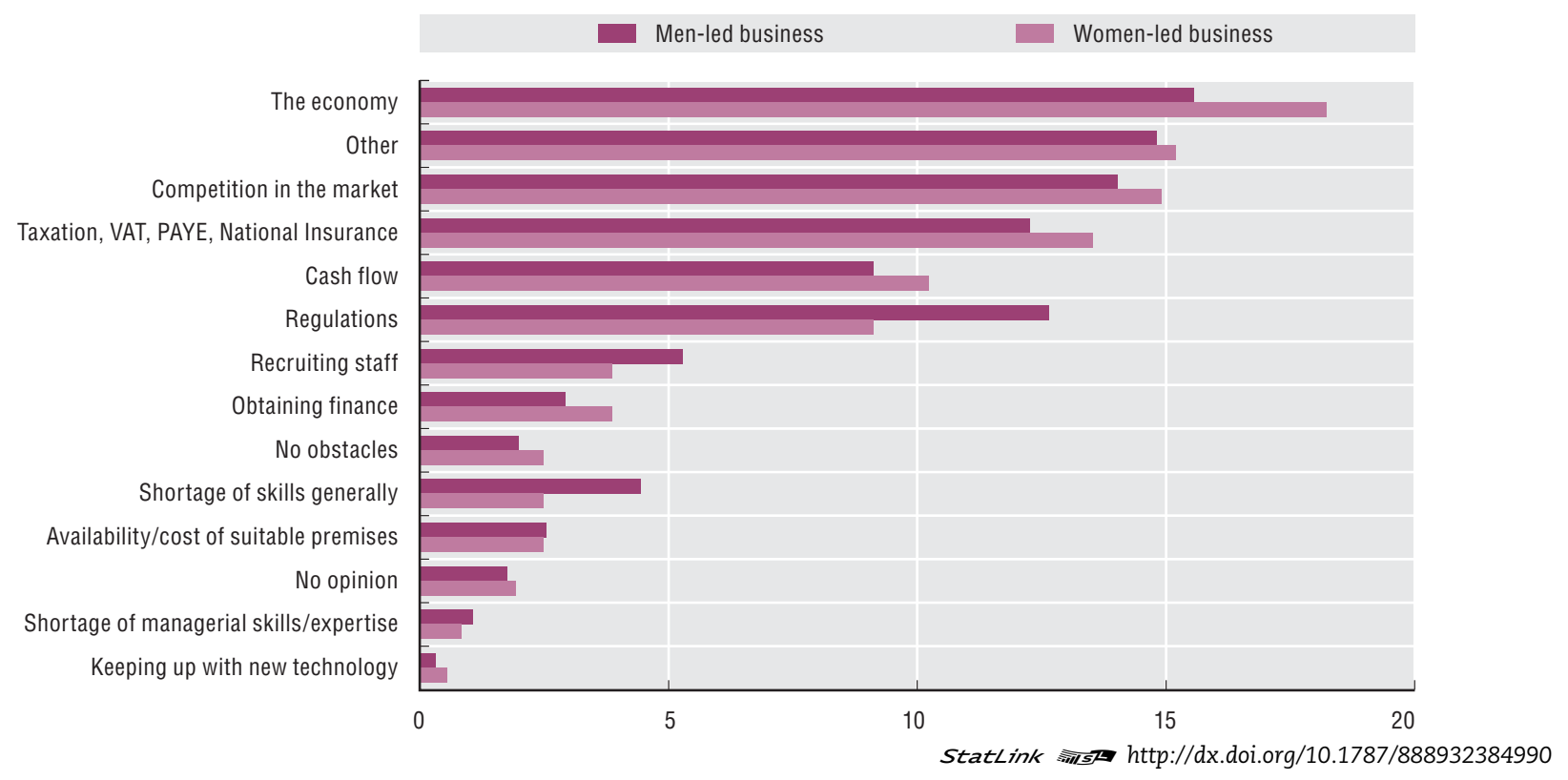



MIGRANT ENTREPRENEURSHIP

19. Share of foreign enterprise owners

ENTREPRENEURSHIP AT A GLANCE 2011 ○ OECD 2011

95 
Foreign migrants often pursue entrepreneurial activities in their country of residence. These can include many types of firms: from ones which employ only a few workers and have limited growth potential to firms that grow quickly, creating many new jobs and everything in between. How these firms may fare and provide for migrants varies across countries and their regulatory framework. It is thus important to understand how successful these firms are, the challenges they may face and what scope exists for policy makers to contribute to their success.

\section{Definitions}

\section{Self-employed}

Self-employed persons are defined as those who work in their own business, professional practice or farm for the purpose of earning a profit. They may or may not have employees.

A country's foreign-born population includes all persons who have that country as their usual residence and who were born in another country.

\section{Start-ups and closures by foreign-born business owners}

The indicator measures the start-ups and closures by foreign business owners as a share of the total startups and closures in Germany.

\section{Business ownership by migrants}

Business ownership by migrants is expressed as a percentage of respectively the number of active enterprises and the number of foreign residents in Italy.

Until recently, research on entrepreneurship has typically used self-employment as a measure for entrepreneurship; it is the widespread availability of data on self-employment that has encouraged their use in the context of the analysis of entrepreneurship. It is important to remind that the EIP has departed from this standard approach by focusing on business data rather than data on individuals, acknowledging that entrepreneurial activity cannot be represented only by business owners as it can also occur in existing businesses.

\section{Comparability}

Data on self-employed persons, from Labour Force Surveys, refer to 2008, with the exception of Poland, Sweden and Turkey (2007) and Australia (2006).

Data for Germany and Italy are presented as examples of business data describing the phenomenon of entrepreneurship by migrants. The choice of these two countries is due to data availability.

\section{Highlights}

In a majority of countries, self-employment is higher for the population of foreign-born than for the population of native-born. It is however difficult to assert that this implies a higher propensity to entrepreneurship by migrants as compared to natives.

The share of start-ups and closures by foreign-born owners over the total start-ups and closures has continuously progressed in Germany in recent years.

Entrepreneurship by migrants is non-negligible in Italy, where regional differences in the prevalence of business ownership by foreign born persons can be observed.

\section{Sources}

OECD, International Migration Outlook: SOPEMI 2010.

Federal Statistical Office of Germany: Business Notification Statistics, Wiesbaden 2009; Calculations of IfM Bonn.

Dossier Statistico Immigrazione Caritas/MigrantesEthnoland. Elaborazioni su dati Istat, Infocamere e Cna.

\section{For further reading}

OECD (2010), "Entrepreneurship and Migrants", Report by the OECD Working Party on SMEs and Entrepreneurship, OECD. www.oecd.org/dataoecd/34/18/45068866.pdf 
Figure 19.1. Self-employed by place of birth, 15-to-64-year-olds, 2008

As a percentage of total employment

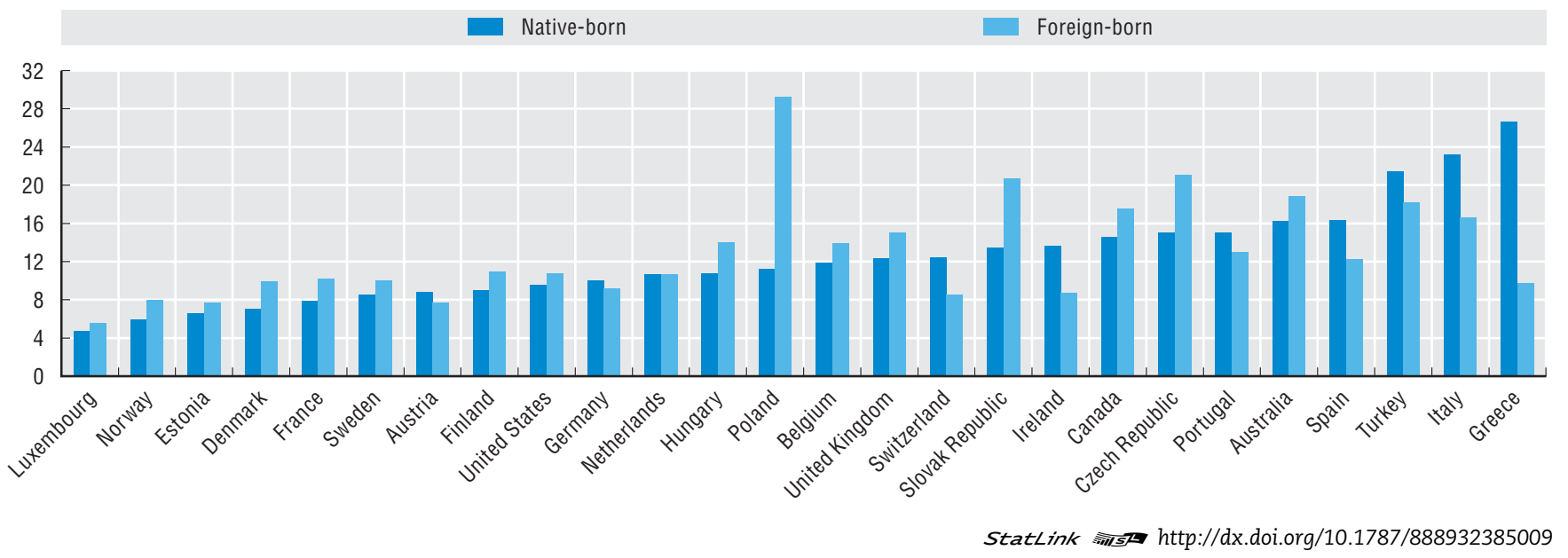

Figure 19.2. Start-ups and closures by foreign-born business owners, Germany, 2005-2008 As a percentage of total start-ups and closures

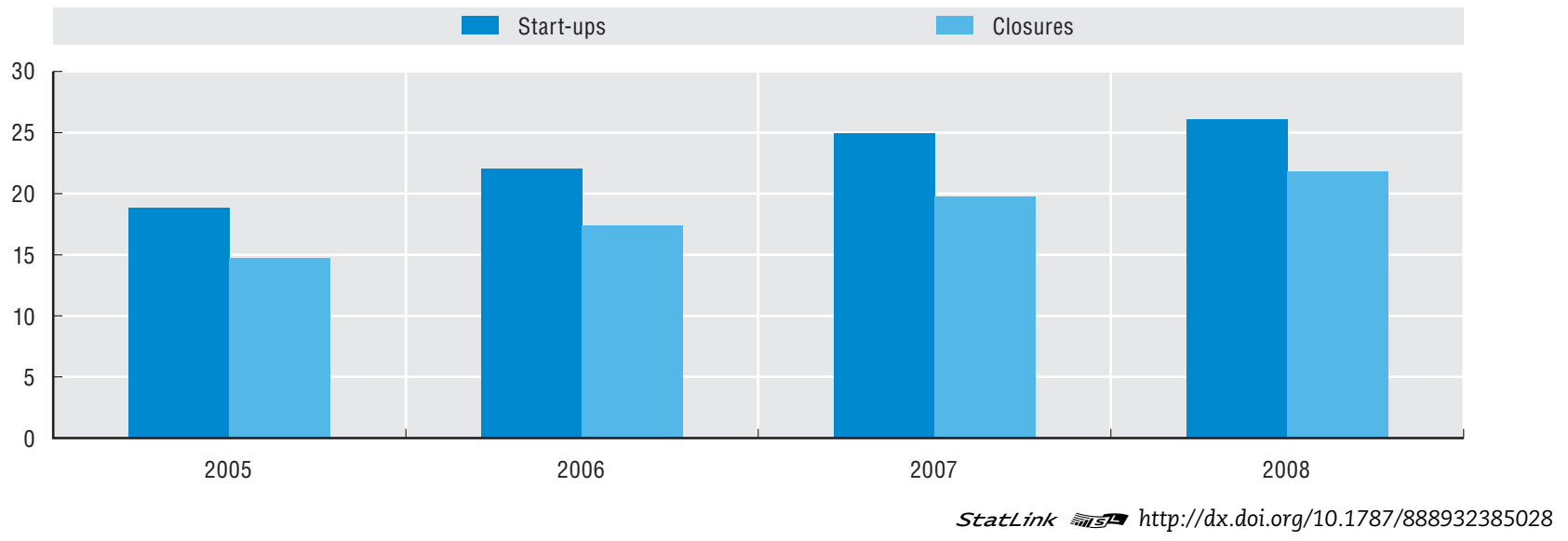

Figure 19.3. Business ownership by migrants, Italy, 2008

As a percentage of the total number of active enterprises and total number of foreign residents

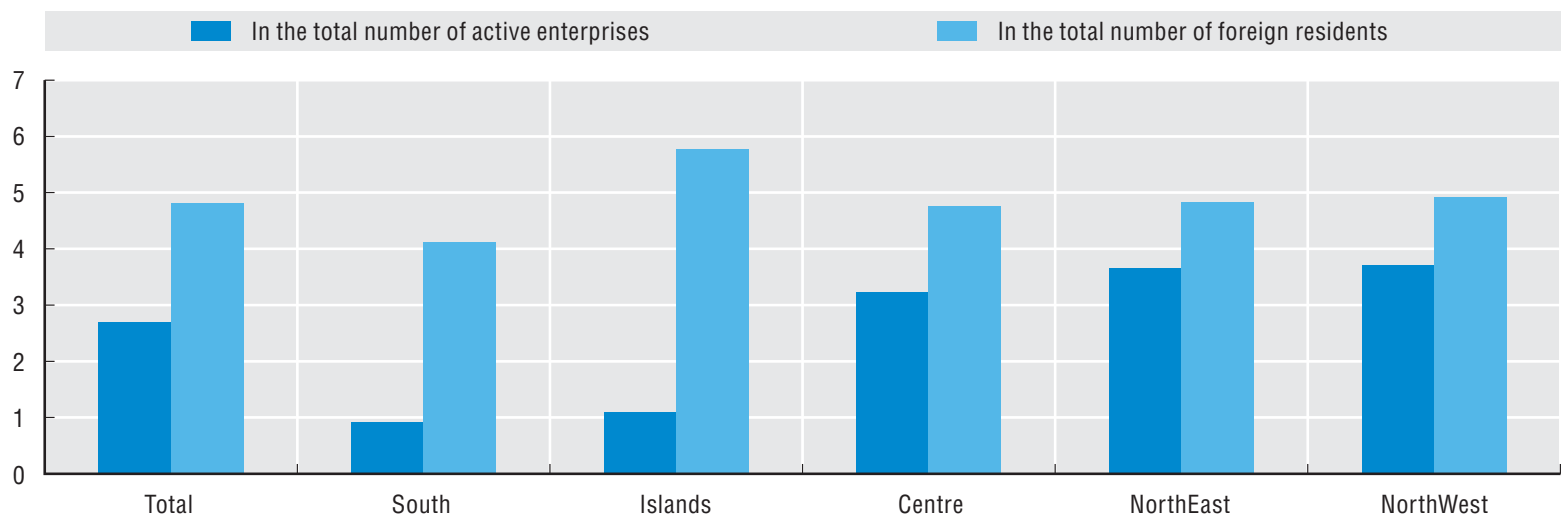

StatLink तiाsय $h$ ttp://dx.doi.org/10.1787/888932385047 



\section{DETERMINANTS OF ENTREPRENEURSHIP: SELECTED INDICATORS}

20. Regulatory framework: Starting a business

21. Access finance: Venture capital

22. Culture: The image of entrepreneurs 
A combination of opportunity, capabilities and resources does not necessarily lead to entrepreneurship if opportunity costs (e.g. forgone salary and loss of health insurance) and start-up costs outweigh the potential benefits. The regulatory framework is therefore a critical factor affecting countries' entrepreneurial performance. While the regulatory framework, as broadly defined by the EIP, encompasses taxes, regulations and other public rules and institutions affecting entrepreneurship, this section focuses on measures of burden on the creation of new enterprises.

\section{Definitions}

The indicator administrative burdens on start-ups measures the burdens of creating a new entreprise. It is a composite indicator resulting from the aggregation of three low level indicators: administrative burdens for corporations, administrative burdens for sole proprietor firms, and sector-specific administrative burdens.

The indicator starting a business is a composite indicator measuring the procedures, time and costs necessary to incorporate and register a new firm with up to 50 employees and start-up capital of 10 times the economy's per-capita gross national income.
Data refer to 2008; for Greece, Ireland, and Slovak Republic they refer to 2003 and for India, Indonesia and South Africa to 2007.

\section{Starting a business}

Data are drawn from the World Bank's Doing Business report. This is an annual publication based on a survey of domestic laws, regulations and administrative requirements. It provides quantitative measures of regulations that apply to domestic small and medium-size enterprises in a number of areas, namely: starting a business, dealing with construction permits, registering property, getting credit, protecting investors, paying taxes, trading across borders, enforcing contracts; closing a business, employing workers and getting electricity. The construction of the indicators is based on the assumption that the business is located in the largest business city of the economy.

The most recent data collection was done in 2010 .

\section{Highlights}

While differently built, the two measures of the administrative burdens of starting a business show a good correlation, i.e. both of them indicate more favourable conditions in English-speaking countries and Nordic European countries.

\section{Sources/Online databases}

OECD Indicators of Product Market Regulation. www.oecd.org/document/36/ 0,3746,en_2649_34323_35790244_1_1_1_1,00.html

World Bank Doing Business Database. www.doingbusiness.org/data

\section{For further readings}

Wölfl, A., I. Wanner, T. Kozluk, G. Nicoletti (2009), Ten Years of Product Market Reform in OECD Countries - Insights From a Revised PMR Indicator. www.oecd.org/dataoecd/29/41/42779045.pdf

World Bank, 2011 Doing Business Report. www.doingbusiness.org/ /media/FPDKM/Doing\%20Business/ Documents/Annual-Reports/English/DB11-FullReport.pdf

Information on data for Israel:

http://dx.doi.org/10.1787/888932315602 


\section{DETERMINANTS OF ENTREPRENEURSHIP: SELECTED INDICATORS}

Figure 20.1. Administrative burdens on start-ups, 2008

Scale from 0 to 6 from least to most restrictive

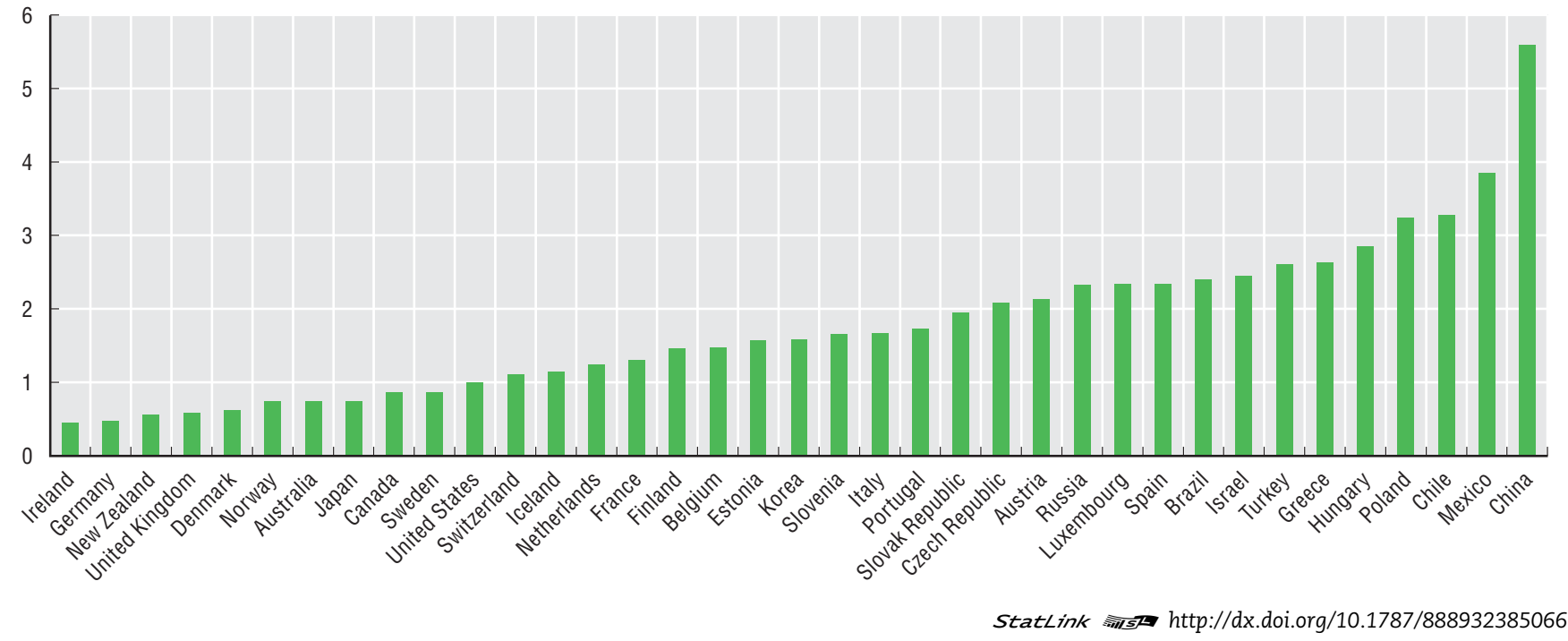

Figure 20.2. Starting a business, 2010

Ranking of countries from least to more restrictive

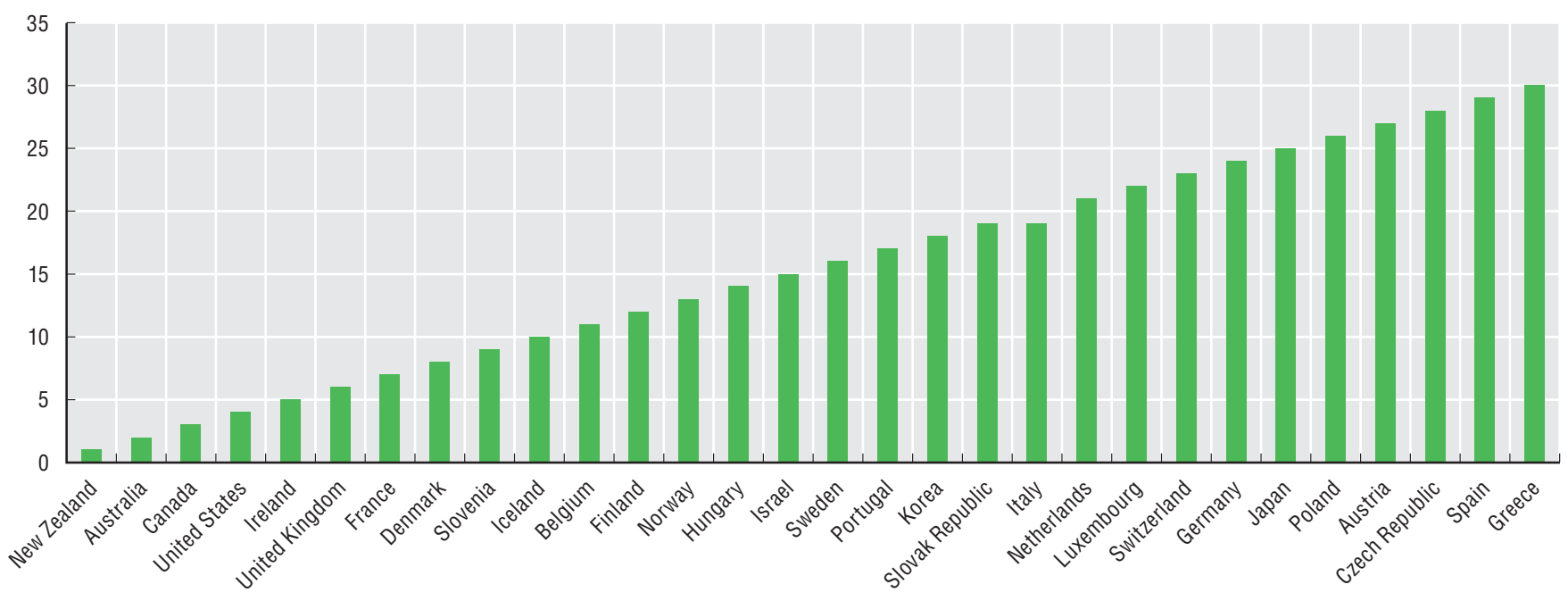

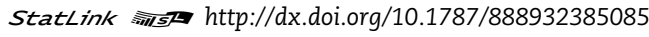


Venture capital is a type of financing that has an important role for young companies with innovation and growth potential, as it replaces or complements traditional bank financing. The development of the venture capital industry is seen by policy makers as an important framework condition to stimulate entrepreneurship.

\section{Definition}

Venture capital is capital provided to young, unquoted firms with high growth potential.

Venture capital investment as percentage of GDP measures the sum of seed and start-up capital and early development capital as a share of a country's GDP.

\section{Comparability}

Data on venture capital are drawn mainly from national or regional venture capital associations; in a few cases, the sources are international providers of business data. All figures presented by the different sources are nominal figures.

Venture capital is defined as the sum of seed and start-up capital and early development capital. As there are no harmonised definitions of venture capital stages across venture capital associations and other data providers, the original data have been re-aggregated according to a harmonisation table developed for the Entrepreneurship Financing Database of the EIP. In particular, seed/start-up/ other early stage includes pre-seed stage for Australia. The other venture capital stage includes: for Australia, early expansion; for European countries, later stage; for the United States, expansion. For European countries, bridge financing have been removed from later stage.

A second figure, Figure 21.2, is proposed where growth capital, defined as capital provided to an established firm that needs financing to support growth, is added to venture capital.

The growth stage includes: for Australia, late expansion; for Canada, expansion; for European countries, growth; for the United States, later stage.

Readers should be aware that in the field of venture capital measurement, the margin for improving the methodologies for national and internationally comparable data collection is still important.

\section{Highlights}

Venture capital, defined as the sum of seed/start-up capital and early development capital, still represents a minimal percentage of GDP, which in most countries is less than $0,05 \%$. Countries with a more developed venture capital market include Israel, Sweden, Switzerland, the United Kingdom and the United States.

\section{Source}

OECD Entrepreneurship Financing Database, built from:

- ABS: Australia.

- EVCA: Austria, Belgium, Czech Republic, Denmark, Estonia, Finland, France, Germany, Greece, Hungary, Ireland, Italy, Luxembourg, the Netherlands, Norway, Poland, Portugal, Slovenia, Spain, Sweden, Switzerland, United Kingdom.

- KVCA: Korea.

- NZVCA: New Zealand.

- PwC MoneyTree: Israel, United States.

- Thomson Reuters: Canada.

Information on data for Israel:

http://dx.doi.org/10.1787/888932315602 


\section{DETERMINANTS OF ENTREPRENEURSHIP: SELECTED INDICATORS}

Figure 21.1. Venture capital as a percentage of GDP, 2009

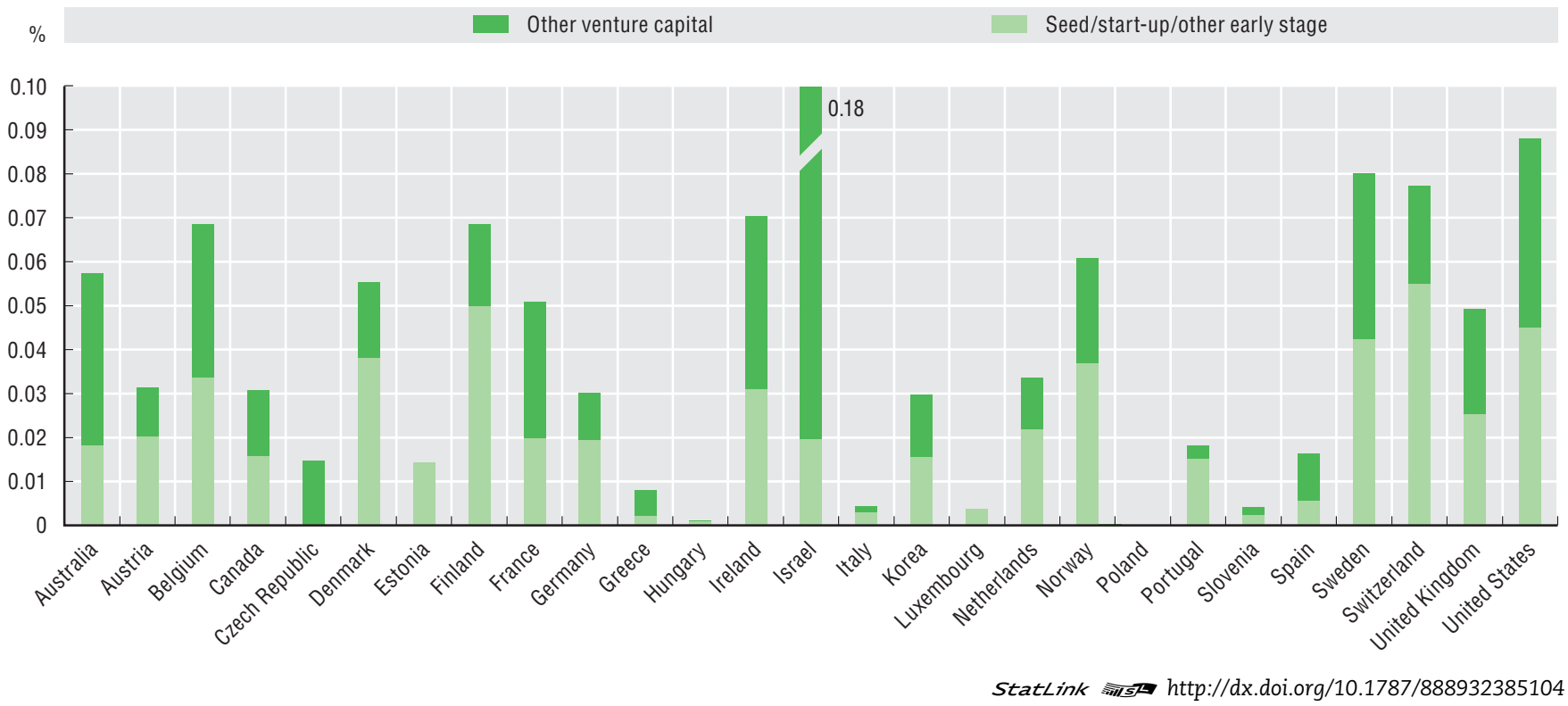

Figure 21.2. Venture capital and growth capital as a percentage of GDP, 2009

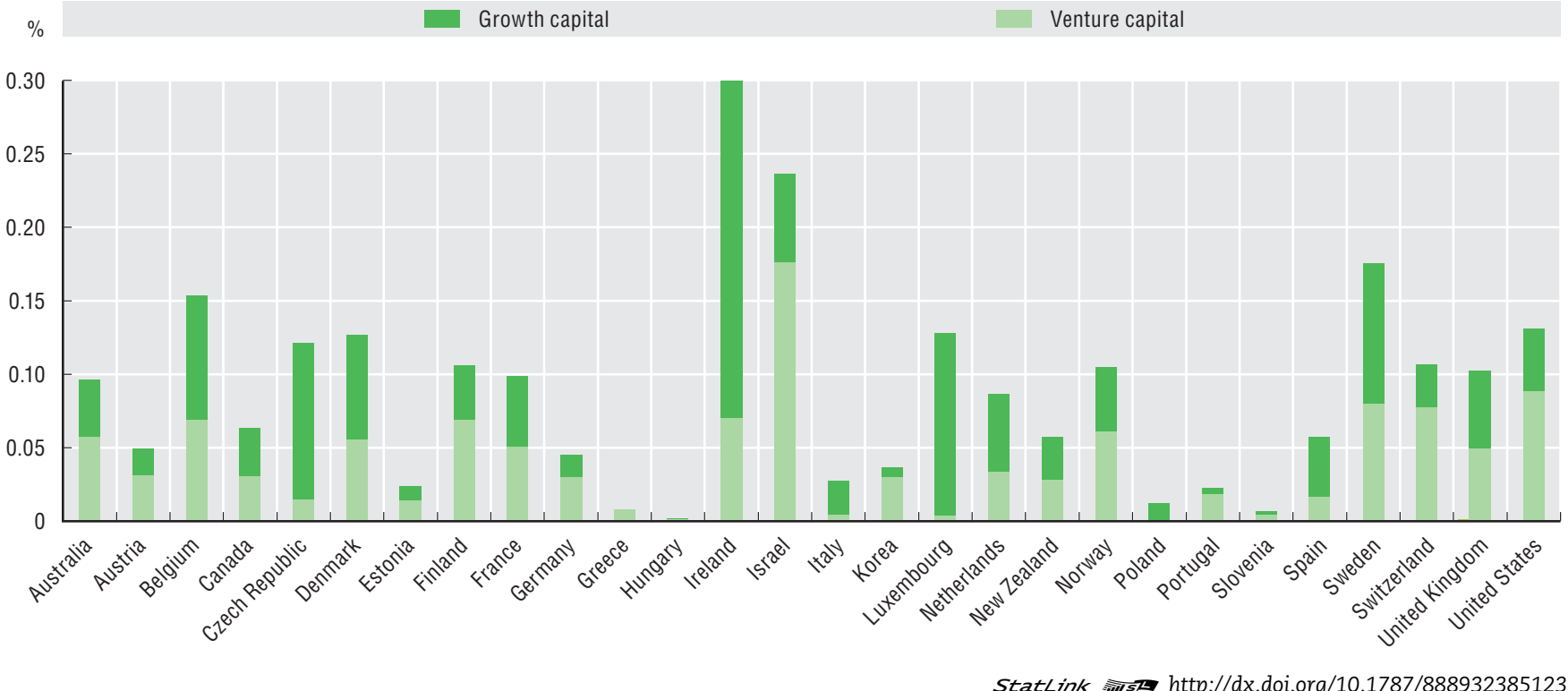


The entrepreneurial culture in a country affects the attitude that individuals have towards entrepreneurship, the likelihood of choosing entrepreneurship as a career, the ambitions to succeed and to start again after a failure, or the support provided to family and relatives planning to set up a business. All these aspects play a role, although there is scarce empirical evidence on their relative importance and differences across countries. This section provides examples of indicators that measure certain aspects of the entrepreneurial culture, in particular the image that people have of entrepreneurs and the understanding of entrepreneurs' role in the economy.

\section{Definitions}

The indicators for the image of entrepreneurs correspond to the following two questions:

- "What is your opinion about entrepreneurs (selfemployed, business owners)", where respondents choose among rather favourable, neutral or rather unfavourable; and

- "My school education helped me to better understand the role of entrepreneurs in society", where respondents indicate whether they strongly agree, agree, disagree or strongly disagree with the statement.

\section{Comparability}

Data are drawn from the Flash Eurobarometer on Entrepreneurship, which is a general survey of adult population conducted periodically for the European Commission Directorate-General Enterprise and Industry. The survey is meant to gather information about peoples' entrepreneurial mindset and gain insights on how these differ across countries. It examines the motivation, choices, experiences and obstacles linked to entrepreneurship; the survey con- siders self-employed and business owners as entrepreneurs.

The 2010 survey covered 36 countries: the EU27, China, Croatia, Iceland, Japan, Korea, Norway, Switzerland, Turkey and the United States. The size of the target sample was of 500 or 1000 individuals depending on the country (except for China). Each national sample is representative of the population aged 15 years and above. In China, interviews were conducted with randomly selected individuals (aged 15 and over) in 50 cities; this sample covered 115000000 of the 615000000 urban inhabitants - and accurately represented the total urban population.

Interviews were conducted between the 10/12/2009 and the 16/01/2010.

\section{Highlights}

There are significant cross-country differences in the way people perceive entrepreneurs. The highest shares of adults who have a rather favourable image of entrepreneurs are found in a group of Nordic countries and the United States, while in the Eastern European countries and Asian countries only one person in three or less has a rather positive image of entrepreneurs. The opinions on the role that school had in forming a view on entrepreneurs are also very diverse from one country to the other. Interestingly, the ranking of countries related to the perceived role of school in understanding entrepreneurs presents many differences compared to the ranking based on the share of adults having a favourable image of entrepreneurs.

\section{Source}

European Commission (2010), Flash Eurobarometer Series, No. 283, Entrepreneurship in the EU and beyond. A survey in the EU, EFTA countries, Croatia, Turkey, the US, Japan, South Korea and China. Analytical report. 


\section{DETERMINANTS OF ENTREPRENEURSHIP: SELECTED INDICATORS}

Figure 22.1. Image of entrepreneurs, 2010

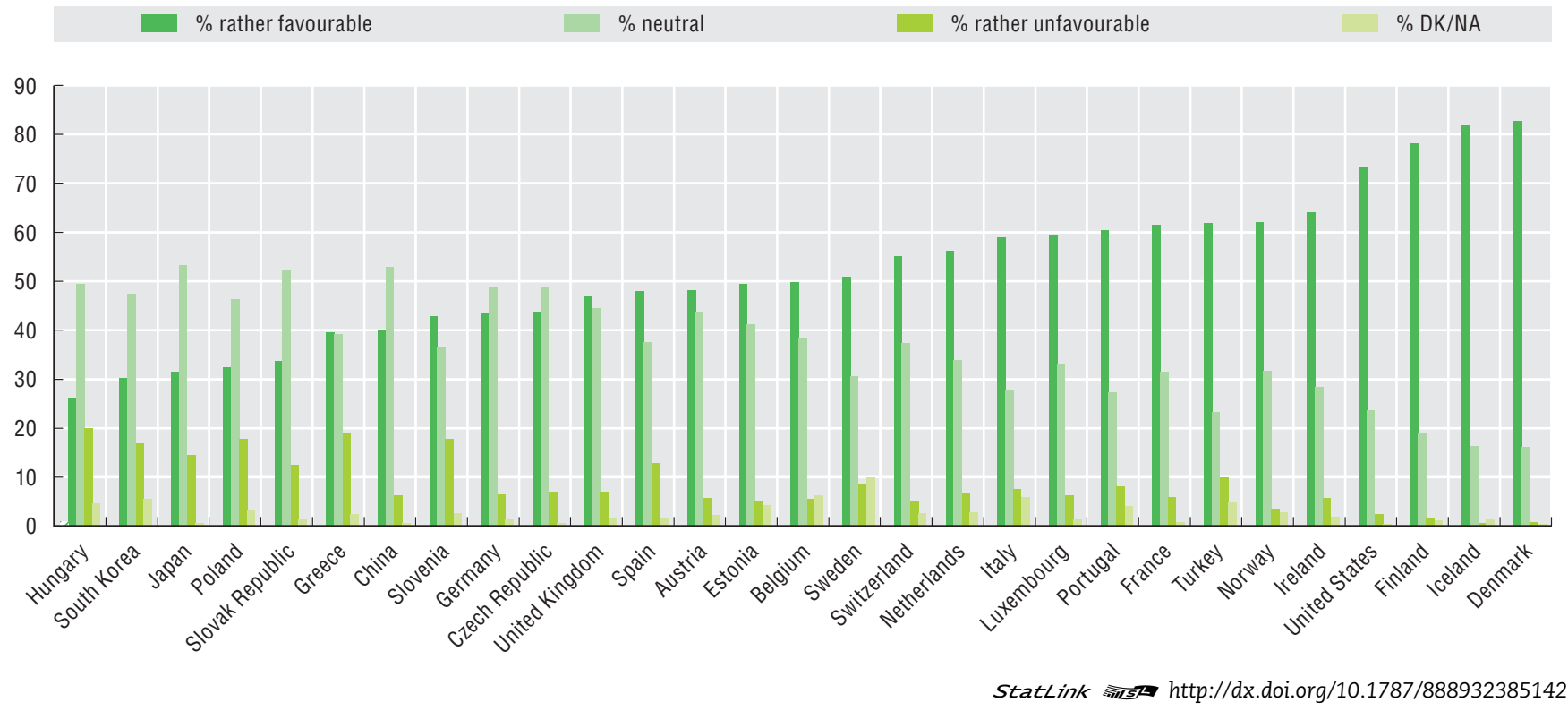

Figure 22.2. School helped in understanding the role of entrepreneurs, 2010

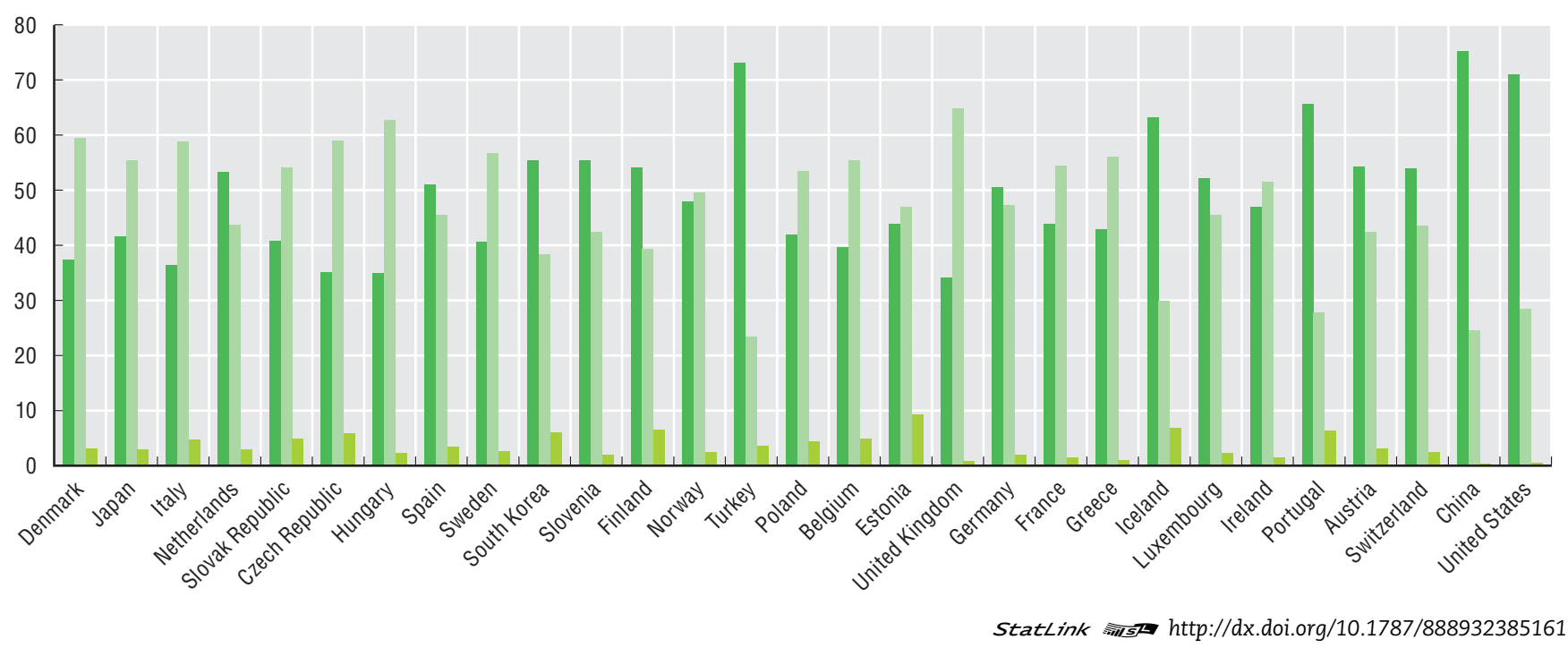





\section{Sources of Data on Timely Indicators of Entrepreneurship}

This Annex presents the sources and definitions used to develop the EIP Timely Indicators of Entrepreneurship; two separate tables refer to enterprise creations and bankruptcies respectively.

\section{Table A.1. National sources and definitions of enterprise creations}

\begin{tabular}{|c|c|}
\hline & Sources and definitions of enterprise creations \\
\hline Australia & $\begin{array}{l}\text { Source: Australian Securities and Investments Commission (ASIC). } \\
\text { New company registrations. } \\
\text { Monthly data. } \\
\text { Incorporated companies only. } \\
\text { www.asic.gov.au/asic/ASIC.NSF/byHeadline/Insolvencies, \%20teminations\%20\&\%20new\%20reg\%20stats\%20portal\%20page }\end{array}$ \\
\hline Austria & $\begin{array}{l}\text { Source: Wirtschaftskammer Österreich (WKO) - The Austrian Federal Economic Chamber. } \\
\text { Annual data. } \\
\text { http://portal.wko.at/wk/format_detail.wk?AngID=1\&St/D=357329\&Dst/D=17 }\end{array}$ \\
\hline Belgium & $\begin{array}{l}\text { Source: SPF Economie, DGSIE, Dynamique de la population des entreprises - assujettissements à la TVA. } \\
\text { Monthly data. } \\
\text { http://statbel.fgov.be/fr/statistiques/chiffres/economie/entreprises/vie_entreprises/assuj/dynamique/index.jsp }\end{array}$ \\
\hline Canada & $\begin{array}{l}\text { Source: Office of the Superintendent of Bankruptcy Canada. } \\
\text { Monthly data. } \\
\text { A business bankruptcy is defined as the state of a business that has made an assignment in bankruptcy or against whom a bankruptcy order has been } \\
\text { made. A business is defined as any commercial entity or organization other than an individual, or an individual who has incurred } 50 \text { percent or more } \\
\text { of total liabilities as a result of operating a business. } \\
\text { http://osb.ic.gc.ca }\end{array}$ \\
\hline Denmark & $\begin{array}{l}\text { Source: The (Danish) Central Business Register (CVR). } \\
\text { Monthly (and quarterly) data. } \\
\text { Number of new registrations (primarily birth enterprises) in "market industries" (exclusive e.g. agriculture). } \\
\text { Entries reflect the appearance of new registrations of births, mergers, renaming, split-off, etc. All kinds of enterprises are included (incorporated, sole } \\
\text { proprietors, corporations, etc.). } \\
\text { www.cvr.dk/Site/Forms/CMS/DisplayPage.aspx?pageid=21 }\end{array}$ \\
\hline Finland & $\begin{array}{l}\text { Source: Statistics Finland. } \\
\text { Quarterly data. } \\
\text { These statistics are derived from data in Statistics Finland's Business Register. They cover those enterprises engaged in business activity that are liable } \\
\text { to pay value-added tax or act as employers. Excluded are foundations, housing companies, voluntary associations, public authorities and religious } \\
\text { communities. The statistics cover enterprises of the state but not those of municipalities. Data are provided for the number of enterprise "openings". } \\
\text { http://pxweb2.stat.fi/Database/StatFin/Yri/aly/aly_fi.asp }\end{array}$ \\
\hline France & $\begin{array}{l}\text { Source: INSEE, sirene. } \\
\text { Monthly data. } \\
\text { Number of births. Data are based on the Eurostat definition. A birth amounts to the creation of a combination of production factors with the restriction } \\
\text { that no other enterprises are involved in the event. } \\
\text { Data exclude registrations of self-employed in order to mitigate the bias due to the implementation in } 2009 \text { of a new enterprise status } \\
\text { (régime de l'autoentrepreneur). } \\
\text { Excluding data on agriculture. } \\
\text { www.insee.fr/fr/themes/indicateur.asp?id=41 }\end{array}$ \\
\hline
\end{tabular}


Table A.1. National sources and definitions of enterprise creations (cont.)

\begin{tabular}{|c|c|}
\hline & Sources and definitions of enterprise creations \\
\hline Germany & $\begin{array}{l}\text { Source: Statistiches Bundesamt - Destatis - Unternehmen und Arbeitsstätten, Gewerbeanzeigen. } \\
\text { Monthly data. } \\
\text { Number of new establishments (main offices and secondary establishments). Small units and auxiliary activities are not included. Transformation, } \\
\text { take-over and change in ownership are excluded. New enterprises coming from abroad are also removed from the data on birth. } \\
\text { All activities are taken into account. } \\
\text { https://www-ec.destatis.de/csp/shop/sfg/bpm.html.cms.cBroker.cls?cmspath=struktur,n0000.csp\&treeid=52000 }\end{array}$ \\
\hline Hungary & $\begin{array}{l}\text { Source: Hungarian Central Statistical Office }(\mathrm{HCSO} / \mathrm{KSH}) \text {. } \\
\text { Quarterly data. } \\
\text { Number of newly registered economic corporations and unincorporated enterprises. } \\
\text { In 2008, sole proprietors engaged in agriculture activities must register as entrepreneurs. } \\
\text { http://portal.ksh.hu/portal/page?_pageid=38,600544\&_dad=portal\&_schema=PORTAL }\end{array}$ \\
\hline Iceland & $\begin{array}{l}\text { Source: Statistics Iceland. } \\
\text { Monthly data. } \\
\text { New registrations of limited liability companies. } \\
\text { All activities are taken into account. } \\
\text { WWw.statice.is/Statistics/Enterprises-and-turnover/Enterprises }\end{array}$ \\
\hline Italy & $\begin{array}{l}\text { Source: InfoCamere, Movimprese - Registre d'entreprises des chambres de commerce italiennes. } \\
\text { Quarterly data. } \\
\text { Number of entries (iscritte). } \\
\text { All legal forms and all activities are taken into accounts. } \\
\text { www.infocamere.it/movimprese.htm }\end{array}$ \\
\hline Netherlands & $\begin{array}{l}\text { Source: Centraal Bureau voor de Statistiek (CBS) - Registre d'entreprises. } \\
\text { Quarterly data. } \\
\text { Number of establishment births (i.e. excluding mergers, take-over, change of name, change of legal form, change of ownership, gradual change of } \\
\text { activities, nationalization). } \\
\text { Data are only available for Industry, trade and market services. Items A,B,E,J,K70,K73,L,M,N,091,092 are excluded. } \\
\text { www.cbs.nl/nl-NL/menu/themas/bedrijven/cijfers/default.htm }\end{array}$ \\
\hline Norway & $\begin{array}{l}\text { Source: Statistics Norway. } \\
\text { Quarterly data. } \\
\text { Number of newly established enterprises. } \\
\text { Excluding primary industries. } \\
\text { http://statbank.ssb.no/statistikkbanken/Default_FR.asp?Productid=10.01\&PXSid=0\&nvl=true\&PLanguage=1\&tilside=selecttable/ } \\
\text { MenuSeIP.asp\&SubjectCode=10 }\end{array}$ \\
\hline Portugal & $\begin{array}{l}\text { Source: Formation and dissolution of companies, Ministry of Justice. } \\
\text { Incorporated companies only. }\end{array}$ \\
\hline Spain (Monthly) & $\begin{array}{l}\text { Source: Instituto Nacional de Estadistica de Espana (INE) - The Mercantile Companies (MC). } \\
\text { Monthly data. } \\
\text { The "Mercantile Companies" register includes information on incorporated enterprises (natural persons or sole proprietors are excluded). "Created } \\
\text { mercantile companies" may not be active and "dissolved mercantile companies" might be removed from the register without having ever been active. } \\
\text { www.ine.es/jaxi/menu.do?type=pcaxis\&path=\%2Ft30\%2Fp151\&file=inebase\&L=1 }\end{array}$ \\
\hline Spain (Annual) & $\begin{array}{l}\text { Source: Companies Central Directory (CCD). } \\
\text { Number of entries }\end{array}$ \\
\hline Sweden & $\begin{array}{l}\text { Source: Swedish Agency for Growth Analysis. } \\
\text { Quarterly data. } \\
\text { Number of new enterprises (genuine new businesses i.e. births). } \\
\text { www.tillvaxtanalys.se/sv/statistik/ }\end{array}$ \\
\hline United Kingdom & $\begin{array}{l}\text { Source: Companies House. } \\
\text { Quarterly data. } \\
\text { New registrations (number of entries). } \\
\text { All limited companies in England, Wales, Northern Ireland and Scotland are registered at Companies House. } \\
\text { Entries reflect the appearance of a new enterprise within the economy, whatever the demographic event, be that a merger, renaming, split-off... or birth } \\
\text { www.companieshouse.gov.uk/about/companiesRegActivities.shtmI }\end{array}$ \\
\hline United States & $\begin{array}{l}\text { Source: Bureau of Labor Statistics (BLS) - Business Employment Dynamics (BED). } \\
\text { Unemployment insurance (UI) records. } \\
\text { Quarterly data. } \\
\text { Number of establishments with at least one employee. } \\
\text { Number of Openings: These are either units with positive third month employment for the first time in the current quarter, with no links to the prior } \\
\text { quarter, or with positive third month employment in the current quarter following zero employment in the previous quarter. } \\
\text { Major exclusions from UI coverage are self-employed workers, religious organisations, most agricultural workers on small farms, all members of the } \\
\text { Armed Forces, elected officials in most States, most employees of railroads, some domestic workers, most student workers at schools, and employees } \\
\text { of certain nonprofit organisations. } \\
\text { www.bls.gov/bdm/ }\end{array}$ \\
\hline
\end{tabular}




\section{Table A.2. National sources and definitions of bankcruptcies}

\begin{tabular}{|c|c|}
\hline Countries & Sources and definitions of bankruptcies \\
\hline Australia & $\begin{array}{l}\text { Source: Australian Securities and Investments Commission (ASIC). } \\
\text { Monthly data. } \\
\text { Insolvency statistics - Companies entering external administration. } \\
\text { The statistics on "Companies entering external administration" show the number of companies entering into a form of external administration for the } \\
\text { first time. ASIC advises that a company will be included only once in these statistics, regardless of whether it subsequently enters into another form } \\
\text { of external administration. The only exception occurs where a company is taken out of external administration, for example as the result of a court } \\
\text { order, and at a later date re-enters external administration. Members voluntary windings up are excluded. } \\
\text { Provisional data. } \\
\text { www.asic.gov.au/asic/ASIC.NSF/byHeadline/Insolvencies,\%20teminations\%20\&\%20new\%20reg\%20stats\%20portal\%20page }\end{array}$ \\
\hline Canada & $\begin{array}{l}\text { Source: Office of the Superintendent of Bankruptcy Canada. } \\
\text { Monthly data. } \\
\text { A business bankruptcy is defined as the state of a business that has made an assignment in bankruptcy or against whom a bankruptcy order has been } \\
\text { made. A business is defined as any commercial entity or organization other than an individual, or an individual who has incurred } 50 \text { percent or more of } \\
\text { total liabilities as a result of operating a business. } \\
\text { http://osb.ic.gc.ca }\end{array}$ \\
\hline Denmark & $\begin{array}{l}\text { Source: The Danish Official Gazette (Statstidende) and the Statistical Business Register. Statistics Denmark. } \\
\text { Registry-based method from January } 2009 \text { onwards, "simple count" method before. The number of announcements of bankruptcies is counted } \\
\text { excluding units from the Faroe Islands and Greenland. When using the "simple count method", bankruptcies of both enterprises and individuals } \\
\text { (personal bankruptcies) were counted. After the implementation of the registry-based method, only bankruptcies of enterprises are counted, i.e. } \\
\text { bankruptcies associated with a "CVR"-number. } \\
\text { www.dst.dk/HomeUK/Statistics/Key_indicators/generel/Bankruptcies.aspx }\end{array}$ \\
\hline France & $\begin{array}{l}\text { Source: BODACC, data processed by INSEE. } \\
\text { Monthly data. } \\
\text { Business failures. } \\
\text { A business failure is defined as the opening of insolvency proceedings. Liquidations which are the results of a business failure represent only a small } \\
\text { part of the total number of deaths. The statistics on business failures cover both the opening of insolvency proceedings and direct liquidations. They } \\
\text { do not reflect the outcome of the proceedings: continuation, take-over or liquidation. } \\
\text { www.insee.fr/en/themes/indicateur.asp?id=71 }\end{array}$ \\
\hline Iceland & $\begin{array}{l}\text { Source: Statistics Iceland. } \\
\text { Monthly data. } \\
\text { Insolvencies of Icelandic enterprises by field of activity, including personal bankruptcies. } \\
\text { www.statice.is/Statistics/Enterprises-and-turnover/Enterprises }\end{array}$ \\
\hline Netherlands & $\begin{array}{l}\text { Source: Centraal Bureau voor de Statistiek (CBS) - Quarterly data. } \\
\text { Number of bankruptcies pronounced by Dutch courts. } \\
\text { Excluding individuals without a sole proprietorship. } \\
\text { www.cbs.nl/en-GB/menu/themas/bedrijven/cijfers/default.htm?Languageswitch=on }\end{array}$ \\
\hline Norway & $\begin{array}{l}\text { Source: Statistics Norway. } \\
\text { Bankruptcy proceedings including personal bankruptcies. } \\
\text { Monthly data. } \\
\text { www.ssb.no/konkurs_en/ }\end{array}$ \\
\hline United Kingdom & $\begin{array}{l}\text { Source: Companies House. } \\
\text { Quarterly data. } \\
\text { Incorporated companies only. } \\
\text { Total insolvencies. Including compulsory liquidations, creditors' voluntary liquidations, and administrative orders converted to Cred. Excluding } \\
\text { Members' voluntary liquidations. } \\
\text { www.companieshouse.gov.uk/about/companiesRegActivities.shtml }\end{array}$ \\
\hline United States & $\begin{array}{l}\text { United States Courts. } \\
\text { Quarterly data. } \\
\text { Statistics on bankruptcy petition filings - total business filings (Chapters 7, 11, } 12 \text { and 13). } \\
\text { www.uscourts.gov/Statistics/BankruptcyStatistics.aspx }\end{array}$ \\
\hline
\end{tabular}




\section{ANNEX II.B}

\section{List of Indicators of Entrepreneurial Determinants}

This Annex presents a comprehensive list of indicators of entrepreneurial determinants. The list is drawn from the report "Quality Assessment of Entrepreneurship Indicators, Version 5", prepared by FORA (Denmark). Indicators are classified into the six categories of determinants set by the EIP: 1. Regulatory Framework; 2. Market Conditions; 3. Access to Finance; 4; Creation and Diffusion of Knowledge; 5. Entrepreneurial Capabilities; 6. Entrepreneurial Culture. For each indicator, a short description and the source of data are provided.

While many critical factors affecting entrepreneurship are covered by the indicators presented in the table, the list should not be considered as exhaustive. On the one side, the selection of indicators reflects the current availability of data, meaning that important indicators may be missing, for instance in the determinant area "access to finance", just because no source of international data was found. On the other side, research on entrepreneurship is still young, especially on topics such as the relationship between culture and entrepreneurship, with the result that appropriate indicators are yet to be identified.

Table B.1. Indicators of entrepreneurial determinants and data sources

\begin{tabular}{|c|c|c|}
\hline Category of determinants & Definition & Data sources \\
\hline \multicolumn{3}{|c|}{ 1. REGULATORY FRAMEWORK } \\
\hline \multicolumn{3}{|l|}{ Administrative burdens (entry and growth) } \\
\hline Burden of Government Regulation & $\begin{array}{l}\text { Survey responses to the question: Complying with administrative requirements } \\
\text { (permits, regulations, reporting) issued by the government in your country is } \\
\text { ( } 1=\text { burdensome, } 7=\text { not burdensome). }\end{array}$ & $\begin{array}{l}\text { World Economic Forum, } \\
\text { Global Competitiveness Report }\end{array}$ \\
\hline Costs Required for Starting a Business & $\begin{array}{l}\text { The official cost of each procedure in percentage of Gross National Income (GNI) } \\
\text { per capita based on formal legislation and standard assumptions about business and } \\
\text { procedure. }\end{array}$ & World Bank, Doing Business \\
\hline $\begin{array}{l}\text { Minimum Capital Required for Starting a } \\
\text { Business }\end{array}$ & $\begin{array}{l}\text { The paid-in minimum of capital requirement that the entrepreneur needs to deposit } \\
\text { in a bank before registration of the business starts. }\end{array}$ & World Bank, Doing Business \\
\hline Number of Days for Starting a Business & The average time spent during each enterprise start-up procedure. & World Bank, Doing Business \\
\hline $\begin{array}{l}\text { Number of Procedures for Starting a } \\
\text { Business }\end{array}$ & $\begin{array}{l}\text { All generic procedures that are officially required for an entrepreneur to start an industrial } \\
\text { or commercial business. }\end{array}$ & World Bank, Doing Business \\
\hline $\begin{array}{l}\text { Procedures Time and Costs to Build a } \\
\text { Warehouse }\end{array}$ & $\begin{array}{l}\text { Corresponds to an average of three measurements: 1) Average time spent during each } \\
\text { procedure, 2) Official cost of each procedure and 3) Number of procedures to build } \\
\text { a warehouse. }\end{array}$ & World Bank, Doing Business \\
\hline Registering Property & $\begin{array}{l}\text { Corresponds to an average of three measurements: 1) Number of procedures legally } \\
\text { required to register property, 2) Time spent in completing the procedures } \\
\text { and 3) Registering property costs. }\end{array}$ & World Bank, Doing Business \\
\hline $\begin{array}{l}\text { Time it Takes to Prepare, File and Pay the } \\
\text { Corporate Income Tax, VAT and Social } \\
\text { Contributions }\end{array}$ & Time is measured in hours per year. & World Bank, Doing Business \\
\hline
\end{tabular}


Table B.1. Indicators of entrepreneurial determinants and data sources (cont.)

\begin{tabular}{|c|c|c|}
\hline Category of determinants & Definition & Data sources \\
\hline \multicolumn{3}{|l|}{ Bankruptcy Regulations } \\
\hline Actual Cost to Close a Business & The cost is measured in per cent of estate, based on a standard business closure. & World Bank, Doing Business \\
\hline Actual Time to Close a Business & Time is recorded in calendar years. The indicator is based on a standard business closure. & World Bank, Doing Business \\
\hline Bankruptcy Recovery Rate & $\begin{array}{l}\text { The recovery rate estimates how many cents on the dollar claimants - creditors, tax } \\
\text { authorities and employees - recover from an insolvent firm. }\end{array}$ & World Bank, Doing Business \\
\hline Possibility of a Fresh Start & $\begin{array}{l}\text { The indicator measures an entrepreneur's possibility to resume running a business after } \\
\text { experiencing financial difficulties. A fresh start can be attained through a restructuring } \\
\text { of the existing business to avoid bankruptcy or by restructuring debt. }\end{array}$ & $\begin{array}{l}\text { OECD one-off survey "Policy questionnaire } \\
\text { on bankruptcy" }\end{array}$ \\
\hline \multicolumn{3}{|c|}{ Product and Labour Market Regulations } \\
\hline Difficulty of Firing & $\begin{array}{l}\text { The index measures whether laws or other regulations have implications for the difficulties } \\
\text { of firing a standard worker in a standard company, based on fact-based (yes/no) } \\
\text { questions, remodelled into a 0-100 index. }\end{array}$ & World Bank, Doing Business \\
\hline Difficulty of Hiring & $\begin{array}{l}\text { The index measures whether laws or other regulations have implications for the difficulties } \\
\text { of hiring a standard worker in a standard company, based on fact-based (yes/no) } \\
\text { questions, remodelled into a 0-100 index. }\end{array}$ & World Bank, Doing Business \\
\hline Ease of Hiring Foreign Labour & $\begin{array}{l}\text { Survey responses to the question: Labour regulation in your country } \\
\text { ( } 1 \text { = prevents your company from employing foreign labor, } 7 \text { = does not prevent your } \\
\text { company from employing foreign labor). }\end{array}$ & $\begin{array}{l}\text { World Economic Forum, } \\
\text { Global Competitiveness Report }\end{array}$ \\
\hline Extent of Incentive Compensation & $\begin{array}{l}\text { Survey responses to the question: Cash compensation of management } \\
(1=\text { is based exclusively on salary, } 7=\text { includes bonuses and stock options, representing } \\
\text { a significant portion of overall compensation). }\end{array}$ & $\begin{array}{l}\text { World Economic Forum, } \\
\text { Global Competitiveness Report }\end{array}$ \\
\hline Rigidity of Hours Index & $\begin{array}{l}\text { The indicator is an index with five components: i) whether night work is restricted; } \\
\text { ii) whether weekend work is allowed; iii) whether the work week consists of five and a half } \\
\text { days or more; iv) whether the workday can extend to } 12 \text { hours or more (including } \\
\text { overtime); and } v \text { ) whether the annual paid vacation days are } 21 \text { days or less. }\end{array}$ & World Bank, Doing Business \\
\hline \multicolumn{3}{|c|}{ Court and Legal Framework } \\
\hline Enforcing Contracts - Cost in \% of claim & $\begin{array}{l}\text { Cost is recorded as a percentage of the claim, assumed to be equivalent to } 200 \% \\
\text { of income per capita. No bribes are recorded. Three types of costs are recorded: } \\
\text { court costs, enforcement costs and average attorney fees. }\end{array}$ & World Bank, Doing Business \\
\hline $\begin{array}{l}\text { Enforcing Contracts - Number of } \\
\text { Procedures }\end{array}$ & $\begin{array}{l}\text { A procedure is defined as any interaction between the parties, or between them } \\
\text { and the judge or court officer. This includes steps to file the case, steps for trial } \\
\text { and judgment and steps necessary to enforce the judgment. }\end{array}$ & World Bank, Doing Business \\
\hline Enforcing Contracts - Time & $\begin{array}{l}\text { Time is recorded in calendar days, counted from the moment the plaintiff files the lawsuit } \\
\text { in court until payment. This includes both the days when actions take place and the waiting } \\
\text { periods between. }\end{array}$ & World Bank, Doing Business \\
\hline \multicolumn{3}{|l|}{ Social and Health Security } \\
\hline $\begin{array}{l}\text { Public Expenditure on Unemployment } \\
\text { Support }\end{array}$ & $\begin{array}{l}\text { Public expenditure on unemployment per unemployed in USD, current PPPs. } \\
\text { Public expenditure includes both partly, full public pay and any other program } \\
\text { expenditures the public has. }\end{array}$ & $\begin{array}{l}\text { OECD, Public expenditure and participant } \\
\text { stocks on Labour Market Policy (LMP) }\end{array}$ \\
\hline Public Health Care Coverage & $\begin{array}{l}\text { The share of the population eligible for a defined set of health care goods and services } \\
\text { under public programmes. }\end{array}$ & OECD Health data \\
\hline \multicolumn{3}{|l|}{ Income taxes; Wealth/Bequest Taxes } \\
\hline $\begin{array}{l}\text { Average Income Tax plus Social } \\
\text { Contributions }\end{array}$ & $\begin{array}{l}\text { The average rate of taxation in percentage of the gross wage. The indicator is based } \\
\text { on a standard case: single (without children) with high income. }\end{array}$ & OECD Revenue Statistics \\
\hline $\begin{array}{l}\text { Highest Marginal Income Tax plus Social } \\
\text { Contributions }\end{array}$ & $\begin{array}{l}\text { The highest rate of taxation in percentage of the gross wage. The indicator is based } \\
\text { on a standard case: single (without children) with high income. }\end{array}$ & OECD Revenue Statistics \\
\hline Revenue from Bequest Tax & The revenue from bequest tax as a per cent of GDP on a 3 year moving average. & OECD Revenue Statistics \\
\hline Revenue from Net Wealth Tax & The revenue from net wealth tax as a per cent of GDP on a 3 year moving average. & OECD Revenue Statistics \\
\hline \multicolumn{3}{|l|}{ Business and Capital Taxes } \\
\hline SME Tax Rates & & OECD Revenue Statistics \\
\hline Taxation of Corporate Income Revenue & $\begin{array}{l}\text { The revenue from corporate income tax as percentage of GDP on a three year moving } \\
\text { average. }\end{array}$ & OECD Revenue Statistics \\
\hline $\begin{array}{l}\text { Taxation of Dividends - Top Marginal } \\
\text { Tax Rate }\end{array}$ & & OECD Tax Database \\
\hline Taxation of Stock Options & The average tax wedge for purchased and newly listed stocks. Average incomes are used. & $\begin{array}{l}\text { OECD, The Taxation of Employee Stock } \\
\text { Options - Tax Policy Study No. } 11\end{array}$ \\
\hline \multicolumn{3}{|l|}{ Patent System; Standards } \\
\hline Intellectual Property Rights & $\begin{array}{l}\text { Survey responses to the question: intellectual property protection in the world } \\
\text { ( } 1=\text { is weak or nonexistent, } 7=\text { is equal to the world's most stringent). }\end{array}$ & $\begin{array}{l}\text { World Economic Forum, } \\
\text { Global Competitiveness Report }\end{array}$ \\
\hline Property Rights & $\begin{array}{l}\text { Survey responses to the question: property rights, including over financial assets ( } 1 \text { = are } \\
\text { poorly defined and not protected by law, } 7=\text { are clearly defined and well protected by law). }\end{array}$ & $\begin{array}{l}\text { World Economic Forum, } \\
\text { Global Competitiveness Report }\end{array}$ \\
\hline
\end{tabular}


Table B.1. Indicators of entrepreneurial determinants and data sources (cont.)

\begin{tabular}{|c|c|c|}
\hline Category of determinants & Definition & Data sources \\
\hline \multicolumn{3}{|c|}{ 2. MARKET CONDITIONS } \\
\hline \multicolumn{3}{|l|}{ Anti-trust Laws } \\
\hline Antitrust Framework & $\begin{array}{l}\text { The framework covers scope and enforcement of law and independence of competition } \\
\text { authority and is assessed by a scale from } 0 \text { to } 6 \text {. ( } 0=\text { best score, } 6=\text { the worst score). }\end{array}$ & $\begin{array}{l}\text { OECD, Competition Law and Policy } \\
\text { indicators for OECD Countries }\end{array}$ \\
\hline \multicolumn{3}{|l|}{ Competition } \\
\hline Network Policies & $\begin{array}{l}\text { The indicator covers two areas: } 1 \text { ) the independence of sector regulators; and } 2) \text { access } \\
\text { issues. The independence of sector regulators constitutes elements such as institutional } \\
\text { design, the regulator's sectoral authority and powers plus accountability. Access covers } \\
\text { entry barriers and the degree of vertical integration in the sector. Network policies are } \\
\text { assessed by a scale from } 0 \text { to } 6 \text {. ( } 0 \text { = best score, } 6 \text { = the worst score). }\end{array}$ & $\begin{array}{l}\text { OECD, Competition Law and Policy } \\
\text { indicators for OECD Countries }\end{array}$ \\
\hline \multicolumn{3}{|l|}{ Access to Foreign Markets } \\
\hline Export Burdens & $\begin{array}{l}\text { An average of three measurements: 1) Number of all documents required to export goods, } \\
\text { 2) Number of signatures required to export goods, 3) Time necessary to comply with all } \\
\text { procedures required to export goods. }\end{array}$ & World Bank, Doing Business \\
\hline Import Burdens & $\begin{array}{l}\text { An average of three measurements: 1) Number of all documents required to import goods, } \\
\text { 2) Number of signatures required to import goods, 3) Time necessary to comply with all } \\
\text { procedures required to import goods. }\end{array}$ & World Bank, Doing Business \\
\hline \multicolumn{3}{|l|}{ Degree of Public Involvement } \\
\hline Government Enterprises and Investment & $\begin{array}{l}\text { Data is composed of the number, composition, and share of output supplied } \\
\text { by State-Operated Enterprises (SOEs) and government investment as a share of total } \\
\text { investment. }\end{array}$ & $\begin{array}{l}\text { IMF, World Bank, UN National Accounts and } \\
\text { World Economic Forum }\end{array}$ \\
\hline Licensing Restrictions & $\begin{array}{l}\text { Zero-to-10 ratings are constructed for } 1 \text { ) the time cost (measured in number of calendar } \\
\text { days required to obtain a license) and 2) the monetary cost of obtaining the license } \\
\text { (measured as a share of per-capita income). These two ratings are then averaged } \\
\text { to arrive at the final rating. }\end{array}$ & World Bank \\
\hline Ownership of Banks & $\begin{array}{l}\text { Data on the percentage of bank deposits held in privately owned banks is used } \\
\text { to construct rating intervals of public ownership in the financial sector. }\end{array}$ & World Bank \\
\hline Price Controls & $\begin{array}{l}\text { The indicator measures the extent to which prices are determined by the market or } \\
\text { by government involvement. }\end{array}$ & IMD World Competitiveness Yearbook \\
\hline \multicolumn{3}{|l|}{ Private Demand } \\
\hline Buyer Sophistication & $\begin{array}{l}\text { Survey responses to: purchasing decisions are }(1=\text { based solely on the lowest price, } \\
7 \text { = based on a sophisticated analysis of performance). }\end{array}$ & $\begin{array}{l}\text { World Economic Forum, } \\
\text { Global Competitiveness Report }\end{array}$ \\
\hline \multicolumn{3}{|c|}{ 3. ACCESS TO FINANCE } \\
\hline \multicolumn{3}{|l|}{ Access to Debt Financing } \\
\hline Country Credit Rating & The indicator is based on an assessment by the Institutional Investor Magazine Ranking. & IMD World Competitiveness Yearbook \\
\hline Domestic Credit to private sector & $\begin{array}{l}\text { The indicator refers to financial resources provided to the private sector - such as through } \\
\text { loans, purchases of non-equity securities, and trade credits and other accounts } \\
\text { receivable - that establish a claim for repayment. }\end{array}$ & $\begin{array}{l}\text { Published in World Development } \\
\text { Indicators, World Bank. Data are from } \\
\text { IMF's International Financial Statistics }\end{array}$ \\
\hline Ease of Access to Loans & $\begin{array}{l}\text { Survey responses to: how easy it is to obtain a bank loan in your country with only } \\
\text { a good business plan and no collateral ( } 1=\text { impossible, } 7 \text { = easy). }\end{array}$ & $\begin{array}{l}\text { World Economic Forum, } \\
\text { Global Competitiveness Report }\end{array}$ \\
\hline Interest Rate Spread & The lending rate minus deposit rate based on an average of annual rates for each country. & IMF, International Financial Statistics \\
\hline Legal Rights Index & $\begin{array}{l}\text { The degree to which collateral and bankruptcy laws facilitate lending. Higher scores } \\
\text { indicating that collateral and bankruptcy laws are better designed to expand access } \\
\text { to credit. }\end{array}$ & World Bank, Doing Business \\
\hline \multicolumn{3}{|l|}{ Access to Venture Capital } \\
\hline Venture Capital Availability & $\begin{array}{l}\text { Survey responses to: entrepreneurs with innovative but risky projects can generally } \\
\text { find venture capital in your country }(1=\text { not true, } 7=\text { true). }\end{array}$ & $\begin{array}{l}\text { World Economic Forum, } \\
\text { Global Competitiveness Report }\end{array}$ \\
\hline Venture Capital - Early Stage & $\begin{array}{l}\text { The level of investment performed by Venture Capital firms towards young businesses } \\
\text { in seed and start-up phases. }\end{array}$ & $\begin{array}{l}\text { OECD Entrepreneurship Indicators } \\
\text { Programme based on the following } \\
\text { sources: } \\
\text { ABS: Australian Bureau of Statistics } \\
\text { EVCA: European Private Equity and venture } \\
\text { Capital Association } \\
\text { VEC: Venture Enterprise Center } \\
\text { KVCA: Korean Venture Capital Association } \\
\text { NZVCA: New Zealand Venture Capital } \\
\text { Association }\end{array}$ \\
\hline
\end{tabular}


Table B.1. Indicators of entrepreneurial determinants and data sources (cont.)

\begin{tabular}{lll}
\hline Category of determinants & Definition & Data sources \\
\hline Venture Capital - Expansion Stage & $\begin{array}{l}\text { The level of investment performed by the VC sector for young firms in an expansion } \\
\text { phase (the phase following the seed and start-up phase). }\end{array}$ & OECD Entrepreneurship Indicators \\
& & Programme based on the following \\
sources: & ABS: Australian Bureau of Statistics \\
& & EVCA: European Private Equity and venture \\
& Capital Association & VEC: Venture Enterprise Center \\
KVCA: Korean Venture Capital Association & NZVCA: New Zealand Venture Capital & Association
\end{tabular}

Stock Markets

Buyouts

Capitalisation of Primary Stock Market

Capitalisation of Secondary Stock

Market

Investor Protection

Market Capitalisation of Newly Listed Companies

Turnover in Primary Stock Market
Transactions in which a business, business unit or company is acquired from the current shareholders.
OECD Entrepreneurship Indicators Programme based on the following sources:

ABS: Australian Bureau of Statistics EVCA: European Private Equity and venture Capital Association

VEC: Venture Enterprise Center KVCA: Korean Venture Capital Association NZVCA: New Zealand Venture Capital Association

World Federation of Exchange

The capitalisation of the primary stock market (the value of the issued shares on the market) relative to GDP.

An assessment of the efficiency of stock markets providing finance to companies. Ranking IMD World Competitiveness Yearbook goes from 1 (worst) to 10 (best).

The main indicators include: transparency of transactions (Extent of Disclosure Index), World Bank, Doing Business liability for self-dealing (Extent of Director Liability Index), shareholders' ability to sue officers and directors for misconduct (Ease of Shareholder Suit Index), strength of Investor Protection Index (the average of the three index).

The market capitalization (total number of new shares issued multiplied by their value on the first day of quotation) of newly listed domestic shares relative to GDP. The total shares traded on the stock market exchange in percentage of GDP.

World Federation of Exchange

World Bank and Standard and Poor's Emerging Market Database

4. CREATION AND DIFFUSION OF KNOWLEDGE

\section{R\&D Activity}

Business Expenditure on R\&D - BERD

Government Expenditure on R\&D -

GERD

Higher Education Expenditure on R\&D HERD

International Co-operation Between Patent Applications at PCT

Patents Awarded Based on Inventors Residence

Private Funding of R\&D Activity

Public Funding of R\&D Activity

Transfer of Non-commercial Knowledge

Research in Higher Education Sector Financed by Business

Share of Patents Owned by Universities

Universities or other Public Research Organizations as Source of Innovation

University/Industry Research Collaboration

Co-operation Among Firms

SMEs Stating Co-operation as the Source of Innovation
OECD Science and Technology Statistics OECD Science and Technology Statistics

OECD Science and Technology Statistics

The indicator measures international co-operation between patent applications under the Patent Cooperation Treaty (PCT). The measure is calculated as a percentage of total patents (by application date).

Number of patents awarded to inventors based on their residence. The indicator is a sum OECD Science and Technology Statistics of patents awarded by the European Patent Office (EPO) and US Patent and Trademark Office (USPTO)

Total private founded R\&D investments, independent of where the founding is spent. The indicator is measured as a percentage of GDP.

Total public funding of R\&D - as a percentage of GDP.

OECD Science and Technology Statistics

OECD Science and Technology Statistics

$R \& D$ expenditure performed at higher education and funded by business, measured as a percentage of total research expenditure.

The percentage of patents owned by universities. Only countries/economies with more than 300 patents are included.

The share of innovative enterprises that states universities or other PROs as an important Eurostat, European Community Innovation source of innovation.

Survey (CIS)

Survey responses to: the level of collaboration between business and universities in R\&D. World Economic Forum,

(1 for minimal or nonexistent to 7 for intensive and ongoing).

Global Competitiveness Report

The share of innovative small and medium sized enterprises (SMEs) stating any type of co-operation as the source of innovation.
Eurostat, European Community Innovation Survey (CIS) 
Table B.1. Indicators of entrepreneurial determinants and data sources (cont.)

\begin{tabular}{|c|c|c|}
\hline Category of determinants & Definition & Data sources \\
\hline \multicolumn{3}{|l|}{ Technology availability and take-up } \\
\hline Turnover from e-Commerce & $\begin{array}{l}\text { Total internet sales over the last calendar year, excluding VAT, as a percentage } \\
\text { of total turnover. }\end{array}$ & Eurostat, Information Society Statistics \\
\hline Enterprises Using e-Government & $\begin{array}{l}\text { The share of enterprises using any eGovernment services. The measure is based } \\
\text { on all firms with } 10 \text { employees or more, excluding the financial sector. }\end{array}$ & Information Society Statistics \\
\hline ICT expenditure & Expenditure for ICT equipment, software and services as a percentage of GDP. & $\begin{array}{l}\text { European Information Technology } \\
\text { Observatory (EITO) }\end{array}$ \\
\hline ICT expenditure in Communications & $\begin{array}{l}\text { Expenditure for telecommunications equipment and carrier services as a percentage } \\
\text { of GDP. }\end{array}$ & $\begin{array}{l}\text { European Information Technology } \\
\text { Observatory (EITO) }\end{array}$ \\
\hline \multicolumn{3}{|c|}{ 5. ENTREPRENEURIAL CAPABILITIES } \\
\hline \multicolumn{3}{|c|}{ Business and Entrepreneurship education (skills) } \\
\hline $\begin{array}{l}\text { International Students in Tertiary } \\
\text { Education }\end{array}$ & The share of international students in total tertiary enrolments. & OECD Education at a Glance \\
\hline Population with Tertiary Education & $\begin{array}{l}\text { The share of persons between } 25-34 \text { of age with tertiary-type B education or tertiary-type } \\
\text { A education and advanced research programmes. }\end{array}$ & OECD Education at a Glance \\
\hline Quality of Management Schools & $\begin{array}{l}\text { Survey responses to: the quality of management schools across Countries is } \\
\text { (limited or of poor quality for } 1 \text {, to amongst the best in the World for } 7 \text { ). }\end{array}$ & $\begin{array}{l}\text { World Economic Forum, } \\
\text { Global Competitiveness Report }\end{array}$ \\
\hline $\begin{array}{l}\text { Received Training in Starting a Business } \\
\text { During School }\end{array}$ & $\begin{array}{l}\text { The percentage of the population aged } 18-64 \text { that received training - voluntary } \\
\text { or compulsory - in starting a business during school. }\end{array}$ & $\begin{array}{l}\text { Global Entrepreneurship Monitor (GEM) } \\
2008 \text { Executive Report }\end{array}$ \\
\hline $\begin{array}{l}\text { Received Training in Starting a Business } \\
\text { After School }\end{array}$ & $\begin{array}{l}\text { the percentage of the population aged 18-64 that received training - voluntary } \\
\text { or compulsory - in starting a business after school. }\end{array}$ & $\begin{array}{l}\text { Global Entrepreneurship Monitor (GEM) } \\
2008 \text { Executive Report }\end{array}$ \\
\hline \multicolumn{3}{|l|}{ Immigration } \\
\hline Inflows of foreign labour & Inflows of foreign workers as a percentage of the total labor force. & OECD International Migration Outlook \\
\hline Migrants with Tertiary Education & The share of highly skilled migrants as a percentage of total migrants. & $\begin{array}{l}\text { OECD, A profile of immigrant populations } \\
\text { in the } 21 \text { st century. Database on } \\
\text { immigrants in OECD countries (DIOC) }\end{array}$ \\
\hline Self-employment by Place of Birth & $\begin{array}{l}\text { The share of self-employment by foreign-born persons. Self-employment is measured } \\
\text { as a percentage of total employment. }\end{array}$ & OECD International Migration Outlook \\
\hline Stocks of foreign labour & The stock of foreign workers as a percentage of the total labor force. & OECD International Migration Outlook \\
\hline \multicolumn{3}{|c|}{ 6. ENTREPRENEURSHIP CULTURE } \\
\hline Desirability of Becoming Self-Employed & $\begin{array}{l}\text { Survey responses to: desire to become self-employed within the next } 5 \text { years. } \\
\text { This question was asked only to non-self-employed individuals. }\end{array}$ & $\begin{array}{l}\text { European Commission, } \\
\text { Flash Eurobarometer }\end{array}$ \\
\hline Entrepreneurial Intention & $\begin{array}{l}\text { The percentage of } 18-64 \text { population (individuals involved in any stage of entrepreneurial } \\
\text { activity excluded) who intend to start a business within three years. }\end{array}$ & $\begin{array}{l}\text { Global Entrepreneurship Monitor (GEM) } \\
2009 \text { Executive Report }\end{array}$ \\
\hline Entrepreneurial Motivation & $\begin{array}{l}\text { The percentage of early stage entrepreneurs who were motivated by either a) a desire } \\
\text { for independence or } b \text { ) a desire to increase their income. }\end{array}$ & $\begin{array}{l}\text { Global Entrepreneurship Monitor (GEM) } \\
2007 \text { Executive Report }\end{array}$ \\
\hline Entrepreneurship among Managers & $\begin{array}{l}\text { How senior executives rank the level of entrepreneurship of business managers } \\
\text { in the given country from a scale of } 0 \text { to } 10 .\end{array}$ & IMD World Competitiveness Yearbook. \\
\hline Entrepreneurs are Job Creators & Survey responses. & $\begin{array}{l}\text { European Commission, } \\
\text { Flash Eurobarometer }\end{array}$ \\
\hline $\begin{array}{l}\text { Entrepreneurs Exploit other People's } \\
\text { Work }\end{array}$ & Survey responses. & $\begin{array}{l}\text { European Commission, } \\
\text { Flash Eurobarometer }\end{array}$ \\
\hline $\begin{array}{l}\text { Entrepreneurs is Basis for Wealth } \\
\text { Creation }\end{array}$ & Survey responses. & $\begin{array}{l}\text { European Commission, } \\
\text { Flash Eurobarometer }\end{array}$ \\
\hline $\begin{array}{l}\text { Entrepreneurs think only about their } \\
\text { Own Wallets }\end{array}$ & Survey responses. & $\begin{array}{l}\text { European Commission, } \\
\text { Flash Eurobarometer }\end{array}$ \\
\hline $\begin{array}{l}\text { Fear of Failure would prevent Starting a } \\
\text { Business }\end{array}$ & $\begin{array}{l}\text { the percentage of non-entrepreneurially active adult population aged 18-64 that sees good } \\
\text { opportunities to start a business, where fear of failure would prevent starting a business. }\end{array}$ & $\begin{array}{l}\text { Global Entrepreneurship Monitor (GEM) } \\
2008 \text { Executive Report }\end{array}$ \\
\hline Good Conditions to Start a Business & $\begin{array}{l}\text { The percentage of non-entrepreneurially active adult population aged 18-64 that sees } \\
\text { good opportunities for starting a business in the next } 6 \text { months. }\end{array}$ & $\begin{array}{l}\text { Global Entrepreneurship Monitor (GEM) } \\
2008 \text { Executive Report }\end{array}$ \\
\hline Image of entrepreneurs & $\begin{array}{l}\text { Survey responses to: image of entrepreneurs according to their status in society. } \\
\text { Entrepreneurs are ranked against civil servants and managers. }\end{array}$ & $\begin{array}{l}\text { European Commission, } \\
\text { Flash Eurobarometer }\end{array}$ \\
\hline Risk for Business Failure & Survey responses to: being willing to start a business if a risk exists that it might fail. & $\begin{array}{l}\text { European Commission, } \\
\text { Flash Eurobarometer }\end{array}$ \\
\hline "The Wish to Own one's Own Business" & Survey responses. & $\begin{array}{l}\text { European Commission, } \\
\text { Flash Eurobarometer }\end{array}$ \\
\hline \multicolumn{3}{|l|}{ Entrepreneurship education (mindset) } \\
\hline Self-Employment Preference & Survey responses to: preferences towards being self employed or being an employee. & $\begin{array}{l}\text { European Commission, } \\
\text { Flash Eurobarometer }\end{array}$ \\
\hline
\end{tabular}





\section{ORGANISATION FOR ECONOMIC CO-OPERATION AND DEVELOPMENT}

The OECD is a unique forum where governments work together to address the economic, social and environmental challenges of globalisation. The OECD is also at the forefront of efforts to understand and to help governments respond to new developments and concerns, such as corporate governance, the information economy and the challenges of an ageing population. The Organisation provides a setting where governments can compare policy experiences, seek answers to common problems, identify good practice and work to co-ordinate domestic and international policies.

The OECD member countries are: Australia, Austria, Belgium, Canada, Chile, the Czech Republic, Denmark, Estonia, Finland, France, Germany, Greece, Hungary, Iceland, Ireland, Israel, Italy, Japan, Korea, Luxembourg, Mexico, the Netherlands, New Zealand, Norway, Poland, Portugal, the Slovak Republic, Slovenia, Spain, Sweden, Switzerland, Turkey, the United Kingdom and the United States. The European Commission takes part in the work of the OECD.

OECD Publishing disseminates widely the results of the Organisation's statistics gathering and research on economic, social and environmental issues, as well as the conventions, guidelines and standards agreed by its members. 


\section{Entrepreneurship at a Glance 2011}

Entrepreneurship at a Glance is a new, recurrent publication that presents an original collection of indicators for measuring the state of entrepreneurship along with explanations of the policy context and interpretation of the data. This publication also includes special chapters that address measurement issues, and solutions, concerning entrepreneurship and its determinants. In this first issue the special topics covered are: business demography and green entrepreneurs.

This new publication is a product of the OECD-Eurostat Entrepreneurship Indicators Programme, which is a long-term programme of internationally-comparable policy-relevant entrepreneurship statistics. The work involves developing standard definitions and concepts and engaging countries and international Agencies in the collection of data. An international group of statisticians and analysts provides guidance to the Programme that benefits from sponsorship by the Ewing Marion Kauffman Foundation in the United States and the International Consortium for Entrepreneurship (ICE).

\section{Contents}

\section{Measuring entrepreneurship}

Entrepreneurship indicators and business registers: The importance of international comparability Measuring Green Entrepreneurship

\section{Entrepreneurship indicators}

Structural indicators on the enterprise population

Enterprise birth, death and survival

Employment creation and destruction

Enterprise growth

Timely indicators of entrepreneurship

Women entrepreneurship

Migrant entrepreneurship

Determinants of entrepreneurship: Selected indicators

Please cite this publication as:

OECD (2011), Entrepreneurship at a Glance 2011, OECD Publishing.

http://dx.doi.org/10.1787/9789264097711-en

This work is published on the OECD iLibrary, which gathers all OECD books, periodicals and statistical databases. Visit www.oecd-ilibrary.org, and do not hesitate to contact us for more information.

\section{1}

